\title{
Crowning the May Queen in Freshwater Place: Housing reformers and the uses of urban nature, 1850-1914
}

Christine E. Regier

West Virginia University

Follow this and additional works at: https://researchrepository.wvu.edu/etd

\section{Recommended Citation}

Regier, Christine E., "Crowning the May Queen in Freshwater Place: Housing reformers and the uses of urban nature, 1850-1914" (2013). Graduate Theses, Dissertations, and Problem Reports. 4994.

https://researchrepository.wvu.edu/etd/4994

This Thesis is protected by copyright and/or related rights. It has been brought to you by the The Research Repository @ WVU with permission from the rights-holder(s). You are free to use this Thesis in any way that is permitted by the copyright and related rights legislation that applies to your use. For other uses you must obtain permission from the rights-holder(s) directly, unless additional rights are indicated by a Creative Commons license in the record and/ or on the work itself. This Thesis has been accepted for inclusion in WVU Graduate Theses, Dissertations, and Problem Reports collection by an authorized administrator of The Research Repository @ WVU. For more information, please contact researchrepository@mail.wvu.edu. 


\title{
Crowning the May Queen in Freshwater Place: Housing reformers and the uses of urban nature, 1850-1914
}

\author{
Christine E. Regier \\ Thesis submitted to the \\ Eberly College of Arts and Sciences \\ at West Virginia University \\ in partial fulfilment of the requirements \\ for the degree of \\ Master of Arts \\ in \\ History
}

Dr Joseph M. Hodge, Chair

Dr Robert Blobaum

Dr Joshua Arthurs

Department of History

Morgantown, West Virginia

2013

Keywords: European history, urban history, environmental history, nature, London, housing, slums, model dwellings, Garden Suburbs, political economy, political ecology, open spaces, George Godwin, Octavia Hill, Henrietta Barnett

Copyright 2013 Christine E. Regier 


\begin{abstract}
Crowning the May Queen in Freshwater Place:

Housing reformers and the uses of urban nature, 1850-1914
\end{abstract}

Christine E. Regier

Ideas about nature change over time, yet the term is often used as though its meaning were universal. This study of the uses of nature in working-class housing reform in Victorian and early twentieth-century London deconstructs concepts of nature to reveal the social and cultural norms on which these concepts rely. The first efforts to provide sanitary housing to replace the London slums began in the 1840s. Model dwellings companies built housing blocks designed to give the poor access to three natural resources important in sanitation: clean water, fresh air and sunlight. They operated on a model of commercial philanthropy, that is, aiming to provide a social benefit while turning a modest profit. This, they believed, would prevent their efforts from causing harm by distorting the working of the free market, which they perceived as a system of natural laws. These ideas are investigated through the writing of architect and model dwellings advocate George Godwin, as well as other writers and activists. Octavia Hill, an important contributor to the housing movement and a pioneer in nature conservation, was deeply committed to an idea of nature as a source of truth and beauty, inspired in large part by the influence of John Ruskin. This concept of nature was rich in ideas about community and society that are explored in chapter two. Hill's collaborator in the 1870 s, Henrietta Barnett, would go on to found the Hampstead Garden Suburb in the early twentieth century. The suburb was one of the first developments inspired by Garden City ideals. Barnett believed that the division of classes into separate residential areas in cities was artificial. This conviction led her to create a space that not only incorporated green space, gardens and trees, but was intended to produce natural, friendly relationships between people of different classes. In all these endeavours an underlying understanding of the city as the antithesis of nature led reformers to attempt to reintroduce nature to the urban environment in order to cure the moral and physical ills of the slums. 


\section{Table of Contents}

$\begin{array}{ll}\text { Introduction } & 1\end{array}$

Chapter 1: "Shall we then counteract so wise a dispensation?" Nature, political 20 economy and efforts to purify slum dwellings in the 1850 s and 1860 s

Chapter 2: "Bits of God's Earth:" The concept and uses of nature in Octavia 56 Hill's social housing and conservation work

Chapter 3: "Unwalled Roses in the Streets:" Henrietta Barnett and the 88 Hampstead Garden Suburb

Conclusion 
Introduction 
Running feet in worn boots churn the gravel surface of the little playground. The children's clothes are unkempt and the colourful floral wreaths they wear in their tousled hair slip askew as they play under the gaze of the crowd of adults. Cheerful music drifts up to neighbours watching from upper-story windows. A few barefoot boys have let their flowers fall as they enjoy their cake and oranges in a corner. The friends and patrons of Freshwater Place, in the working-class London parish of Marylebone, have been busy with preparations. Miss Emily Hill and her pupils worked all evening to create wreaths and a flowery throne for the poor children, made from plentiful blossoms sent by the landlord, Mr Ruskin. Then, as the assembled guests gathered with the tenants that May morning in 1868, Miss Florence Hill opened the ceremony by drawing lots for the May Queen, and directing the chosen girl's distribution of wreaths and treats. Now the recipients revel together as residents and their better-dressed well-wishers converse politely, some even joining in the games. Young Nelly Kinaly, queen for a day, laughs with her friends; these grubby London children in their untidy clothes are made picturesque, say the approving ladies, by the posies they wear.

It is only three years since Miss Octavia Hill - absent today due to illness - took on the management of Freshwater Place. Some of the tenants milling around are the same Miss Hill described at the time as "a desperate and forlorn set of people, wild, dirty, violent and ignorant as I have ever seen," although those who preferred not to be reformed by the new régime have left or been evicted. They remember the dilapidated stables that stood where the children now play, the tenants who once crowded into the filthy, ill-kept buildings now converted into warehouses. Middle-class supporters of Miss Hill's work 
remember being warned by a policeman not to enter such a dangerous court. But her efforts have changed this small fragment of the cityscape. As the years pass, the slim saplings and creepers that dot the grey courtyard will grow, and the May Queen festival will be held annually in the little playground that Miss Hill worked so hard to procure for her tenants. ${ }^{1}$

Did it seem strange to any of the participants that a small and unlovely corner of the metropolis should adopt a tradition born of the yearly rhythms of agrarian labour? Did the little trees planted by the gravel playground seem out of place in such an unappealing neighbourhood, or the wreaths of flowers unsuited to pale urban children? As with many instances of Victorian philanthropy, this meeting of two classes is somewhat uneasy; the middle classes bringing material benefits but also expectations, the working classes accepting or resisting the obligations that the gifts entail, and the ever present, yet unspoken question of the just distribution of the rewards of industry. Certainly, as Jan Marsh notes, there is a deep irony in the revival of the May festival, which became more widely popular by the 1890s: "what had been a popular tradition maintained in defiance of parson and squire became an event promoted by these same authorities" ${ }^{2}$ - although this refers to rural settings. Anthony Wohl goes further, finding "something ludicrous" about the Marylebone event: "who but Miss Hill would pursue,

\footnotetext{
${ }^{1}$ My account is imagined from several letters to and from Octavia Hill about Freshwater Place, as well as some reminiscences, collected in Octavia Hill and C. Edmund Maurice, Life of Octavia Hill as Told in Her Letters (London: Macmillan and Co., Limited, 1913), 192; 221; 244-5; 250; the direct quotation is from 221. See also Emily Southwood Maurice, Octavia Hill: Early Ideals, from Letters (London: George Allen and Unwin, 1928), 197. Emily and Florence were Octavia Hill's younger sisters. The May Queen festival was celebrated in Freshwater Place for two decades.

${ }^{2}$ Jan Marsh, Back to the Land: The Pastoral Impulse in Victorian England, 1880-1914 (London: Faber and Faber, 2010, first published 1982), 12.
} 
amid such dreary and depressing surroundings, the notion of a maypole, complete with may queen and throne adorned with flowers?" ${ }^{3}$ There is more to this sense of incongruity than the clash of worldviews involved in the meeting of two classes. Why, after all, should a May Queen in a slum seem such a ridiculous idea to a twentiethcentury commentator? The reaction reveals as much about the historian as about his subject. It draws on a deep current in Western thought that sees cities as the antithesis not only of rural life, but of nature itself.

This thesis will investigate how interwoven ideas about cities and about nature were expressed in the writings and actions of the Victorian reformer, Octavia Hill, and some of her predecessors and associates, as they attempted to tackle a pressing urban social problem: the provision of appropriate housing for the urban poor. It will argue that their conceptions of nature contained a multitude of social and cultural norms which shaped and constrained their uses of natural resources and green spaces. Furthermore, these reformers presumed that their ideas of nature were fixed and universal. Thus, their schemes, which relied upon nature as a force for improvement, contained social imperatives and political agendas but presented themselves as beyond controversy or debate.

To define the term nature is a complex endeavour, yet the word is often used as though its meaning were self-evident and unchanging. However, competing discourses have frequently appealed to nature as a model for normative social behaviour, or to legitimate

\footnotetext{
3 Anthony Wohl, The Eternal Slum: Housing and Social Policy in Victorian London (Montreal : McGillQueen's University Press, 1977), 193.
} 
political systems. Jean-Jacques Rousseau, for example, found Paris unnatural in part because women took a more public role there than in rural France; social Darwinists in the late nineteenth century appealed to nature to justify the disenfranchisement and exploitation of certain racial groups. ${ }^{4}$ In twenty-first-century Western culture such ideas no longer contribute to a widely-accepted conception of nature. Yet nature still tends to be viewed as unchanging: a serenely stable counterpoint to a rapidly changing social world; an example to and a respite from our own restlessness and disharmony. It may be difficult, then, to conceptualise the idea of nature as itself constantly shifting from culture to culture and from age to age.

One way of defining a word that signifies a complex concept is to study its antonyms. ${ }^{5}$ Nature has many, including artifice and civilisation, both of which are epitomised by cities. Industrial cities, especially, have been viewed as the antithesis of nature: "Vast herds of human beings are penned into small areas from which nature is excluded...man has carved out for himself new and artificial conditions;" wrote Charles Masterman in 1901, while Lewis Mumford sixty years later denounced the industrial city as "a blasted, de-natured man-heap." ${ }^{6}$ David Harvey's more recent declaration that, in fact, "there is

\footnotetext{
${ }^{4}$ For Rousseau, see for example Ronald Grimsley, "Rousseau's Paris," in City and Society in the 18th Century, ed. Paul Fritz and David Williams, 3-18 (Toronto: Hakkert, 1973); for the use of Darwin's theories to justify British hegemony in Ireland, see Michael de Nie, The Eternal Paddy: Irish Identity and the British Press, 1798-1882 (Madison: University of Wisconsin Press, 2004), 8-13.

5 Raymond Williams did so particularly well for nature in Keywords (New York: Oxford University Press, 1976), 184-189; George Boas also deploys antonyms to define the concept of nature in his useful essay in the Dictionary of the History of Ideas, ed. Philip P. Wiener (New York: Charles Scribner's Sons, 1973), III: 346-351.

${ }^{6}$ C. F. G. Masterman, The Heart of the Empire: Discussions of Problems of Modern City Life (London: T. Fisher Unwin, 1901), v; Lewis Mumford, The City in History: Its Origins, its Transformations, and its Prospects (San Diego: Harcourt Inc., 1961), 453.
} 
nothing unnatural about New York City" 7 jars uncomfortably with current notions of nature, and with ideas about sustainability, conservation, and environmental politics.

If the city is seen as the antithesis of nature, then the way we understand and live in cities, and represent them to ourselves, has a profound impact on our concept of nature, and vice versa. Deconstructing ideas of nature can provide a useful tool for understanding urban questions and realities in history. By investigating some Victorian ideas about nature, this thesis will shed light on one urban question that was extensively debated at the time: the problem of providing decent working class housing in London.

\section{Nature and the "Housing Question"}

British cities had been growing, increasingly rapidly, for several decades by 1832 . In this year, a cholera epidemic swept through cities in Europe and North America, killing thousands of people. Although the victims belonged to all classes, the disease was particularly associated with the squalid conditions of working-class streets. The epidemic spurred political leaders to act. In Britain by the 1840s, reformers led by Edwin Chadwick had persuaded Parliament to pass the first public health legislation. The work of the 1840 s focussed primarily on sanitary problems, especially the provision of sewers and clean water, and despite being based on erroneous miasmatic theories of disease transmission the measures had overall a very positive effect on health. ${ }^{8}$

\footnotetext{
7 David Harvey, Justice, Nature and the Geography of Difference (Oxford: Blackwell Publishers, 1996), 186.

${ }^{8}$ Miasmatic theory held that miasmas, that is, gases and particles emanating from decaying organic matter, were responsible for imparting diseases to human beings.
} 
Chadwick's campaign had brought to light the filthy and miserable conditions in the homes of the poor. Yet it now became evident that good drainage alone would not suffice to remedy them. In London, the working-class housing tended to be situated around courts and in back alleys, sometimes right next to, but hidden from, the rows of prestigious homes on more fashionable streets. Exploration of the "rookeries" or slums spawned a vast brood of articles, books and sermons. ${ }^{9}$ Victorian writers laboured to transform a shocking, unacceptable, incomprehensible phenomenon into a set of problems that could be addressed in practical ways. The degraded environments no doubt caused slum inhabitants daily stress, as they tried to keep their families fed, warm, sheltered and healthy on wages that too often could not stretch to rent even a single room per family; the psychological stress of living in such close quarters must also have been considerable. The middle- and upper-class writers who problematised the slums in the 1830 s and 1840 s had other concerns. They associated physical dirt with immorality, and feared that not only disease, but also crime and social unrest, would spread from the wretched courts. These concerns shaped a discourse about the dwellings of the urban working classes which outlined what appropriate responses should be. ${ }^{10}$

\footnotetext{
9 The idea that working-class spaces were hidden from, or illegible to, middle-class city-dwellers, was a prominent theme in writing about Paris too. See for example Victoria Thompson, "Telling "Spatial Stories": Urban Space and Bourgeois Identity in Early Nineteenth-Century Paris," The Journal of Modern History 75:3 (September 2003).

${ }^{10}$ Many elements of this discourse were common to all large Western cities. Writers from the industrialising nations of Europe and North America visited each other's cities and reported back on the conditions and the successes and failures of reform measures there. For a Belgian and English example, see Janet Polasky, "Transplanting and Rooting Workers in London and Brussels: A Comparative History," The Journal of Modern History 73:3 (September 2001): 528-560.
} 
One avenue by which to tackle urban problems was to improve housing conditions for working people. By the late 1840 os a few housing associations had sprung up in London to build model housing for labouring families. These were motivated chiefly by philanthropic concern, but were organised as commercial businesses, paying their shareholders a small but stable dividend, so as to encourage further investment. Such model dwellings companies dominated the field of social housing until 1890, when local governments gained the authority to build housing for the local poor. The companies strove to offer both good sanitary facilities and enough space to encourage a "respectable" level of privacy. However, they would constantly struggle to balance this desire with the imperative to make a profit while keeping rents affordable. ${ }^{11}$

As land rents rose in central London in the 1850 s the model dwellings companies had to reduce their activity, which in any case had been on such a small scale as to make virtually no difference to the metropolitan housing market. However during this decade writers such as the architect George Godwin continued to draw attention to the appalling conditions of the slums and the possibilities offered by model dwellings. By the 1860s new efforts were being made. As Parliament passed piecemeal and permissive legislation that allowed, but did not force, local councils to clear slums and encourage new building, new model dwellings companies arose and experimented with a variety of plans, attempting to balance cost with amenities.

\footnotetext{
${ }^{11}$ The model of commercial philanthropy was also tried in Paris: see Marie-Jeanne Dumont, Le logement social a Paris 1850-1930: Les habitations à bon marché (Liege: Mardaga, 1991), 9-11. The upheavals caused by Haussmann's massive restructuring of Paris, and then by the Franco-Prussian war and the Paris Commune, limited the scope of such projects.
} 
In this decade Octavia Hill began her career as a housing manager and advocate. She believed that not only the homes of the poor, but the poor themselves, needed to be reformed. Her method was to take on existing buildings, repair them to a basic standard of cleanliness, and embark on a programme of training the inhabitants to keep both their homes and their families in a state she deemed respectable. She did this through personal contact and close supervision by a team of middle- or upper-class, female rentcollectors. But Hill also brought to the housing movement an emphasis on the mental and emotional needs of tenants. She believed that sanitary dwellings need not be sterile and ugly; beauty, colour, and space should be encouraged. She is particularly known for her campaigns for the preservation of green space in urban settings. ${ }^{12}$

By the 1870 interest in the "housing question" was growing. In the 1880 os a mounting frustration among the interested public with the inefficacy and unwieldiness of the existing legislation on housing led to a flurry of new writing. By now some of the most powerful men in the nation had taken an interest in the question, including Joseph Chamberlain and the Marquis of Salisbury. Public opinion in Britain, meanwhile, left behind its rigid adherence to laissez-faire and recognised a need for greater state intervention in matters of health and well-being, and this opened the way for local councils to provide working-class housing. The London County Council was created in

\footnotetext{
${ }^{12}$ Again, this was not unique to England. The work of Frederick Law Olmsted in the United States is particulary well-known. For an account of his work on New York's Central Park, see Matthew Gandy, Concrete and Clay: Reworking Nature in New York City (Cambridge, Mass. and London: The MIT Press, 2002)
} 
1888 and almost immediately began to develop its own estates on cleared sites that philanthropic organisations had not been able to afford.

As the nineteenth century gave way to the twentieth, Ebenezer Howard published his first books about the Garden City, an important new development in the housing movement. Howard was a Parliamentary reporter who had long taken an interest in reform ideas, both in England and during a brief period living in the United States. Inspired by decades of experiments with model villages, and weaving together ideas about cities, nature, housing and society that had been debated in the preceding years, Howard proposed a solution to problems of high rent and long commutes. The Garden City would be a planned community, combining the employment opportunities and cultural stimulation of the city with low-density housing and the preservation of natural or green spaces. Many of those involved in the Garden City movement were also active in the growing field of town planning. In the years before the First World War a number of developments were begun, from the First Garden City at Letchworth to a number of smaller residential projects, one of which was the Hampstead Garden Suburb. Henrietta Barnett, who had begun her career as one of Octavia Hill's rent-collectors, was the driving force behind this project, begun in the first years of the twentieth century.

Ideas about cities and about nature were constantly deployed in the Victorian housing movement, from its beginnings in sanitary reform to the garden suburbs of the Edwardian era. Before solutions could be proposed for the terrible conditions of the 
urban slums, the problem itself had to be defined and the lines of the debate sketched out. The conception of cities - and slums in particular - as artificial or unnatural was an important step in the process of problematising the issue. Therefore, deconstructing housing reformers' ideas of nature, and explaining why, how, and where they drew the line between nature and the city, can help us understand their actions and the spaces they created. It can also show how their ideas of nature could allow them to adhere to worldviews or political positions that might otherwise contradict each other.

\section{Cities, Nature, and Environmental History}

It follows, then, that when historians write about nature and its influence on human actions and thought, it is imperative that they first pause and consider what is meant by the word. One may view nature as created by God or the product of evolutionary processes, ${ }^{13}$ one may see it as including or separate from humans and their culture, a threat to human life or threatened by human activities. According to these attitudes one defines what is and is not natural, assigns value to nature, and deems certain human interactions with nature appropriate or desirable. Octavia Hill was a well-read Victorian Englishwoman who espoused the Christian faith, who spent her childhood in a country village and most of her adult life in London. Her "nature" is not the "nature" of, for example, her American contemporary, the wilderness advocate John Muir, ${ }^{14}$ who elected to live a spartan and almost solitary existence in the grandly beautiful Californian Sierra. Still less is it the "nature" of the twenty-first century, shaped by the environmental

\footnotetext{
${ }^{13}$ Or, indeed, both: the two are not necessarily mutually exclusive.

14 Both were born in 1838 .
} 
activism of the 1960 s and 1970 s and tied up with such phenomena as climate change, biodiversity, ecotourism or the locavore movement. "The idea of nature," wrote Raymond Williams, "contains, though often unnoticed, an extraordinary amount of human history." ${ }^{15}$ For this reason nature, as William Cronon argues, must be "a fundamental category of historical analysis, no less important than - indeed, deeply entangled with - class, race and gender." ${ }^{16}$

The meaning of nature differs, then, over time and between cultures. Today's environmental historians treat nature as a category of analysis and indeed as an historical actor, affected by human actions but also shaping human choices, economies, societies and cultures. Their work perforce reflects the aspects of nature most salient to them as individuals, and rooted in their own cultural, political and social values.

Environmental history has to date been dominated by American themes, since that is where the field as it is today was born. It was conceived in the environmental movement, and many of its chief practitioners were also environmental activists. ${ }^{17}$ The concept of nature deployed in these historians' work has therefore been determined by American thinking on nature, generated by the particularities of the American landscape through

\footnotetext{
15 Raymond Williams, "Ideas of Nature," in Problems in Materialism and Culture (London: Verso, 1980), 67.

${ }^{16}$ William Cronon, “The Uses of Environmental History,” Environmental History Review 17:3 (Fall 1993), 1-22

${ }^{17}$ J. Donald Hughes, What is Environmental History? (Cambridge, UK: Polity Press, 2006), 36-42.
} 
the nation's history. ${ }^{18}$ In particular, environmental activists and historians have often equated nature with wilderness and considered man-made landscapes, whether urban or rural, as falling outside the category of nature. European-Americans originally enshrined wilderness as a core value because they chose to understand the continent on which they settled as empty and untouched by civilisation. ${ }^{19}$

Historians of Great Britain appear to have been latecomers to the field, to the extent that one commentator questions whether it is even possible to speak of a "British Environmental History.” ${ }^{20}$ However, there is a long tradition of landscape history, which together with historical geography has covered much of the same subject matter, although approaching it with different sensibilities. The main difference between the British historiography and the newer American work, remarks Matt Osborn, has been "lack of an explicit critical stance," and more emphasis on description, especially in work done before the 1990s. ${ }^{21}$ If there has been a current of anti-modernism and antiurbanism in landscape history, there has not been the same focus on wilderness as in America: it is many centuries since any inhabitants of Britain could see their island as

\footnotetext{
${ }^{18}$ Sverker Sörlin and Paul Warde list "a low population density, large stretches of 'wilderness,' a mobile 'frontier,' and a strong tradition of the 'outdoors' "“. "The Problem of the Problem of Environmental History: A Re-reading of the Field.” Environmental History 12, no. 1 (January 2007): 109.

${ }^{19}$ For a critique of this unexamined prizing of wilderness, see Cronon, "Trouble." For the blind spot of early wilderness advocates regarding Native Americans' connection to the land, see Susan Schrepfer, Nature's Altars: Mountains, Gender, and American Environmentalism (Lawrence, Kansas: University Press of Kansas, 2005).

${ }^{20}$ Timothy Cooper, "British Environmental History," article on the Making History site of the University of London's Institute of Historical Research, n. d. (but after 2007). Available from: http:// www.history.ac.uk/makinghistory/resources/articles/environmental history.html
}

${ }^{21}$ Matt Osborn, "Sowing the Field of British Environmental History," H-Net Environment Group discussion paper, 2001. Available from: www.h-net.org/ environ/historiography/british.htm. Sörlin and Warde think that historical geographers may begin to "re-brand" themselves as environmental historians without radically changing their research focus: Sörlin and Warde, "Problem of the Problem," 110. 
empty. The landscape is a palimpsest, where succeeding generations inscribe new meanings on the territory. Emily Brontë's windswept moors were once ancient forest, yet the undeniable imprint of human activity does not disqualify them as an aptly wild setting for her romantic fantasy.

A space may, then, be categorised as "natural" when it is managed or even cultivated by humans. Still, neither British nor American historians have considered, until quite recently, that an urban space might be seen as a natural one, and therefore a fit subject for environmental history. In the mid-twentieth century, the influential urbanist Lewis Mumford wrote that cities replaced natural landscapes with spaces that were not merely artificial, but "a definitely antiorganic environment;" large cities were "parasites" on nature. ${ }^{22}$ Parasitism is, however, an organic relationship; Mumford's choice of metaphor implies that the city is still part of an ecosystem. Historians who combine the subfields of environmental and urban history argue that human systems are inextricable from natural processes. To see cities as separate from nature belies both their dependence and their impact on their physical site as well as their hinterlands (whether nearby or, in our global economy, much further afield). ${ }^{23}$

\footnotetext{
${ }^{22}$ Lewis Mumford, “The Natural History of Urbanization," in Man's Role in Changing the Face of the Earth, ed. William L. Thomas, Jr., (Chicago and London: University of Chicago Press, 1956), 391.

23 One North American example: William Cronon's Nature's Metropolis: Chicago and the Great West (New York and London: Norton, 1991) was the pioneer environmental history of a city and its hinterland; it influenced and inspired the field of urban environmental history. Sörlin and Warde deplore the continuing lack of urban and suburban themes in environmental history: Sörlin and Warde, "Problem of the Problem" (109).
} 
Environmental histories of British cities have tended to focus on air and water pollution, and on public health measures, with more recent studies highlighting the role of technology as an interface between humans and nature. ${ }^{24}$ Octavia Hill is a central figure in this study because her work is a point of connection between the environmental problems of the Victorian city and nature conservation - between newer and older threads of British historiography - and shows how the same understanding of nature informed both spheres.

\section{Urban Political Ecology}

Urban environmental historians have been criticised for "downplaying, in some cases ignoring, the importance of urban political economy." ${ }^{25}$ By using the theories and arguments of urban political ecology this thesis aims to address this issue. Political ecology seeks to expose the ways in which social and political systems and processes interact with ecological ones. Political ecologists come from a number of disciplines in the natural and social sciences, and defining the field is not simple; however, they share a set of fundamental questions. Scholars investigate how political and institutional configurations give certain groups power to transform land and ecosystems in ways that benefit them, while constraining other groups' choices. They study the distribution of environmental benefits and costs among different human actors. Above all, they challenge apolitical ecologies by working “to ‘denaturize' certain social and environmental conditions, showing them to be the contingent outcomes of power, and not inevitable." ${ }^{26}$ They deconstruct discourses about nature that - often deliberately -

\footnotetext{
${ }^{24}$ Osborn, Sowing the Field.

${ }_{25}$ Nik Heynen, "Green urban political ecologies: toward a better understanding of inner-city environmental change," Environment and Planning A, 38 (2006): 501.

${ }^{26}$ Paul Robbins, Political Ecology: A Critical Introduction (Malden, MA: Blackwell, 2004), 12
} 
obscure the political choices and stances that underpin them, presenting themselves as universal, inevitable or normative. Malthusian ideas about population growth, for example, posit famine as nature's way of reducing the poor-rates, the inevitable consequence of high birth rates among the poor, thus avoiding questions about the just distribution of wealth. Many political ecologists write from a Marxist or Marxian perspective, seeking to expose the contradictions and tensions inherent in the ideology and workings of capitalism. Others, less committed to a particular ideology, tend to focus on issues of social justice as they interact with ecology.

Like urban environmental history, urban political ecology (UPE) is a relatively new area of interest in the field. Most of the early work in political ecology focussed on rural areas in the global South. Researchers noted that discourses about wildlife preservation and environmental protection either erased human activity from the landscape or blamed the poor for ecological destruction. Such discourses could actually enable social injustice in the name of conservation. Urban political ecologists have drawn attention to the unequal distribution of environmental benefits in cities. Like urban environmental historians they have argued that viewing cities as separate from nature is both erroneous and harmful; the city/nature binary allows, for example, wilderness areas to be prized as pristine while pollution is seen as so endemic to urban working-class neighbourhoods that it is part of their identity, and therefore not addressed.

This study will contribute a historical perspective to UPE by showing how ideas about nature and cities evolved in nineteenth-century Britain. As UPE would predict, these ideas were intimately tied to the dominance and decline of laissez-faire political economy. Chapter one, in particular, will investigate this connection.

\section{Conclusion}


It is important, then, when investigating the ways in which historical subjects wrote about nature or interacted with landscapes that they deemed natural or artificial, to make nature itself the object of inquiry. When George Godwin, or Octavia Hill, or Henrietta Barnett wrote about nature, what exactly did they mean by the term? How did their conceptions of nature reflect their own class, gender, and nationality, or their professional and political identities? How did their ideas of nature determine the ways in which they interacted with working-class people? How did invoking nature give them power to shape urban spaces? I am particularly interested in those reformers who were women and men of action rather than systematic thinkers. Like many twenty-first century ecological advocates, they used the concept of nature as a powerful idea without submitting it to close examination or rigorous definition. However, failing to articulate the political position that underpins a particular idea of nature does not mean that the discourse is apolitical. This thesis will seek to uncover the political positions and social norms that underlie the discourse and actions of these housing reformers.

Chapter one will focus on the 1850 os and 1860 s, a time when classical economic theory held sway in both public opinion and government policy in the form of laissez-faire political economy, and when reformers and officials were deeply concerned with sanitation and public health in large cities. It will use, primarily, the writings of George Godwin to shed light on the ideas about nature that underlay the work of the model dwellings companies. Both sanitary and housing reform depended upon the scientific theories of the time, which saw decaying organic matter as the source of disease. If some natural elements were to be feared, others were to be welcomed; the key to preventing 
epidemics was to allow the free flow of clean air, water, and sunlight. The free flow of capital, under laissez-faire, was also conceived of as a type of natural resource, and reformers trusted that it too would have a purifying effect on the urban housing market.

Octavia Hill is the subject of chapter two. She is a particularly interesting figure because she constantly evinced a love of nature for its spiritual benefits, yet had an intensely pragmatic and active personality. This chapter asks what Hill meant by the word "nature," and uses her writing and her efforts to bring nature within reach of urban slum-dwellers to answer the question. It would be difficult to underestimate the influence of John Ruskin on Hill's thinking and work, although their active friendship did not last beyond the 1870s. Hill added Ruskinian ideas about the spiritual and moral role of nature as the purest source of beauty and truth to the practical work of the earlier sanitary reformers. In her opposition to charity and "doles" in any form, she was a doctrinaire adherent of laissez-faire, yet she was willing actively to oppose the working of the free market in order to preserve open spaces in urban areas. The chapter will explore some of these tensions in Hill's work.

Chapter three brings us into the early twentieth century and the beginnings of the Garden City movement. Its focus is the Hampstead Garden Suburb, which united the older tradition of housing reform for London with the newer ideas of the Garden City. Henrietta Barnett, the driving force behind the project, had been a protégée of Octavia Hill and a long-time resident of Whitechapel, a parish of slums, where her husband was 
the vicar. She worked with Raymond Unwin, one of the most important architects in both the Garden City and the Arts and Crafts movements. If the model dwellings companies had co-opted nature to cure physical ills, and Octavia Hill had invoked nature's benefits for the individual soul, the founders of the Hampstead Garden Suburb hoped to marshal its forces to transform society and the relationships between classes. To them, the alienation of rich from poor was artificial and could be solved by a renewed intimacy with nature, in the form of gardens and green spaces, in everyday life.

Neither Godwin, Hill, nor Barnett were in revolt against Victorian society, and all were generally respected and received accolades for their work. Yet neither can it be said that any of them encapsulated the whole of British public opinion of the time. They presented their ideas of nature as though they were uncontroversial, although they each used nature in a way that threatened the interests of some groups or individuals. Yet by claiming that their methods and ideas were natural, they gave their arguments more authority.

Overall, by submitting historical ideas of nature to investigation, this thesis will shed light on their complexity and on the profound and tangled connections between a culture's concepts of nature and the political, economic and social realities that shape them. 
Chapter 1

"Shall we then counteract so wise a dispensation?"

Nature, political economy and efforts to purify slum dwellings

in the 1850 os and 1860 s 
Ever since Aesop's country mouse eschewed the luxury of his urban cousin's home in the polis, fleeing the mastiffs that guarded it and preferring his "beans and bacon in peace" to "cakes and ale in fear," narratives opposing the country and the city have contributed to perceptions and explanations of Western society. ${ }^{27}$ Poets, novelists and playwrights have portrayed rural characters as gullible, uncouth and stupid, or as the voices of common sense, loyalty and virtue. City-dwellers, in contrast, have been cast as unscrupulous, money-grubbing charlatans or as powerful, erudite, independent and clever. British cities began to grow more rapidly in the late eighteenth and early nineteenth centuries in response to industrialisation and rapid population growth. Victorians, seeking solutions to new urban problems, took pre-existing narratives pitting city against country life and manners and developed them into an understanding of urban and rural spaces as polar opposites. Debates about urban housing played a role in this understanding.

This chapter will examine writing about the "housing question" from the 1850 os and 1860s, showing which aspects and attributes of nature were proposed as remedies to the problems of urban slums. It will investigate popular writing about political economy to explore how classical economics influenced conceptions of nature and of cities. It will show how political economy itself was presented as a natural law, and how the failure of urban housing markets to allocate resources for the benefit of all citizens contributed to the city/nature binary.

\footnotetext{
${ }^{27}$ Joseph Jacobs, The Fables of Aesop (London and New York: Macmillan and Company, 1894), 15-17. Available online at www.pitt-edu/ dash/typeo112.html.
} 
Victorian housing reformers took an interest in the design of cottages for agricultural labourers. As late as the 1880 os many rural Britons still lived in wattle-and-daub cottages, many with earthen floors, and a hole in the ground for a toilet. Some still shared their homes with their cattle. ${ }^{28}$ There was an evident need for sanitary improvement, and there were reformers who shared with George Eliot's Dorothea Brooke an interest in designs for model cottages. ${ }^{29}$ However, rural hovels were by no means a novel phenomenon, and the tidal wave of mid-century debate broke primarily on the urban slums.

The 1840 and 1850 os produced a flourish of discourse about cities and in particular, about working-class housing. During the "hungry forties" cholera had returned to British cities. In addition, high food prices had hurt the working classes, especially before the repeal of the protectionist Corn Laws in 1846. Structural changes in the economy due to industrialisation were making certain skilled trades obsolete, causing distress which fuelled the Chartist movement. Led by artisans, this movement had begun in 1838 and called for the extension of the franchise to working-class men; its initial aims were moderate, but some branches of Chartism advocated strikes, riots and force to attain better conditions for working people. In Ireland, famine struck in 1845 and continued for several years. On the continent, 1848 saw the outbreak of revolutions and the

\footnotetext{
${ }^{28}$ Enid Gauldie, Cruel Habitations: A History of Working-Class Housing 1780-1918 (London: George Allen and Unwin, 1974), 51-56.

${ }^{29}$ George Eliot, Middlemarch (Harmondsworth: Penguin Books, 1965), first published 1871-2.
} 
overthrow of monarchs. It was feared that Chartist demonstrations could likewise spill over into violence. ${ }^{30}$

These fears influenced middle-class views of working-class homes. Earnest writers were motivated, perhaps, by "pure high-soul'd unselfishness" ${ }^{31}$ but also because the slums incubated crime and disease which affected indigent and affluent alike. The narratives they published provided a framework to understand and problematise the slums, an essential step towards practical solutions: before a problem can be solved, it must be defined. By describing the slums and their inhabitants writers presented a set of symptoms and prioritised those most susceptible to treatment. They hypothesised about root causes and possible remedies. They applied the scientific understanding of the day to problems of health, disease and sanitation, and portrayed the social and economic dimensions of working-class life in terms of their own political, economic or moral norms and assumptions. The elaboration of the question also established the framework of the debate, determining a set of possible answers and excluding others. Ideas about nature were a key theme in these narratives.

Writers described the slums of Britain's growing cities as places unfit for human habitation, with buildings that were filthy, overcrowded and poorly-maintained. Furthermore, their inhabitants, suffering from fever and distress, were a source of

\footnotetext{
$3^{30}$ Rather ironically, Louis-Napoléon Bonaparte, who would later benefit from the 1848 overthrow of the July Monarchy by establishing the Second Empire, served as a special constable at the 1848 Chartist demonstration. The meeting was, however, peaceful. Fenton Bresler, Napoléon III: A Life (New York: Carroll and Graf, 1999), 217-8.

${ }^{31}$ George Godwin, Town Swamps and Social Bridges (London: Routledge, Warnes, \& Routledge, 1859), vi
} 
infection, of crime and of vice to the whole city, and drained the community's resources by demanding charity. Motivated by fear of social disorder and by compassion for the suffering of fellow-humans, and believing that charity alone could not provide a permanent solution to the problem, some middle- and upper-class Victorians set up model dwellings companies. They commissioned plans and built examples of housing blocks to prove to other, less philanthropically-motivated investors that sanitary and moral concerns did not have to be sacrificed in order for a profit to be made. They believed that the supply of acceptable housing would eventually catch up to the massive demand created by rural-urban migration, and that as it did, rents would automatically return to a sustainable level.

The concrete efforts of model dwellings companies during these years were negligible in addressing the scale of the problem; they were, however, an essential element in creating narratives about working-class housing. Their stated purpose was to provide examples of well-built, sanitary housing that provided a respectable profit for investors while keeping rents affordable. The buildings they created were a physical expression of the discourse on the "housing question," and in turn they modified it, and provoked new ideas and solutions.

The architect and editor George Godwin (1813-1888) took a leading role in creating this public discourse about the inadequacies of working-class housing in London and in recommending remedies. The son of an architect, Godwin was solidly middle-class: he had begun his vocational training at thirteen, rather than being sent away to school like 
the sons of the aristocracy, yet he became wealthy enough to gather a substantial art collection, and to live all his life in the comfortable district of Kensington, in London. As editor of The Builder, "the most important and successful professional paper of its kind," ${ }^{2}$ from 1844 to 1883 , Godwin publicised various social causes. He wrote a series of extended pamphlets, based on his personal observations of poor districts of London, in an effort to raise public awareness of the poor living conditions and the disastrous consequences that threatened to ensue. London Shadows: A Glance at the "Homes" of the Thousands was published in 1854, followed by Town Swamps and Social Bridges in 1859 and Another Blow for Life in 1864. ${ }^{33}$ These publications collect together editorials he had previously published in The Builder, with updates and some additional material. Their primary purpose is to expose the conditions of the slums in order to provoke action; their priority is disease and sanitation, but crime and immorality are also matters for concern. In fact, like other writers of this period, Godwin linked sanitation with morality, believing that healthy homes would produce both sound bodies and virtuous lives. 34

Godwin was not the first to write about "the "Homes" of the Thousands". Public debate on sanitary conditions in the 1840 s had inevitably touched on housing. The novelist

\footnotetext{
$3^{2}$ G. B. Smith, "Godwin, George (1813-1888)", rev. Ruth Richardson and Robert Thorne. Oxford Dictionary of National Biography, (Oxford University Press, 2004). [http://www.oxforddnb.com/view/ article/10891, accessed 19 Nov 2012]

33 George Godwin, London Shadows: A Glance at the "Homes" of the Thousands (London: George Routledge and Co., 1854); Town Swamps and Social Bridges (London: Routledge, Warnes, \& Routledge, 1859); Another Blow for Life (London: Wm. H. Allen \& Co., 1864).

34 Susannah Morris quotes an 1854 report by Dr Southwood Smith (Octavia Hill's grandfather and a close colleague of Edwin Chadwick) linking the efforts of model dwellings companies both with decreased mortality and with increased morality: "Philanthropy in the Voluntary Housing Field in London," in Philanthropy, Patronage and Civil Society: Experiences from Germany, Great Britain, and North America, ed. Thomas Adam (Bloomington: Indiana University Press, 2004), 144.
} 
Charles Dickens, the journalist Henry Mayhew, and others had portrayed the lives, attitudes and neighbourhoods of London's poor in ways that garnered public attention, and the 185 os saw an outpouring of works on the same theme, Godwin's amongst them. ${ }^{35}$ As an architect, Godwin focussed on unsound buildings and the effects of these degraded environments on their inhabitants: "As the home, so the people," was his motto. ${ }^{36}$ This environmental determinism - the privileging of nurture over nature in the formation of human character - was an important Enlightenment concept. It was based upon the Lockean idea of the tabula rasa: that humans were created as blank slates, to be inscribed upon by their physical and social surroundings. If Godwin's tone occasionally shared some of the prevalent sensationalism, his aim was to do more than shock: "What is hereafter set forth has not been written to make a case," he claimed, "but to state plain facts." ${ }^{37}$ One major goal of his pamphlets was to garner support for the model dwelling companies, and he frequently made reference to them as havens of health in the midst of the slums; he also kept readers of The Builder up to date with their activities, amongst reports about such initiatives as the drinking fountains movement, and education for working men.

Model dwellings of the $1840 \mathrm{O}, 185 \mathrm{Os}$ and 1860 s tended to be built four to five storeys high, with plain and uniform exteriors and little to no ornamentation. They were often separated by paved courtyards which presented a neat and sanitary contrast with the

35 Gertrude Himmelfarb, The Idea of Poverty : England in the Early Industrial Age (New York: Alfred A. Knopf, 1984), 355.

${ }^{36}$ Godwin, Another Blow, 89.

37 Godwin, London Shadows, vii. This is somewhat disingenuous; Godwin adopts a conscious (though rather inconsistently sustained) tone of detached, scientific observation, but his explicit goal is to provoke action. 
earthen courts or broken paving of the slums they replaced. Certain companies provided playgrounds to keep children off the streets and away from danger. In some of these monuments to good sanitation, even wallpaper was prohibited for fear of vermin. ${ }^{38}$ The buildings had a stark, even inorganic appearance, yet it would be erroneous to conclude that their creators were uninterested in nature. The model dwellings relied heavily on specific understandings of nature that harmonised with the writings of political economists, as this chapter will make clear.

The four decades following the repeal of the Corn Laws in 1846 were the "high tide of laissez-faire" 39 when it was widely believed that the market could and would improve the conditions of all classes if allowed to operate without interference. The political doctrine of laissez-faire was based upon classical political economy, as described by writers such as Adam Smith and David Ricardo. Smith's landmark book An Inquiry into the Nature and Causes of the Wealth of Nations, often viewed as the founding text of classical political economy, was first published in 1776. Popularisers such as Jane Marcet in the 1820 s and Harriet Martineau in the 1830 s also used fictional stories and conversations to promote a widespread understanding of the ideas of Smith and his successors. $4^{0}$ T. R. Malthus' Essay on the Principle of Population, first published in

\footnotetext{
${ }^{38}$ Tarn, Five Per Cent Philanthropy, 46.

39 S. Gordon, "The London Economist and the High Tide of Laissez-Faire," Journal of Political Economy, 63 (6), (1955), 461-488. D. P. O'Brien places the heyday of classical economy earlier, 1800-1850, but public opinion and policy lagged behind the theorists. The Classical Economists Revisited (Princeton and Oxford: Princeton University Press, 2004), 1.

40 Jane Marcet, Conversations on Political Economy; in which the elements of that science are familiarly explained, 6th edition revised and enlarged (London: Longman, Rees, Orme, Brown, and Green, 1827).; Harriet Martineau, Illustrations of Political Economy: Selected Tales, edited by Deborah Anna Logan (Peterborough, Ontario: Broadview Editions, 2004).
} 
1798, was controversial but highly influential on debates about charity and poor-relief in the nineteenth century. Ricardo's work, less widely-read, inspired the writings of later political economists. James Mill was perhaps the only true Ricardian; but his son, John Stuart Mill, built his theories of political economy from a Ricardian foundation, while differing significantly in several areas. ${ }^{41}$ On the continent, the most prominent classical economist was probably Jean-Baptiste Say, whose Traité d'Économie Politique was first published in 1803; but the eighteenth-century Physiocrats, such as François Quesnay and Anne-Robert-Jacques Turgot, had influenced Smith's work.

The younger Mill's Principles of Political Economy was first published in $1848.4^{2}$ It sold so quickly that a second edition appeared the following year, and the book went through seven editions before the author's death in 1873. It became a textbook for universities and was "a major intellectual authority for the whole of the last half of the nineteenth century." 43 According to economic historian Maxine Berg, Mill's Principles "summed up the state of political economy over the generation between the 1820 s and the late 1840s." ${ }^{44}$ This was the same classical political economy that underpinned laissez-faire policies. Mill was also, however, influenced by Auguste Comte's positivism and offered a few, moderate socialist ideas. The success and influence of Mill's Principles make it a

\footnotetext{
41 "He tried to incorporate Ricardo's work into his own, though in doing so he emasculated the former more or less completely." See O’Brien, Classical Economists , 52.

$4^{2}$ John Stuart Mill, Principles of Political Economy, with Some of their Applications to Social Philosophy. Edited by W. J. Ashley (London: Longmans, Green, and Co., 1909). First edition 1848.

43 Maxine Berg, The Machinery Question and the Making of Political Economy, 1815-1848 (Cambridge: Cambridge University Press, 1980), 316.

44 Ibid., 317. Berg argues that at the time of its first publication Mill's Principles was “idiosyncratic," but that it soon became hugely influential.
} 
good source for investigating ideas about the creation and distribution of wealth in the 1850 and 1860 s.

For Mill, nature is an important factor in political economy. Access to natural resources such as fertile land, pleasant climate, or coal and metal ores explains in part the relative wealth and poverty of nations. Mill finds, however, that when the natural resources are too easily obtained, they lead people to prioritise leisure over the attainment of wealth. 45 Mill views nature as "external" to humans. ${ }^{6}$ This, as Raymond Williams has observed, was an innovation of the eighteenth century. ${ }^{47}$ Previously, humankind had been seen as part of God's creation; having a privileged role within it, certainly, but not separate from it. The agrarian reformers, Enlightenment scientists and inventors of the 1700 s viewed nature as definitely external to humankind and, consequently, available to meet human needs. Mill lauds humanity's achievement in using the knowledge of nature to bring its powers under human control, for the benefit of all. "The legitimate employment of the human faculties," he states, is "that of compelling the powers of nature to be more and more subservient to physical and moral good." 48

Like Mill, George Godwin viewed nature as a set of resources available to humans to control and use for their benefit. In common with sanitary reformers of the time, his writing highlights three specific resources - pure air, clean water and sunlight - and he

\footnotetext{
45 Mill, Principles, 102-107.

${ }^{46}$ Ibid., 39 .

47 Raymond Williams, "Ideas of Nature," in Problems in Materialism and Culture (London: Verso, 1980), 75-77, 79 .

48 Mill, Principles, 979.
} 
argues that houses well-supplied with these will enhance their inhabitants' physical and moral well-being. Homes are degraded, dangerous and even "unnatural" when they are cut off from the flow of these three resources. Godwin takes a scientific tone, describing, for example, Dr John Snow's work tracing the source of a cholera outbreak to a contaminated water source, or calculating the time it would take for the air in an overcrowded bedroom to become so vitiated with exhaled carbonic acid (CO2) as to poison its occupants. ${ }^{49} \mathrm{He}$ describes the "unnatural gloom" of basement dwellings, ${ }^{50}$ and the misery of those who "are born and die in these underground dens, into which a ray of sunlight can scarcely struggle," lacking "light, that necessary of life." ${ }^{1}$

In order to reap the benefit of freely-available air, water and light, houses needed to be designed and placed so that they captured the flow of these resources. Mill had described the relationship between human labour and natural resources thus:

If we examine any other case of what is called the action of man upon nature, we shall find in like manner that the powers of nature, or in other words the properties of matter, do all the work, when once objects are put into the right position [...] $\mathrm{He}$ has no other means of acting on matter than by moving it. Motion, and resistance to motion, are the only things which his muscles are constructed for [...] but this is enough to have given all the command which mankind have acquired over natural forces immeasurably more powerful than themselves; a command which, great as it is already, is without doubt destined to become indefinitely greater. [...] Labour, then, in the physical world, is always and solely employed in putting objects in motion; the properties of matter, the laws of nature, do the rest. ${ }^{2}$

\footnotetext{
49 Godwin, Town Swamps, 50-51; 36. He even includes a number of diagrams to show the number of cubic feet of air necessary to supply oxygen.

$5^{0}$ Ibid., 13 .

${ }^{51}$ Ibid., 18.

${ }^{2}$ Mill, Principles, 24-25.
} 
The model dwellings companies similarly strove to put houses "into the right position" to benefit from the powers of nature, being purified by the free flow of air, light and water.

But these were not the only aspects of nature that the model housing proponents wanted to apply to the slums. They aimed to work on a sound commercial basis, placing their companies within a free market system to profit from the free flows of capital, labour and goods, bringing financial and moral benefits to the working-class people they housed. Most model dwellings companies operated on a commercial basis, aiming to pay a dividend of around five per cent to their investors. ${ }^{53}$ If their buildings were "model" in that they were intended as examples of the kind of building that ought to be provided, their commercial soundness was also intended to motivate widespread imitation.

Early classical economists developed their system of laissez-faire political economy during the Enlightenment. At a time when natural scientists were endeavouring to discover the rules that governed the natural world, political economists, by observing human behaviour, devised a system of laws that they believed governed economic interactions. These laws were represented as operating beyond the conscious control of individuals - as real laws of nature. Adam Smith famously described the price mechanism as being like an invisible hand that allocates resources, capital and labour efficiently and enriches all who participate in the market; it has been suggested that he

53 One of the companies, the Peabody Trust, was established as a charitable trust rather than a commercial operation; but even this, since it was intended to be self-perpetuating, aimed to make a five percent return on its properties to enable new building projects. Tarn, Five Per Cent Philanthropy, 46. 
saw the human propensity to exchange as a universal phenomenon, analogous to the force of gravity. ${ }^{44} \mathrm{He}$ was influenced by natural law philosophy: the belief that the material world is based on laws, discoverable by observation, which, when understood and followed, ensure the maximum benefit and progress of humankind. 55 Natural law philosophy had grown out of the teachings of the mediaeval Scholastics and taken a rationalist turn during the Enlightenment. Its laws reflect a conception of the natural world as ordered, rational and essentially benevolent. It is significant that not only "external" nature, but the workings of human society - including the creation and pursuit of wealth - were understood to follow their own, "natural" laws. Any attempt to solve economic problems had, therefore, to abide by these laws in order to be effective.

In popular literature about political economy, market forces are described as "natural." Ella, the heroine of Harriet Martineau's Weal and Woe in Garveloch, explains Malthusian principles to her friend as "the natural course of things." In this 1834 story, a Scottish fishing village enjoys a booming economy for a few years, encouraging a population explosion; when a poor harvest and a decline in the fishery bring hard times, disease and famine decimate the village. Ella explains that the only way to prevent such distress is for "the body of the people [to] understand those natural laws by which and under which they subsist." ${ }^{6}$ Malthus' theory, according to which an increase in the food supply leads to an increase in population until it reaches the maximum level that the

\footnotetext{
54 Noriss S. Hetherington, "Isaac Newton's Influence on Adam Smith's Natural Laws in Economics," Journal of the History of Ideas 44:3 (July 1983), 497-505.

55 O'Brien, Classical Economists, 27.

${ }^{56}$ Harriet Martineau, "Weal and Woe in Garveloch," in Illustrations of Political Economy (3rd edition), in 9 volumes (London: Charles Fox, 1832), volume 2. Available at http://oll.libertyfund.org/title/ 1690/143123. Accessed July 4th, 2013. Chapter 7.
} 
food supply can support, views "checks" such as famine and disease as modes which nature takes to "repress" a "redundant population." ${ }^{77}$ Similarly, in Garveloch, the protagonists learn to understand the "natural laws" and Ella's brother refrains from marrying the young widow he loves, for fear of further increasing the population.

In Martineau's tale, the laws of political economy are Janus-faced. Implacable and inexorable, they can be flouted only temporarily before they bring down starvation, disease and death; but for those who understand them and modify their behaviour accordingly, they produce wealth and virtue. This understanding of economic principles relies upon a similarly ambiguous view of nature as threatening, yet potentially susceptible to rational human management.

Another popular work of the time, this one aimed at schoolchildren and authored by Jane Marcet, explained the basic law of political economy thus:

Both the virtues and vices of mankind tend to destroy equality; the laborious, the intelligent, and skilful, will raise plentiful harvest; Nature thus rewards their exertions. The possessions of the idle, the careless, and the ignorant, will, on the contrary, gradually degenerate. Nature has annexed this penalty to their neglect. Shall we then counteract so wise a dispensation of Providence, by giving to the idle the reward of industry, and making the industrious bear a punishment due to the idle?5

Political economy, then, was viewed not as a characteristic of a particular society at a particular moment, but as a universally applicable system of laws. It was a "dispensation

\footnotetext{
57 Thomas Robert Malthus, An Essay on the Principle of Population (London: J. Johnson, 1798), IV:6. Available at http://www.econlib.org/library/Malthus/malPop2.html\#Chapter\%20IV. Accessed July 4, 2013.

${ }^{58}$ Marcet, Conversations, 40
} 
of Providence" and as such, should not be counteracted. It was heretical even to imagine an alternative system: "It is dangerous to trust to your judgment when it leads you to conclusions so different from the established course of nature," the narrator chides her fictional interlocutor. 59

Mill differed from previous political economists in viewing the distribution of wealth as socially determined. He wrote in his Autobiography of

that general tone by which [the Principles] is distinguished from all previous expositions of Political Economy [and which] consisted chiefly in making the proper distinction between the laws of the Production of Wealth, which are real laws of nature, dependent on the properties of objects, and the modes of its Distribution, which, subject to certain conditions, depend on human will. The common run of political economists confuse these together, under the designation of economic laws... $\frac{60}{6}$

Mill here reveals the extent to which the whole system of classical political economy had been seen as a natural phenomenon, even as he himself begins to break the system into natural and social components. "Not long ago, respectable economists were still boldly calling these 'laws' of their science "natural laws'," wrote O. H. Taylor in $1929 ;{ }^{11}$ by then, economists had rejected entirely the idea that economic principles were laws of nature.

59 Ibid., 41.

6o John Stuart Mill, Autobiography (Indianapolis: Bobbs-Merrill, 1957, first published 1873), 159-160, emphasis mine.

${ }^{61}$ O. H. Taylor, "Economics and the Idea of Natural Laws," The Quarterly Journal of Economics, 44:1 (November 1929), 1-39. 
Still, the idea that a free-market system was natural had proved very persistent. Beatrice Webb recorded in her diary as late as 1890 a conversation with her cousin Mary and the latter's husband, the businessman and statistician Charles Booth.

'I have found a new definition of socialism,' said Charlie [...] 'The prevention by a paternal state of the consequences of a man's action: [...] the substitution by a paternal government of artificial consequences for the natural consequences of a man's action: defining 'natural consequences' as the reward a man would get under a strict competitive system.' 62

Booth evidently viewed "strict competition," the bedrock of laissez-faire, as a more natural system than paternalism.

The publication of Charles Darwin's Origin of Species in 1859 had further blurred the lines between free-market liberalism and natural processes. Darwin wrote of the "Struggle for Existence," and this inspired some of his followers to enshrine competition, or the survival of the fittest, as the motive force of evolution. Social Darwinists believed that those who had a competitive edge in acquiring the necessities of life could win more opportunities to survive and reproduce. Nature, then, was, like the free market of the classical economists, self-regulating, and able to allocate resources efficiently to those species that could use them best. Yet at the same time, it could be menacing. Mike Hawkins has written of the "janiform quality" of nature in a social Darwinist world view:

\footnotetext{
${ }^{62}$ Beatrice Webb, The Diary of Beatrice Webb, Vol. 1: 1873-1892, ed. Norman and Jeanne MacKenzie (Cambridge, Mass.: Belknap Press, 1982), 325-6. Beatrice Webb (still Beatrice Potter at the time of this conversation) would become a prominent socialist writer and member of the Fabian society; Charles Booth is best known for his multi-volume survey of London life, with its classifications and descriptions of people at various levels of income and social status.
} 
it was both model and threat. ${ }^{63}$ As we have seen, the idea that classical economics was not a theory constructed by humans so much as a discovery of eternal, natural laws existed well before Darwin. Indeed, scholars have noted the influence of Malthus on the great naturalist. However, the importance which Darwin accorded to the "Struggle for Existence" surely bolstered classical political economy at a time when many voices were proposing alternatives. Indeed, radicals, republicans and socialists had already deployed the ideas of Darwin's predecessor, the French naturalist Jean-Baptiste Lamarck, whose theory of evolution did not depend on competition. Lamarck believed that individuals could pass on to their progeny characteristics they had acquired; for example, the ancestors of giraffes might have lengthened their necks from repeatedly stretching to reach leaves, and the offspring of those individuals which did this most would be born with the more developed necks. Under Lamarckism even a weak individual could, by the actions it chose to perform, improve its own and its descendants' adaptation to the environment. To radicals and socialists, these ideas gave nature's stamp of approval to bettering the conditions of the working classes, since progress and improvement were nature's chief characteristics. Indeed, Darwin may have delayed publication of the Origin precisely in order to avoid his own ideas being "pirated" by radicals. ${ }^{64}$ In the less restive 1850s, a Darwinian world view "could be enrolled in the same ideological cause as the original Malthusian doctrine, i.e. to support free markets and oppose doctrines of equality." ${ }_{5}$

\footnotetext{
${ }^{63}$ Mike Hawkins, Social Darwinism in European and American Thought, 1860-1945 (Cambridge: Cambridge University Press, 1997), 18.

${ }^{64}$ Ibid., 43.

${ }^{6}$ Ibid., 51.
} 
In an age when the principles of laissez-faire economics appeared to be as natural as the laws of gravity, established by a benevolent Providence for the good of humankind, the appearance of slums was troubling. Nobody had set out to produce the urban residential environments that had sprung up in response to industrialisation. Slums formed when in-migrants crowded into buildings (often in back alleys) originally designed for much lower densities of habitation, or when speculative builders put up working-class housing - often poorly built and densely-packed, seldom provided with appropriate sanitary arrangements - on scraps and parcels of land close to industrial sites. Slums and their inhabitants appeared without anyone's consent or invitation, and their very existence was a challenge to laissez-faire orthodoxy. According to classical political economy, individuals pursuing an increase in their personal wealth, interacting through the mechanism of the market, would provoke a rise in the whole community's standard of living; Adam Smith’s “invisible hand” was not supposed to craft unhealthy, unpleasant spaces for urban workers that seemed to be even worse than the rural homes they had fled. David Harvey has argued that cities are spaces in which the many positive and negative economic externalities which urban activities produce make it impossible for market forces to allocate resources efficiently. ${ }^{66}$ During the second half of the nineteenth century, as efforts to fix the slums by reintegrating them into a rational, free-market system repeatedly foundered, the failure of these spaces to conform to "natural" market forces made them appear unnatural.

\footnotetext{
${ }^{66}$ David Harvey, Social Justice and the City (Athens and London: University of Georgia Press, 2009. Revised edition; first published 1973), 57-60.
} 
Godwin shared the prevalent view that housing for the working classes should be provided by private means and on a commercial basis. He believed that if honest men could build houses that conformed to sound architectural and sanitary standards and rent them out at a modest profit, then other investors would follow their example. At the same time, the working-class renters would surely choose the healthier, more attractive dwellings if the cost were not too high. Godwin's adherence to the laissez-faire consensus had helped to make The Builder a success after a shaky start: the journal's first two editors had been Owenite socialists and under their direction circulation had been dismal. ${ }^{67}$ While Godwin shared with socialists a deep concern for the poor and a strong desire to help them improve their circumstances, his experience had certainly shown him that working within the prevailing laissez-faire orthodoxy was more likely to produce results than challenging the status quo.

Godwin proclaimed that "when God gives a blessing to be enjoyed, he gives it with a duty to be done; ${ }^{68}$ he believed duty was one motivation for trying to relieve the distress of the poor who lived in such deplorable conditions. But he thought that the commercial spirit was an even more powerful inducement. Invoking the fear that disease could spread (as it had in the cholera epidemics of 1832 and 1848) to all sectors of the city, as well as the financial cost of criminal justice, he argued that investment in better housing was common sense and would not contravene laissez-faire principles:

\footnotetext{
${ }^{67}$ Robert Thorne, "Building Bridges: George Godwin and Architectural Journalism” in Victorian Values: Personalities and Perspectives in Nineteenth-Century Society, edited by Gordon Marsden (London: Longman, 1990)

${ }^{68}$ Godwin, Town Swamps, 20.
} 
It must not be supposed that we seek, by these papers on the dwellings of the London poor, to awaken sympathy in behalf of individuals, to be expressed by pecuniary assistance to them. Our object, it must be evident to all who will give it any consideration, is permanent improvement and general amelioration. We would show the great want there is of decent accommodation for the poorer classes, the miserable state in which thousands are lodged, the degrading and demoralizing effect of this upon the character; and then point to the fact that decent accommodation may be provided for them, and a fair return be obtained for the money laid out in effecting it, to say nothing of the sums that would be saved to the community by the diminution of crime, disease, and death (not confined, let it be remembered, to the locality of the originating hovels), to which such improvements would unquestionably lead. ${ }^{69}$

The "fair return" that Godwin referred to was commonly agreed upon at five percent, although some charitable investments paid a little more or less than this. In some cases, such as Octavia Hill's housing projects, any profit over five percent was to be reinvested in improvements to the apartments themselves rather than paid in dividends. Housing activists believed that, by insisting upon keeping the investment profitable, they would achieve a number of benefits. First, other investors would be persuaded that they could make an honest profit, and this incentive would ensure that supply of appropriate housing would match demand. Second, renters could retain the dignity of entering into a valid contract rather than be degradingly dependent on hand-outs; this would help them retain a respectable and productive work ethic rather than encouraging idleness. Finally, the companies would avoid distorting the housing market with charitable donations, and encouraging more migrants to come to cities than the job opportunities warranted.

Such arguments undoubtedly show a certain sensitivity towards the working classes and their self-respect. Reformers such as Godwin express genuine compassion for those who

${ }^{69}$ Godwin, London Shadows, 13. 
were forced to live in homes that endangered their health and thus their livelihoods. In addition, they regarded the poor not as superfluous but as an integral part of the national economy. They believed that the interests of rich and poor were compatible. Godwin frequently describes the health of a working man as his "capital," thus placing any who built and maintained housing or workshops that destroyed health in the category of common thieves. ${ }^{70}$ If all classes worked to improve their own conditions, the national wealth would increase and all would benefit.

Yet at the same time Godwin refused to acknowledge that the market was not, on its own, providing for the poor. "Ten times the capital invested could not have solved the housing problems of London. Even the Victorians could not, or would not, contribute sufficient capital to take care of all the ills of the urban society they had created." Much more money could be made from slum landlordism. ${ }^{71}$ Wages were simply too low for most urban workers to afford housing that met either their own standards or those the middle and upper classes thought they should have. The truth was that even those societies that paid their five per cent dividends - and this in itself, since it was considerably lower than other available investment opportunities, may be considered a market-distorting subsidy - never did so under perfect market conditions. The land they bought was obtained at below market value, since the law required that it be used for working-class housing to replace demolished slums, rather than any more lucrative activities. In addition the government often provided low-interest loans for the housing

\footnotetext{
$7^{70}$ Godwin, Another Blow, 68.

${ }^{71}$ Wohl, Eternal Slum, 173,188.
} 
societies. ${ }^{72}$ These subsidies were hidden and the societies presented as examples of philanthropic capitalism. "Good may be done and money made at the same time," insisted Godwin. ${ }^{73}$ In this way, the free market could be presented as more efficient than it actually was, more radical critiques could be diverted, and the ignorant or unscrupulous builder or landlord presented as the villain of the piece.

Some writers reserved their spleen for the "large class of middle-men" who leased and then sublet dwellings. London clergyman Thomas Beames wrote in 1850 that profits made by middlemen kept rents high, and worse, cut off the poor from "the charities which would accrue to them were there no intermediate agents between them and the landlord." 74 Beames assumed that landlords themselves would take a friendly interest in their tenants if they knew them personally. The idea that the gentry and the labouring poor were natural allies against traders and dealers was an important component of a paternalistic model of society in the eighteenth century, as E. P. Thompson has described. He critiques the notion that "the poor" can be lumped together as an indiscriminate group, since this "carries the suggestion that the bulk of the working population were deserving of gentry condescension, and perhaps of charity (and were somehow supported by the gentry instead of the direct opposite)."75 Later in the

\footnotetext{
${ }^{72}$ Wohl, Eternal Slum, 145, 173, 197; Gertrude Himmelfarb, Poverty and Compassion: The Moral Imagination of the Late Victorians (New York: Vintage Books, 1991), 209.

73 Godwin, Town Swamps, 20.

74 Thomas Beames, The Rookeries of London: Past, Present, and Prospective. 2nd edition. (London: Thomas Bosworth, 1852. First published 1850), 301.

75 E. P. Thompson, Customs in Common (Pontypool: The Merlin Press, 1991), 17, 208-209.
} 
nineteenth century the idea that people of different classes should have personal contact would influence the work of both Octavia Hill and the Barnetts, as we shall see.

Godwin's writings refer periodically to model lodging-houses built by the Society for Improving the Conditions of the Labouring Classes and the Metropolitan Association for Improving the Dwellings of the Industrious Classes. ${ }^{76} \mathrm{He}$ warmly approves their sanitary arrangements, and cites statistics to show their effectiveness in reducing mortality during epidemics. London Shadows reports a gratifying five per cent return on investments for the various companies. 77 By 1859 it was evident that the model dwellings associations were not as financially successful as had been hoped: rising land prices had made it more difficult to pay for buildings, amenities and dividends while maintaining a rent that labourers could afford. In many blocks, apartments remained unlet. Yet Godwin's faith in commercial philanthropy and the wholesome effect of free market principles is unshaken; rather, he explains the disappointing results as due to "prejudice" on the part of the working classes against sanitary measures and the kinds of buildings being produced. ${ }^{78}$ Godwin notes that these prejudices (which he does not identify in detail) mean that "persons who own the inferior description of house property can point with a sort of triumph to the appreciation by their tenants, and the

\footnotetext{
${ }^{76}$ See Tarn, Five Per Cent Philanthropy, and Morris, "Philanthropy in the Voluntary Housing Field," for details of these and other model dwellings companies.

77 Godwin, London Shadows, 72.

${ }^{78} \mathrm{He}$ had earlier noted that some respectable young weavers preferred to live in families rather than in the single-sex model lodging-house provided by the MAIDIC in Spitalfields; this "prejudice" in favour of family life and feminine influences Godwin, however, approved, and the model dwellings companies provided more family accommodation as it became obvious this would be more popular: Ibid., 34; Tarn, Five Per Cent Philanthropy, 24.
} 
profits of their dwellings, in comparison with some of the model buildings." ${ }^{79}$ Godwin points to education about sanitation as the way to eliminate these prejudices, but he also calls for buildings to be made more attractive to the class of people who can afford the rents, which are high in comparison with the slum houses. Indeed, these high rents, together with the disciplinary character of the management style, discouraged potential tenants. Sanitarians inveighed against practices that were, in fact, more than mere "prejudices" and therefore hard to eliminate. For example, the model dwellings forbade subletting in order to combat the evils of overcrowding. But the ability to take in a lodger could be a crucial strategy to supplement the family finances when regular income was reduced by sickness or lack of work.

Not only working-class lives, but working-class neighbourhoods were difficult for middle-class observers to understand. The dark labyrinths of courts and alleys were confusing to outsiders; Godwin, for example, was guided by a policeman on his expeditions. He aims to make the slums of London more legible to his readers. He adopts a privileged viewpoint, claiming that his knowledge of the slums, based on his education and understanding, is superior to the knowledge gained by long residence. For example, he frequently asks women whether they believe their homes to be healthy, and on receiving an affirmative, asks the women how many of their children have died. Since this is usually a significant number, Godwin undermines their authority to evaluate their own homes. Similarly, John Brown's illustrations in Godwin's books render visible and legible spaces normally hidden to the middle classes. In one drawing, a house is shown

\footnotetext{
${ }^{79}$ Godwin, Town Swamps, 8.
} 
with its wall removed, like a dolls' house, revealing all the rooms inside, with their many inhabitants. "We have, Asmodeus-like, removed the front wall from the top to the bottom, that our readers may examine without fear, and at their leisure, the extraordinary and distressing scene it presents." ${ }^{80}$ Thus readers are offered a viewpoint unavailable even to slum residents. This privileged view gives Godwin and his readers authority to call for and effect the reshaping of homes and neighbourhoods which are not their own.

Not only slums, but cities as a whole, might be places in which the processes of political economy became illegible. Martineau's Weal and Woe in Garveloch is set in a remote Scottish island community with only one industry and limited arable land, because in this simplified setting her Malthusian principles are easy to comprehend. In cities, however,

the mind of the observer is perplexed by the movements around him. The comings and goings, the births, deaths, and accidents, defy his calculations; ... In every city, however crowded with a half-starved population, there are many more who do their utmost to encourage population than can give a sound reason for their doing so; and while ... there is no lack of inaccurate explanations why our workhouses are overflowing, our hospitals thronged, and our funeral bells forever tolling, it is difficult to ascertain the real state of the case. ${ }^{81}$

Cities become unnatural spaces because in them, the natural laws of political economy are obscured to the point of illegibility, with disastrous consequences.

\footnotetext{
${ }^{80}$ Godwin, London Shadows, 17.

${ }^{81}$ Martineau, "Weal and Woe in Garveloch," chapter VII.
} 
As a professional architect, Godwin presented himself as a qualified evaluator of the homes of the poor. He aimed to improve building practices through elevating the status of the architectural profession, drawing attention to low standards, and stimulating interest in philanthropic capitalism, without challenging the tenets of liberalism. In between his other duties he made time to go into slum areas and describe the conditions he saw. These areas were entirely separate and hidden from the middle-class gaze. Godwin described himself as an intrepid explorer, making visible through his efforts and his qualified architectural eye the diseased parts of the urban body: "To investigate the houses of the very poor in this metropolis is a task of no small danger and difficulty: it is necessary to brave the risks of fever and other injuries to health, and the contact of men and women often as lawless as the Arab or the Kaffir." 82

This description of slums evokes Africa, with its deserts and jungles, a continent viewed as wild and savage. Ideas about natural laws, including those that supposedly governed economic behaviour, relied upon a conception of nature as inherently ordered, regular and benevolent. This was the nature that could be known and controlled by humans and made subservient to their good. However, nature could also be understood as wild, dangerous and disorderly. ${ }^{83}$ These competing ideas exist side by side, making the idea of nature ambiguous and dynamic. The Romantics of the early nineteenth century drew heavily on imagery of wild and dangerous spaces as places where humans may be overwhelmed by the sublime, experiencing a kind of terror that provides them a spiritual

\footnotetext{
82 Godwin, London Shadows, 1.

83 George Boas, "Nature," in Dictionary of the History of Ideas: Studies of Selected Pivotal Ideas, ed. Philip P. Wiener, I:346-351 (New York: Charles Scribner's Sons, 1973), 350.
} 
benefit. When humans attempt to control nature, they may provoke unintended and horrific consequences, as Mary Shelley's Frankenstein (1819) warns. But this concept of nature as fundamentally irregular has also been domesticated into an ideal of picturesque beauty, providing spiritual and physical refreshment, and contrasting with the uniformity and symmetry of machine-made objects and modern buildings. If Godwin ascribes heartily to a conception of nature as instrumental to good health, in the form of air, water and light, there is some ambiguity in his attitudes towards other, more irregular, forms of nature that embody this second viewpoint.

Because his professional training conditioned him to know about buildings, Godwin's narrative begins with the actual fabric of the houses, their disrepair, their situation and their amenities. He sees buildings before he sees people. When he moves on to describe the inhabitants of the buildings they seem to be as much a part of the decor as the rotting wallpaper or the meagre furniture. The buildings, by shaping and constraining family life and physical health, produce the working classes. Godwin cautions his readers not to judge the poor: not only their physical, but their moral state is determined, he asserts, by the spaces in which they live: "We have, during the night, under a sense of duty, penetrated some of the darkest recesses of Whitechapel and its neighbourhood, and have seen men and women under circumstances wherein virtue is impossible, and indulgence in vice or the commission of crime seems scarcely other than natural." ${ }^{84}$ Like market forces, the urban processes by which unhealthy spaces produce unhealthy people are presented as natural laws which it is useless to resist. Only by

\footnotetext{
${ }^{84}$ Godwin, London Shadows, 21.
} 
changing the environment can residents' lives be improved. Godwin uses a natural metaphor: "The child was small, drooping, and bleached, like many of the plants which attempt to vegetate in such places." 85

Godwin often portrays nature in the slums as being out of place. There is, inevitably, much discussion of organic material piling up and polluting the air, whether from overflowing cesspools, overcrowded cemeteries, piles of food waste, or refuse from slaughterhouses and dairies situated too close to residential areas. The predominant theory of disease transmission at the time was miasmatic. Miasmas, that is, gases or particles emanating from organic substances or living beings, were presumed to pollute the air, causing not only nuisance in the form of bad odours, but also diseases. Godwin is eloquent on the effects of vitiated air on the human organism: it produces sleepiness, depression, complaining, disease and death. ${ }^{86}$ It may even be blamed for that "monster evil," intemperance: "the impurity of the air creates a craving for stimulants." ${ }^{87} \mathrm{Near}$ Bow-common, sickly children suffering from their homes' proximity to an open sewer "resemble the poor plants observable in some of the windows about;" ${ }^{8}$ both children and plants attempt to grow where they should never have been planted. In London Shadows in particular, when Godwin describes non-human nature in the slums, it is out of place. The sky can be seen through holes in the roof of a room whose only greenery is

\footnotetext{
85Ibid., 6.

${ }^{86}$ Godwin, Town Swamps, 60, 64.

${ }^{87}$ Ibid., 26.

${ }^{88}$ Ibid., 56.
} 
the mildew on the walls; ${ }^{89}$ vegetables are stored under beds, ${ }^{90}$ and rabbits share living space with overcrowded families. ${ }^{91}$ Even cattle kept in urban dairies are unhappy and unhealthy, breathing polluted air and thus, no doubt, providing poor-quality milk. ${ }^{92} \mathrm{In}$ a cartoon illustration, an urban sheep is pictured as black next to its white-fleeced country cousin: "Thou beest wondrous grim, sure!" exclaims the "yokel” sheep in alarm; the Hyde-Park beast replies drolly, "To this complexion ewe must come at last," predicting by extension the fate of human migrants to London, as Godwin makes clear. ${ }^{33}$ Nature in the city is no longer truly natural; it is corrupted and degraded by human activity.

However, there are exceptions to Godwin's characterisation of nature as out of place in working-class districts. In London Shadows, he reports on a close-knit neighbourhood of silk-weavers suffering from drastically falling wages as they desperately battle against the competition of machine-made cloth. He provides updates on this community in the two later books. Godwin portrays these weavers in a very sympathetic light, particularly in the 1854 account. They are hard-working and value education; despite financial distress they maintain family bonds and remain respectable even while forced to live and work in overcrowded and unsanitary rooms. They are, he notes, descended from French Huguenots, Protestants driven out of their homeland by persecution, and some of them have distinctively French surnames. The report in London Shadows had

\footnotetext{
${ }^{89}$ Godwin, London Shadows, 5 .

${ }^{\circ 0}$ Ibid., 3.

${ }^{91}$ Godwin, Another Blow, 37.

${ }^{22}$ Godwin, Town Swamps, 12-14.

93 Godwin, London Shadows, 58.
} 
previously appeared in The Builder, and in the book Godwin adds letters received from a few of the silk-weavers who had evidently read the report and testified to its accuracy; this evidences not only the wide readership of the periodical, but the level of education and literacy these highly-skilled workers possessed. Godwin does, however, abridge a lengthy and sentimental poem sent in by one correspondent, noting that it unfairly blames employers for the weavers' distress. ${ }^{94}$ Hand-weavers and other domestic outworkers could, argues Maxine Berg, be treated with compassion and even given public aid, because they were seen as an anomaly, "relics of a dying civilisation," rather than a persistent threat to industrial progress or drain on public resources. 95 It may also be significant that this group of Spitalfields silk-weavers were Protestant; Linda Colley has described Protestantism as a crucial element in the formation of British identity. ${ }^{96}$ Godwin writes approvingly of their fondness for flowers: "few houses, even of the poorest, are destitute of a bit of 'greenery,'" and one of the "most respectable of the class" whom Godwin interviews lives "out of the web of streets in a cottage with a garden." 97

While these weavers receive praise for their interest in gardening - and even rearing pet pigeons and canaries - other groups' tenuous connections with nature are treated more

\footnotetext{
94 Ibid., 33-38. Ten years later, in Another Blow for Life, 5-7, Godwin chides the weavers for their persistent failure to understand the economic realities of their situation; despite their intelligence and respectability their demand for protective tariffs and tendency to blame their employers for their poverty were not politically correct in the age of laissez-faire.

95 Berg, Machinery Question, 312.

${ }^{96}$ Linda Colley, Britons: Forging the Nation 1707-1837 (New Haven and London: Yale University Press, 1992), 11-54. Colley also describes Francophobia as a unifying factor for the nations that made up the United Kingdom, but argues that this was based primarily on its Catholicism; for Godwin and his readers, the Protestant creed of the Spitalfields weavers would likely have outweighed their foreign ancestry.
}

${ }^{97}$ Godwin, London Shadows, 33. 
dismissively. In London Shadows, Godwin often notes that neighbourhoods whose conditions are particularly degraded are populated by "low Irish." In fact, he frequently places the Irish in lists of slum inhabitants along with Jews, dock labourers, foreigners, German musicians, and "persons of loose character;" 98 one "Rookery" is inhabited by "the poorest Irish lodging-house keepers, tramps, costermongers, thieves, and the lowest class of street-walkers [...] small shopkeepers, receivers of stolen goods, brokers, and publicans." 99 By these undifferentiated lists Godwin conflates national, occupational and criminal categories so that the boundary between being Irish (or otherwise foreign), being poor, and engaging in criminal or immoral behaviour appears to be porous.

Many of the Irish Londoners in Godwin's accounts are costermongers; ${ }^{100}$ he reports seeing unsold vegetables, flowers, fruit or fish stored under beds, another instance of nature out of place. ${ }^{101}$ In Agar-town, an "extensive and ill-built district" near Kings Cross Station, costermongers keep "useful" donkeys as well as dogs and pigeons, and "many desperate attempts are made to cultivate plants." ${ }^{102}$ Although many of the houses here are provided with large gardens, Godwin has nothing good to say about them, merely describing the dirt and mud of the road in front.

\footnotetext{
98 Ibid., 21, 23, 29.

99 Ibid., 2.

${ }^{100}$ Sellers of fruits and vegetables; often, they bought up spoiled or damaged produce to sell from barrows or baskets in working-class districts.

${ }^{101}$ Ibid., 3 .

${ }^{102}$ Ibid., 7-9.
} 
As Godwin was writing the articles that would become London Shadows, the Great Famine was still driving Irish immigrants to England and further afield. Many of the people he describes in the book had, very recently, been rural labourers, living in close proximity to unmediated nature. ${ }^{103}$ But this country life was far from ideal. Irish peasants lived in dire poverty, in rural dwellings hardly more sanitary than the London slums to which so many emigrated. They might live in single-room dwellings and share their homes with their animals. In 1848 , as Britain was experiencing compassion fatigue from several years of Irish famine, one newspaper described rural Irish life in these unsympathetic terms: "To squat down under a stone or mud cabin in the corner of a waste moor, with fuel from the bog, potatoes, and a few cattle, pigs and poultry sharing the cabin - half house, half stable, the filth within and around which is preserved like gold - that is the ordinary picture of Irish contentment." 104 The conditions under which they held their land were highly unjust, depriving them of any benefit from their labour: "certainly the social conditions they had left behind had taught them that steady industry and foresight would gain them nothing." 105 There was no romantic image in the English consciousness of Irish rural happiness or well-being, particularly when Nature appeared to have turned against the Irish people by bringing the potato blight; starving children could hardly be viewed though a complacent lens of picturesqueness.

One reason that Ireland's countryside could not serve as an ideal of nature was that English observers believed that its customs and habits failed to conform to the "natural

${ }^{103}$ Ibid., 19.

${ }^{104}$ Bristol Mirror, 19th August, 1848, cited in de Nie, The Eternal Paddy, 91.

105 Gauldie, Cruel Habitations, 63. 
laws" of political economy. In Martineau's Weal and Woe in Garveloch, an Irish immigrant couple, the O'Rorys, spread their potato-growing, leisure-loving ways to the less worthy of the locals, thus exacerbating their distress when hard times hit. They serve as a counter-example to the capital-saving, hard-working Ella, by failing to understand the "natural laws" of political economy. To ignore the laws of nature is to disregard Providence. While salvation was reserved for Christians and available only through the work of Christ, God provided a more basic level of care to the wicked and the righteous alike. Providence was this divine attribute and nature was the means through which God worked. The concept of Providence permits the conflation of a personal God and an impersonal natural world. By describing natural phenomena as the working of Providence, Victorians imbued nature with moral attributes: specifically, the power to define and to encourage moral behaviour. "Evil seems to be an admonition of Providence to men to change that part of their conduct which brings on that evil." ${ }^{106}$ The O'Rorys are not helpless victims of the vagaries of disordered nature; they deserve admonition because they refuse a correct understanding of the "natural" laws and thus fail to impose the order that Providence would approve.

The idea that Nature itself would punish evil may also be seen in an 1864 article - most likely written by Godwin - in The Builder, in response to a tragic dam collapse near Sheffield, which states, "All great concentrations of misery are evils for which society is chargeable, and for which pestilence, crime, and every other resultant evil is only

${ }^{106}$ Martineau, “Weal and Woe in Garveloch,” chapter 8. 
nature's appointed punishment." ${ }^{107}$ Godwin shows here that Nature's moral force could teach a lesson not only to the poor who suffered most from famine, disease and disaster, but to society as a whole; the educated and affluent had a responsibility to bring all of society - including themselves - into conformity with the lessons of Providence.

Still, like Martineau, many English commentators saw the Irish distress as the result of Irish actions. Michael de Nie documents the idea, prevalent in some quarters in Britain, that the Great Famine was a consequence of immoral traits in the Irish national character, and that it would have a disciplinary effect on the people. ${ }^{108}$ Until the Irish learned to conform to the core values of political economy - learning to value accumulation over leisure and to increase their material aspirations to achieve the allimportant respectability - nature would surely pit itself against them.

More than just national stereotypes are at play here, however. Godwin's approval of the Spitalfields weavers and their "greenery" pointed out the "healthful recreation of the garden.” 109 In Another Blow for Life, Godwin advocates green spaces and gardens for the poor. He describes a woman growing flowers in old boxes and cracked teapots, advocates the formation of Cottage Garden societies, and praises flowers along with prints as a source of colour to lift the spirits. ${ }^{110}$ In Town Swamps and Social Bridges, flowers are one of the "bridges" whose "humanizing and refining influence" and

\footnotetext{
107 The Builder 22 (1864): 165.

108 de Nie, The Eternal Paddy, 85-87, 101

109 Godwin, London Shadows, 34.

${ }^{110}$ Godwin, Another Blow, 124-126, 95.
} 
"soothing, healthful visions" could relieve the care-worn spirit. ${ }^{111}$ Nature, then, is in its rightful place in the city when it is used for recreational purposes. The costermongers' donkeys and the Agar-town gardens were evidence of labour. Raymond Williams has written that a modern concept of nature as unspoilt, innocent, peaceful and quiet depends on "a suppression of the history of human labour." ${ }^{112}$ He has described how, in the eighteenth century, landowners improved their land by enclosing the working parts of it and cultivating them more intensely, but also by creating landscaped parks for their own recreation and aesthetic satisfaction. In this way they created an ideal of nature that obscured from view (often literally) the men and women who mixed their labour with the land to produce wealth for the gentry. ${ }^{113}$

Model dwellings made concrete a discourse about sanitation that relied on an instrumental view of nature. The natural resources they aimed to recapture for the poor were fresh air, clean water and some sunlight, admittedly crucial for life. But the necessity of continuing to provide a dividend to shareholders and thus avoid an explicit critique of liberalism meant that blocks were built high to maximise the use of expensive land, all superfluous architectural embellishment was abandoned to reduce building expenses, and there was very little open space, let alone gardens, trees or green grass around the buildings. Some complained that the model dwellings resembled prisons. ${ }^{114}$ By the time he published Another Blow for Life, Godwin himself had come to critique

\footnotetext{
${ }^{111}$ Godwin, Town Swamps, 43.

112 Williams, "Ideas of Nature," 78.

113 Raymond Williams, The Country and the City (New York: Oxford University Press, 1973), 120-126.

114 Tarn, Five Per Cent Philanthropy, 47.
} 
the grim façades and stark interiors of the model dwellings: "If we made them a little less like factories and barracks, it would go far to give an air of home to them." ${ }^{115}$ Their inhabitants enjoyed environments that were less degraded than the unsanitary courts of the slums, but they still did not have access to the environmental benefits that public parks and private squares provided in upper- and middle-class neighbourhoods. The next chapter will explore the work of Octavia Hill, which began to address this disparity.

115 Godwin, Another Blow, 62. 
Chapter 2

\section{"Bits of God's Earth"}

The Concept and Uses of Nature

in Octavia Hill's Social Housing and Conservation Work. 
Octavia Hill was "one of three great nineteenth-century women reformers." ${ }^{116}$ She was a gifted administrator, ${ }^{117}$ a scientific manager, ${ }^{118}$ and a "benevolent despot," ${ }^{119}$ who

shrewdly created a public persona to advance her causes. ${ }^{120}$ Her name, ubiquitous in her day, ${ }^{121}$ was associated primarily with practical work in improving slums and, equally, their inhabitants. She was active in lobbying for housing legislation, as well as in campaigns to preserve open spaces and in the founding of the National Trust. She counted a princess, a prime minister and a cardinal among those who listened to her practical, "common sense" advice. ${ }^{122}$ Her manner, wrote a contemporary, was sometimes cold, and she was "reckoned hard;" she refused to let compassion or friendship sway her from doing or saying what she believed was right. ${ }^{123}$ One might,

\footnotetext{
116 The other two were Florence Nightingale and Josephine Butler. George W. Liebmann, Six Lost Leaders: Prophets of Civil Society (Lanham, MD: Lexington Books, 2001), 55. Nightingale and Hill were aware and supportive of each other's work. The three were invited to Queen Victoria's Diamond Jubilee celebrations.

${ }_{117}$ Robert H. Bremner, "An Iron Scepter Twined with Roses": The Octavia Hill System of Housing Management." Social Service Review 39, no. 2 (1965): 223

${ }^{118}$ Himmelfarb, Poverty and Compassion, 212.

119 Anthony Wohl titles his chapter on Octavia Hill "Benevolent Despotism.” The Eternal Slum: Housing and Social Policy in Victorian London (Montreal : McGill-Queen's University Press, 1977).
}

120 Alexis Easley, Literary Celebrity, Gender, and Victorian Authorship, 1850-1914 (Newark; Lanham, Md.: University of Delaware Press; Rowman \& Littlefield, 2011), 176.

121 ibid. (176) reports a complaint that the "sainted name of Octavia Hill" was constantly invoked in the early twentieth century.

${ }^{122}$ Gladstone apparently advocated that she should be a member of the 1884 Royal Commission on housing, which would have made her the first woman to take such a position. Although he did not carry the day, Octavia Hill was invited to testify before the commission, which included Cardinal Manning and Lord Salisbury. Gillian Darley, Octavia Hill: A Life (London: Constable, 1990), 225-6. Princess Alice corresponded with Octavia, and visited her tenants incognito, ibid., 159-171. Lord Shuttleworth praised her "common sense:" Octavia Hill and C. Edmund Maurice, Life of Octavia Hill as Told in Her Letters, (London: Macmillan and Co., Limited, 1913), 324.

123 The writer did believe her to be unselfish and devoted to her fellow-creatures, beneath the hard manner: Darley, Octavia Hill, 162; Hill and Maurice, Letters, 301: "It is good to be wholly honest, and to say the difficult and unpopular thing, when one has to answer a question." That this strength of opinion was a matter of temperament as well as principle is indicated by a friend's remark that she "usually disliked other people's arrangement of flowers or furniture." Wohl, Eternal Slum, 189. 
then, find it curious to observe the twenty-one year old Octavia Hill writing in 1859 that she believed God had prepared her "first to love Nature and Art, second, to care that all should love Nature and Art, and third to see how to help them to do so...[with] faith to believe I can help, and oh such energy and earnestness." ${ }^{124}$ Was this merely the youthful, romantic wish of a girl as yet ignorant of her own strengths and eager to please her mentor, John Ruskin? This chapter will argue that, long after she abandoned her hopes of assisting Ruskin in his artistic and literary work, the love for "Nature and Art" that Octavia Hill had imbibed early from that great Victorian art critic and sage continued to undergird her philosophy and practice. In her work with the poor and in the wider circle of public opinion, she drew inspiration and direction from her ideas of nature. ${ }^{125}$

Like the model dwellings advocates whose work preceded and coexisted with hers, Hill believed that no good could come of ignoring the laws of the market. Like them, she esteemed the principles of sanitary reform and the importance of clean water, air, and sunlight for health. But rather than expecting these sanitary measures to work on body and soul alike, Hill argued that in order to produce a moralising effect on the poor, another set of natural resources should be introduced into their urban environments. Flowers, gardens, and green or open spaces would, she believed, have a calming and uplifting effect on those whose residences they adorned.

\footnotetext{
124 Hill and Maurice, Letters, 160.

125 In her teens and early twenties Octavia Hill was employed by Ruskin to make copies of paintings for him to use in his lectures and publications. She continued to enjoy drawing even when involved in philanthropic work. Hill and Maurice, Letters, 21 ff.; Darley, Octavia Hill, 51-53.
} 
In its interrogation of her ideas of nature, this chapter differs from most previous studies of Octavia Hill. These have tended to consider her philanthropic work, evaluating it in the context of the move towards state-provided social housing, or analysing the way she became a public figure while maintaining a persona that did not contravene Victorian gender norms. To historians who trace the development of urban social housing in Britain from early philanthropic efforts to the rise of council housing, Octavia Hill is often mentioned almost as an aside, as someone whose views were at a tangent to the overall movement. ${ }^{126}$ To those who share Hill's rejection of government intervention in the provision of social housing, she is a figure whose ideas are worth revisiting. ${ }^{127}$ Gertrude Himmelfarb appreciates the "moral imagination" of Hill and others of her ilk. Anthony Wohl offers a sympathetic portrait of Hill, which admits the many virtues of her methods and praises her sincere devotion to the poor. However, he concludes that her work had on balance a negative effect on the provision of working-class housing. It allowed political actors to remain complacent about the capacity of private enterprise to solve the urban housing crisis without state subsidies and thus delayed more effective solutions. Gareth Stedman Jones similarly evaluates her contribution as essentially negative: limited by middle-class norms and values, and trusting in "the application of moral force to political economy," her methods were not reproducible on a significant scale. ${ }^{128}$ More recent studies have resisted the urge to judge Hill as a positive or negative figure, concentrating instead on the ways in which she achieved her influence. Thomas

\footnotetext{
${ }^{126}$ Tarn, Five Per Cent Philanthropy (72-73) may be read in this way.

127 Liebmann, Six Lost Leaders, 57-86; Himmelfarb, Poverty and Compassion, 210-218.

${ }^{128}$ Wohl, The Eternal Slum, 199; Gareth Stedman Jones, Outcast London: A Study in the Relationship between Classes in Victorian Society (Harmondsworth: Penguin, 1971), 193-6.
} 
Adam, for example, traces the international impact of her housing management methods; Caroline Morrell writes on how gender shaped Hill's methods of gaining support, focussing particularly on family and friendship networks. ${ }^{129}$ This chapter will investigate Hill's concept of nature as revealed in her writing and her actions, after sketching her family background, early life and work.

James Hill welcomed his eighth daughter, the third child of his third wife, in the second year of Queen Victoria's reign. Octavia's mother, Caroline Southwood Hill, was the daughter of renowned public health reformer Dr Thomas Southwood Smith, a collaborator with Edwin Chadwick. Caroline was active in education, founding an infant school with her husband and writing many articles on theories and methods of teaching. James Hill, the son of a successful corn merchant, used his inheritance to try to better the lot of his fellow-men, and after pouring funds into several proto-socialist ventures, found himself hopelessly over-extended. Money worries and eventually bankruptcy led to his mental breakdown when Octavia was three, from which James Hill never fully recovered. Octavia's half-siblings left home and were taken in by their mothers' families. Of Caroline's daughters, the second, Gertrude, was adopted by her grandfather, $\mathrm{Dr}$ Southwood Smith; Octavia, her eldest sister Miranda, and the two youngest remained with their mother. Although he lived until 1871, James Hill remained separated from his wife and youngest children, not through lack of affection but on medical advice. Octavia barely knew her father.

\footnotetext{
129 Thomas Adam, Intercultural Transfers and the Making of the Modern World, 180o-20oo: Sources and Context (Basingstoke: Palgrave Macmillan, 2012); Caroline Morrell, 'Octavia Hill and women's networks in housing' in Gender, Health and Welfare, edited by Anne Stewart and John Digby (London: Routledge, 1996).
} 
At first, Dr Southwood Smith was able to support Caroline and her daughters in a cottage in the country. Caroline believed that young children should be educated only informally, and encouraged to follow their own interests. The girls spent most of their days outdoors in the woods and fields. Still, they were well read and even at a young age could hold intelligent conversations with adults, as Robert Browning, a visitor to Southwood Smith, would later remember. ${ }^{130}$

In 1850 Dr Southwood Smith became the permanent medical member of the Board of Health, an unpaid, full time position that necessitated him giving up his private practice. ${ }^{131}$ It is probably for this reason that he stopped supporting his daughter. The following year Caroline and her children moved to London to find work. By accepting a job managing the Ladies' Guild - a semi-philanthropic society providing employment to unskilled women and girls - Caroline managed to place her daughters in paid work under the Guild's auspices. Because the Guild was philanthropic, Caroline could support her family in a way considered respectable and appropriate for middle-class ladies. Thirteen-year-old Octavia became the supervisor of a toy-making workshop staffed by extremely poor girls, and this was her first experience with the realities of working-class life.

\footnotetext{
${ }^{130}$ Hill and Maurice, Letters, 7.

${ }^{131}$ Darley, Octavia Hill, 39.
} 
When Octavia moved from the country to the city she left behind a carefree childhood spent with family and friends. She now shouldered the burden of worries about money, heavy responsibilities at work (although more educated than they, she was younger than many of her toy-workers) and direct contact with the worst aspects of city life. Soon after she arrived, she read Mayhew's London Labour and the London Poor, which impressed upon her the sheer scale of the problems besetting working Londoners, and she became a follower of the Christian Socialists (a group of Anglican churchmen sympathetic to the Chartists), listening regularly to the sermons of F. D. Maurice. These sermons (as his son Edmund, who later married Octavia's sister Emily, put it) awakened the desire to "struggle against evils, which seemed to her irresistible." ${ }^{132}$ Although these influences would later motivate her extraordinary career, when Octavia first encountered them all simultaneously, she became depressed (a condition with which she would struggle numerous times in her life). The ugliness of London, reports Maurice, "told heavily on her spirits.” Thus even before she met Ruskin, her own personal experience convinced her that the influence of nature, beauty and the countryside was beneficial to the spirits, and that urban ugliness could harm them.

Octavia found comfort in having some living things around her. To her sister Gertrude ${ }^{133}$ she wrote in 1852, "I have usually some flowers; for the ladies are very kind in bringing me them. I have a few poor little plants that I am fond of. Then I have eleven dear little

\footnotetext{
${ }^{132}$ Hill and Maurice, Letters, 14 . The Christian Socialists had been sympathetic towards the Chartists in the 1830 , and they continued to promote a peaceful and co-operative response to social injustice, based on Christian morality.

${ }^{133}$ Gertrude was the sister adopted by her grandfather. She later married Charles Lewes, stepson of the writer George Eliot.
} 
snails. They are such darlings." ${ }^{344}$ For Octavia a little nature in one's living environment was better than none at all. On Saturdays she often led her toy-workers in expeditions to Hampstead Heath where they gathered flowers. She found the girls ignorant, not knowing the names of the flowers, and fearing there might be bears and wolves in the woods. With her sister Miranda she began to teach them the rudiments of natural history. ${ }^{135}$ Octavia was concerned that her toy-workers should not only have access to natural landscapes, but also understand and use them, and she maintained this concern in her later work.

Octavia Hill treasured her connection with the influential art and social critic, John Ruskin (1819-1900). She first met him in 1853, when he visited the Ladies' Guild. Even before this visit, he had begun to influence her through Modern Painters, the first two volumes of which had been published in 1843 and 1846. When the Guild failed in 1856 Ruskin, who had already begun to train Hill as a copyist, decided to employ her as an assistant to produce copies or artworks in watercolour or pen and ink for his lectures and books. She continued this work for more than a decade. Her letters record in detail some of the many discussions they had about art, literature, and social concerns. "We had a great deal of most interesting conversation - on French, English, and Americans on animals, of which Ruskin is very fond - on Reserve and Cordelia." ${ }^{136}$ His influence on her was undeniably profound.

\footnotetext{
134 ibid., 26. Octavia was thirteen when she wrote this.

135 ibid., 18-19.

${ }^{136}$ Ibid., 106. This letter, from Octavia's younger sister Emily, recounts a visit from Ruskin to the Hills' home in 1957.
} 
In 1864 Ruskin launched Hill on her first housing project by buying two properties in Southwark, which she managed, bringing Ruskin a five per cent return on his investment. This was a low, if safe, rate by Victorian standards, but seen as acceptable for philanthropic investment. ${ }^{137}$ Success with these ventures encouraged Hill to publish articles about the work and she gained more and more supporters willing to invest in slum properties. She repaired and improved them with the money obtained from rent, and worked hard to instil habits of cleanliness and thrift among the tenants. In the late 1870 S Hill resisted Ruskin's proposal to link his original investment with his financially risky plan for utopian rural communities, and he became angry. ${ }^{138}$ Ironically, when the two had first set up their scheme together, it had been Ruskin who initially convinced Hill that the scheme would be more valuable if it could be shown to turn a small profit, in accordance with the principles of the model dwellings companies: "Because he wishes it," she wrote to a friend, "a great desire to make it pay has seized me, almost a temptation, but it shall only help, not fetter me." ${ }^{139}$ Hill was no doubt worried that the increasingly unstable Ruskin and his cherished but impractical scheme could lose them the London houses. Despite the very public quarrel, Hill retained a high level of respect for him. They were reconciled in 1889, although they never rekindled their former close friendship. Ruskin's mental health deteriorated rapidly around this time and continued to decline until his death in 1900.

\footnotetext{
137 Tarn, Five Per Cent Philanthropy, 15.

${ }^{138}$ Darley, Octavia Hill, 195. Ruskin's utopian venture was the Guild of St George (see below, p. 70).

139 Maurice, Octavia Hill: Early Ideals, 163.
} 
In her housing projects, Octavia Hill often endeavoured to provide playgrounds, dryinggrounds for laundry, and where possible, individual or communal gardens. She expanded on this concern in the early 1870 s by campaigning to purchase and protect from development open spaces that were close to central London and within reach of the poor for picnics, excursions or simply sitting in peace. ${ }^{140}$ She worked with the Kyrle Society, founded by her sister Miranda, to bring beauty into the living environments of the poor through decorative arts, music and the preservation of green spaces. In 1895, in a logical extension of this open space advocacy, she became a co-founder of the National Trust for Places of Historic Interest or Natural Beauty. In 1905 she served on the Poor Law Commission. She continued to publish books and articles, while overseeing a vastly expanded housing management network, until her death from lung cancer in 1912.

Nature was important in all aspects of Hill's work, and so it is crucial to understand her "Nature," its characteristics and the ways she deployed it - both in concept and in physical reality - for the benefit of the urban poor. Concepts of nature may be slippery to pin down, not only because they change over time, but also because to the people who hold them they appear to be universal, unchanging and obvious. Even Ruskin, who wrote so much on nature, its relationship to art, and its beauty and truth, never put forward a single clear and specific definition of what nature actually was. ${ }^{141}$ Evocative description of natural landscapes was, however, a particular hallmark of Ruskin's writing, and through vivid word-pictures, he drew the reader's attention to the easily-

\footnotetext{
140 Octavia Hill, Homes of the London Poor. 2nd edition, 1883 (1st edition 1875). http:// www.victorianlondon.org/publications/homesofthelondonpoor.htm. (accessed 31st January, 2012), ch. 7. ${ }^{141}$ John Dixon Hunt, "Ruskin: The Design of Nature and the Transcription of Its Manuscript," Assemblage, 32 (Apr., 1997), 15-16
} 
missed details of a landscape, communicating clearly that nature was worthy of attention, even if he did not always explain why. ${ }^{142}$ Octavia Hill, despite her youthful wish to share the love of Nature and Art, was immersed in practical administrative concerns. She tended, therefore, to speak about nature principally in terms of what it could do, without stopping to define it. She did, however, pen detailed descriptions of the landscapes she encountered on her travels when writing home, as well as using description in her persuasive writing.

If Hill neglected to define nature, she was surely confident that her Victorian interlocutors shared a common understanding of the term. I have outlined some aspects of ideas of nature in chapter one. The industrial revolution brought in its wake a wave of urbanisation, creating towns and cities that were unprecedented in their huge size and explosive growth. These towns seemed to be the very antithesis of a natural landscape. The extraordinary rate of this growth set it apart from natural processes. In truth, of course, urbanisation was fuelled by industries that used natural organic or inorganic materials such as coal and water, iron and tin, cotton bolls, fleeces and wood; cities were populated not only by humans, horses, dogs, cats and perhaps cows or chickens, but less agreeably by rats, mice and a whole host of microorganisms that brought diseases such as cholera and typhus. ${ }^{143}$ Nonetheless the Victorian city, with rubbish clogging its rivers, smoke polluting its air, its slums crowded and treeless, was worlds apart from the fields and hedgerows that many of its inhabitants - like Hill herself - had known as children.

\footnotetext{
${ }^{142}$ For an appreciation of Ruskin's word-painting, see George P. Landow, Ruskin (Oxford: Oxford University Press, 1985), 29-35.

143 It was not, of course, understood before the 1880 s that these diseases were caused by living microbes rather than miasmas, that is, impure airs.
} 
Writing to a friend in 1875 during the campaign to save Swiss Cottage Fields from development Hill, tellingly, described the land as worth preserving because it "remind[ed] men and women long lost in the whirl of London, of child days and places near where they were born." ${ }^{144}$ This is a key point. Because the rural-urban migration was so recent for so many city-dwellers - either they or their parents having grown up in the countryside ${ }^{145}$ - the most salient opposition was city versus country, rather than civilisation versus wilderness, in the North American sense. ${ }^{146}$ And since the countryside was an inhabited space, rural or folk culture, in an idealised form, began to be associated or even conflated with nature. Thus not only folk traditions, but even the hierarchical and paternalistic character of traditional relationships between peasants and their landlords, appeared to be more natural - and natural often implies normative - than those shaped by modern capitalism.

Notions of the sublime and the picturesque which had been percolating for more than a century also influenced the shared Victorian concept of nature. The Romantics had

\footnotetext{
${ }^{144}$ Hill and Maurice, Letters, 333.

145 In fact, by the second half of the century, "over 80 percent of London's growth came from natural increase" and natural increase accounted for more growth than in-migration for most cities in Northern Europe: Andrew Lees and Lynn Hollen Lees, Cities and the Making of Modern Europe, 1750-1914 (Cambridge: Cambridge University Press, 2007), 133; however, perceptions rarely keep up with statistics, and the high rate of natural increase was due in part to high birth rates among young rural-urban migrants.

${ }^{146}$ Peter Thorsheim similarly distinguishes between Victorian British and contemporary American ideas of nature in his excellent chapter, "Green Space and Class in Imperial London," in The Nature of Cities, edited by Andrew C. Isenberg (Rochester, N. Y.: University of Rochester Press, 2006), 34. He convincingly characterises the Victorian ideal landscape as a garden, and uses the idea to explore how green spaces were used to control the behaviour of working-class Londoners. While my present argument - for Octavia Hill in particular - focusses on the contrast between nature as inhabited (the British view) rather than empty (the American view), the two understandings are complementary.
} 
brought nature - especially wild places - into the public gaze as a source of truth and virtue for an unsettled world. Nature in the Romantic view was vital and dynamic, not submissive or controlled. Romantics favoured landscapes that were impressive and conveyed a sense of the sublime. Romantic conceptions of nature were influential, but co-existed with an appreciation of more cultivated rural spaces. A conversation from Jane Austen's Sense and Sensibility, published in 1811, conveys the existence of these two competing views of nature. Marianne Dashwood, a devotee of rugged rocks and twisted trees, complains that "admiration of landscape scenery is become a mere jargon," while her less romantic friend Edward Ferrars confesses that he has more pleasure in "a snug farm-house... and a troop of tidy, happy villagers" than in anything that qualifies as picturesque. ${ }^{147}$

Thus, in the second half of the nineteenth century, "nature" could mean anything from forests, mountains or oceans that appeared unaffected by human activity, to wellordered villages surrounded by fields and hedgerows, to urban flower gardens. All these appeared natural in contrast to urban and industrial spaces, where nature was so transformed as to be hardly recognisable. Strongly associated with the nature/city binary was a beauty/ugliness binary. Later Victorians tended to agree with both Marianne and Edward: rugged rocks delighted the eye, but so did the snug farm-house. According to Ruskin, it was well to appreciate the picturesque in natural landscapes, but to value the "ragged misery" of the city as aesthetically pleasing showed an unacceptable lack of compassion. The capacity of the picturesque to "anaesthetise the social

\footnotetext{
${ }^{147}$ Jane Austen, Sense and Sensibility (Harmondsworth: Penguin Books, 1986. First published 1811), 122.
} 
conscience," as Malcolm Andrews puts it, had to be countered with an ethical response. ${ }^{148}$ Victorians valued built environments that appeared to be in balance with nature, but were reluctant to celebrate picturesqueness at the expense of health or happiness. When Octavia Hill had the Red Cross cottages built in Southwark, she chose a vernacular, Tudor revival style for them; she may have drawn inspiration from her travels to Nuremberg, where she had been glad that modernisation had not "[swept] away some of the beauty, and substitute[d] hideous Paris or London models." ${ }^{149}$ The decoration and individualism of the cottages made them appear more akin to organic forms than other philanthropic housing whose bleak and uniform façades seemed to symbolise the machine age. ${ }^{150}$

For some, the industrial city appeared so unnatural that they wished to reverse the tide of urbanisation that had risen in the preceding century. John Ruskin was one of the forces behind this anti-urban movement. He did not enjoy city life. This stemmed partly from personal experience: he was the only child of a strict and religious mother who allowed him no toys and virtually no companions, and his only childhood joys were the frequent travels with his family where he delighted in the different natural landscapes he discovered. ${ }^{151}$ "Sometimes I feel horror at calling this, or any place like it among these

\footnotetext{
${ }^{148}$ Ruskin, Modern Painters IV (1856) cited in Malcolm Andrews, “The Metropolitan Picturesque," in The Politics of the Picturesque, ed. Stephen Copley and Peter Garside, (Cambridge: Cambridge University Press, 1994), 288-9.

149 Hill and Maurice, Letters, 437.

${ }_{150}$ Tarn, Five Per Cent Philanthropy, 50-51 gives some examples of such façades.

${ }^{151}$ John Ruskin, Selections and Essays, The Modern Student's Library, ed. W. D. Howe (New York, Chicago etc.: C. Scribner's sons, 1918), 25-28. Mrs Ruskin was fond of Octavia Hill and Ruskin encouraged the latter's visits.
} 
accursed suburbs, "home" for ever," he wrote to Octavia Hill in $1866 .{ }^{152}$ He also deplored the inequality so evident in cities, and produced several works of social criticism that enjoyed less acclaim than his art criticism. ${ }^{153}$ In 1875 he put his anti-urbanism into practice by founding the Guild of St George, an organisation that established agricultural communities devoted to "manual labour of cultivating pure land" and "thoughtful labour of true education, in themselves, and of others." This education would not necessarily include literacy or numeracy, but "all fair arts, and sweet order and obedience of life." 154 A model community was set up near Sheffield, but it failed; returning to practising agriculture by hand had limited appeal, ${ }^{155}$ but the anti-modern strand of British thought was more enduring. William Morris, a leader of the Arts and Crafts movement and an early British socialist, was inspired by much of Ruskin's writing - especially on the inherent value of work done by hand rather than by machine - and believed that not only big cities, but the capitalist industrialism that had produced them, should be overthrown. Ruskin, Morris and other anti-modernists such as Walter Crane or Edward Carpenter held a curious status in Victorian society, standing outside mainstream opinion yet enjoying the support of large swathes of the population. Anti-urbanism was never a dominant ideology, but it was influential.

\footnotetext{
${ }^{152}$ Ruskin to Octavia Hill, April 14th, 1866, in Hill and Maurice, Letters, 219.

153 Although one of them, Unto this Last, was an inspiration to Gandhi.

${ }^{154}$ Ruskin cited in Tim Hilton, Ruskin: The Later Years (New Haven and London: Yale University Press, 2000), 307.

155 Ruskin also, through the Guild, set up St George's Museum in Sheffield, which was much more successful, and exists today as the Ruskin collection. The collection is still owned by the Guild of St George, which also owns "sustainably run farmland and fairly let property." Museums Sheffield website, http://www.museums-sheffield.org.uk/collections/ruskin-collection/ruskin-collection-frequently-askedquestions Accessed April 11th, 2012.
} 
Octavia Hill revered Ruskin, and maintained a mutual respect with Morris. Yet she was criticised by both for not going far enough in her efforts to improve the lives of the urban working classes. Ruskin, in response to Octavia's housing work and Miranda's promotion of the Kyrle Society, wrote, "My question, a very vital one, is, whether it really never enters your mind at all that all measures of amelioration in great cities, such as your sister's paper pleads for, and as you rejoice in having effected, may in reality be only encouragements to the great Evil Doers in their daily accumulating Sin?" 156 Whereas Ruskin wanted to dismantle capitalism and unmake cities, Octavia Hill preferred to work within the existing system. William Morris supported the Kyrle Society and described Hill herself as "a well intentioned, disinterested and kindly person" but believed she adopted too low a standard for living conditions for the poor. This, he argued was proof that an unjust society forced good people, if they wanted to achieve anything practical, to accept unacceptable conditions. ${ }^{157}$

These criticisms notwithstanding, it must be admitted that Octavia Hill's work achieved more practical benefit to slum inhabitants than did the Guild of St George, ${ }^{158}$ and that short of a complete overhaul of the capitalist economic system, William Morris had no concrete solutions to the housing situation. Constrained by her lack of formal education or independent means, and unwilling to stray too far from accepted gender roles, the pragmatic Hill believed that change could take root on a small scale: "until we ha[ve]

\footnotetext{
${ }^{156}$ Ruskin to Octavia Hill, June 8th, 1876, in Hill and Maurice, Letters, 341.

157 William Morris writing for Justice, his socialist paper, in July 1884, cited in Darley, Octavia Hill, 232.

${ }_{158}$ Although, as Wohl argues, if Hill's work benefitted many individuals, still compared to state intervention her methods could never provide a solution on the scale of the problem. Wohl, Eternal Slum, 195-199.
} 
cultivated to the utmost the little garden in which our house [stands], we must not cry for acres of distant land." ${ }^{159}$ In a variety of ways, she used nature - both the physical objects she categorised as natural, and the conception of nature through which these objects could convey intended meanings - to help her effect change.

Nature could be useful in transforming a city because it could improve sanitary conditions. Like George Godwin before her, Hill wrote of the importance of fresh air, sunlight, and pure water in the dwellings of the working classes. Here she followed the well-established principles of her grandfather, Dr Southwood Smith, and other sanitarians. Ruskin shared her view: in Fors Clavigera, he proclaimed that the three material things essential to life were "Pure Air, Water, and Earth." ${ }^{160}$ Until the 1880 os those who wished to improve public health in cities worked from the theoretical foundation of miasmatism, which held that disease was caused by bad air, that is, putrid emanations from decaying organic matter. If something was malodorous, it was doubtless noxious. So when people lived in crowded rooms, breathing stale air from each other's lungs, or in close proximity to foul-smelling piles of garbage, overflowing latrines or open sewers, the remedy was to make the air fresh again, by better ventilation and the removal of sources of smell pollution. ${ }^{161}$ The discovery of germ theory in the late nineteenth century was a scientific revolution that swept away miasmatism, but in fact

\footnotetext{
${ }^{159}$ Hill and Maurice, Letters, 53.

160 John Ruskin, Fors Clavigera: Letters to the Workmen and Labourers of Great Britain, Volume 1 (Boston: Dana Estes and Company, n. d.), 67.

${ }^{161}$ The sanitary reformer Edwin Chadwick was so convinced of this that he insisted, during the cholera epidemic of 1848, that sewage should be flushed away immediately; unfortunately, since the sewers flowed into the Thames, from which drinking water was drawn, his actions served to spread the disease. Francis Sheppard, London 1808-1870: The Infernal Wen (Berkeley and Los Angeles: University of California Press, 1971), 273.
} 
the most commonly-adopted public health measures underpinned by miasma theory like keeping bodies and courtyards clean and removing sewage and garbage - worked under germ theory too. The main innovation was to recognise that water was at least as important as air in disease transmission. ${ }^{162}$ When Hill took over substandard housing and began to reform it, one of the first things she did was to ventilate stairways. She disliked tall tenement blocks, which did not allow fresh air or sunlight at the lower levels. She preferred to install playgrounds, as well as drying-grounds for laundry that were spacious enough to allow the fresh air and sunlight to "purify" the clothes and linens.

For Octavia Hill, natural spaces were important for rest and relaxation. She worked herself hard, and several times her doctors ordered her away from the city to rest and regain strength. In 1877 she suffered a breakdown and spent four years away from her work, during which time she travelled and visited friends and family in Italy, Greece, and Germany as well as England and Scotland. Her letters are full of detailed and observant descriptions of the natural landscapes she encountered, indicating the value she placed on them. After this incident she made sure to take holidays, often staying with friends in the countryside, at least once a year, and in her later years she had a modest home built for herself in the countryside where she could spend time gardening

\footnotetext{
${ }^{162}$ David S. Barnes has written an excellent study of how public health activists in France assimilated the discoveries of germ theory without radically altering their practices: The Great Stink of Paris and the Nineteenth-Century Struggle against Filth and Germs (Baltimore: The Johns Hopkins University Press, 2006).
} 
and walking in the nearby hills. ${ }^{163}$ Using non-urban environments as a cure for mental and physical ailments attributed to city life is closely bound up with a view of the city as the antithesis of nature. "Through the ages the standard prescription for most urban illnesses - and perhaps as effective as more specific remedies - is retreat to some little village by seacoast or mountain - that is, restoration to a pre-urban natural environment." 164

If Hill recognised her own need for rest and nature's capacity to provide it, she knew that the working-class families with whom she interacted could also benefit. Viewing nature as a gift from God to all humankind she had strong strictures for those who attempted to profit from selling off or enclosing open spaces that had traditionally been available for common people to enjoy. ${ }^{165}$ Knowing that the poor could ill afford days off work she campaigned passionately for spaces to be preserved from development within cities, be they simple asphalt playgrounds whose only claim to being natural was the fresh air they provided, graveyards, or larger green spaces like Swiss Cottage Fields or Hampstead Heath. Yet as cheap trains became more accessible to city dwellers, she worked with the National Trust to preserve natural beauty spots as well as historic sites ${ }^{166}$ that were

\footnotetext{
${ }^{163}$ Darley, Octavia Hill, 212-3. The cottage was actually Harriot Yorke's. She was Octavia Hill's companion, colleague and friend and as she was independently wealthy she financed their joint domestic expenses.

164 Mumford, “Urbanization,” 387.

165 Octavia Hill, "Natural Beauty as a National Asset," The Nineteenth Century and After: A Monthly Review, (Dec. 1905): 935, 936

${ }^{166}$ While the National Trust is now best known for its stewardship of historic stately homes, Octavia Hill was particularly interested in preservation of natural landscapes: Darley, Octavia Hill, 309.
} 
available to most of the working classes when they could take day trips or yearly holidays.

While Hill could not follow Ruskin in his experiments with socialism, in this matter of open spaces she invoked the concept of "common land" owned and used by the community as a whole, a mediaeval custom that had been eroded over the centuries by enclosure. It is typical of Hill to hark back to preindustrial village life as a model for people living in balance with nature and with each other. However, communal ownership of land based on usage is perhaps surprisingly close to socialism for a woman who has been celebrated as an advocate of small government and of self-help for the poor. Perhaps the key lies in the concept of improvement. John Locke had argued two centuries previously that people gained the right to own land when they had mixed their own labour with it to improve it and make it more productive. Land that had been left in an uncultivated state had received no-one's labour and could therefore not be rightfully owned by one person; nature, not labour, had made the land valuable, and nature did not play favourites. Its bounties "belong to mankind in common, as they are produced by the spontaneous hand of nature." 167

Hill argued that in contrast to other rights, the right to "wander freely, and to enjoy the beauty of earth and sky" had no established money value, and as such was vulnerable to loss if the market alone was allowed to regulate land use and rights. ${ }^{168}$ She recognised

\footnotetext{
167 John Locke, Second Treatise on Government, section 26.

168 Octavia Hill, “The Future of our Commons." Fortnightly Review, 22:131 (November 1877), 631.
} 
that use-value may be worth more than exchange-value: "Is it not strange to take away free enjoyment from many, and to offer in exchange, at any money payment, a privilege to the few?" In cases where enclosure was happening informally, with no act of Parliament to regulate it, Hill called attention to the fact that although the poor who held certain rights over the commons might be compensated for the loss - for example by receiving an allowance of coal instead of the right to collect firewood - the payment may not be equivalent, and more importantly, the rights had become gifts, which "depend often on the will of squire or lord... and become a form of dole instead of a birthright." ${ }^{169}$ Hill objected strongly to the state (national or municipal) purchasing the land; the best way to protect open space, she argued, was to uphold commoners' traditional rights. In championing the commons, then, Hill remained devoted to the principle of self-help.

Over and above the physical health benefits nature could provide, Hill recognised spiritual and moral benefits. Like Ruskin, she believed that beauty was good for the soul, and that all beauty was in harmony with nature. Nature, beauty and truth were inextricable one from the other. Ruskin had written that in order for landscape painting to convey truth, it must faithfully imitate nature: "nature is so immensely superior to all that the human mind can conceive, that every departure from her is a fall beneath her, so that there can be no such thing as an ornamental falsehood." ${ }^{170}$ Morris, similarly, believed that decoration was beautiful only if it was in accord with nature. ${ }^{171}$

\footnotetext{
${ }^{169}$ Ibid., 637.

${ }^{170}$ Ruskin, Modern Painters I (2nd ed., Boston: Estes and Lauriat, 1877), 125-6. ${ }^{171}$ Marsh, Back to the Land, 189.
} 
Nature was beautiful, because it had been created by God and was an expression of his divine perfection. Hill's friend and mentor, the Christian Socialist preacher F. D. Maurice, emphasised the order of the created universe. He viewed the natural world as God's and humankind as part of, yet holding a unique position within it. Christ was the "Upholder of the true order of the world," a world which is an expression of God's love and therefore reflects harmony and order. ${ }^{172} \mathrm{Hill}$, a gifted and energetic administrator, sought to impose order on the dirt and chaos of the urban courts she managed. She did this primarily through working to inculcate better, more orderly habits and lifestyles among the tenants, believing that this was the key to improving their living conditions. ${ }^{173}$ She encouraged her fellow-workers to view the deprived and ugly courts as "bits of God's earth, which He has entrusted to them to make of them the best possible." Workers should endeavour to make the spaces reflect the beauty and order she saw in nature. Likewise, they should bring order to the inhabitants: "to take the people in the same way under their wing, and carefully respecting their independent right as tenants, to make them the best possible." ${ }^{174}$ Transforming space and transforming tenants went hand-in-hand. She co-opted nature into her efforts at moral education, taking her tenants on trips to the country, establishing gardens, holding May Queen festivals, ${ }^{175}$ distributing flowers, or planting trees and creepers wherever there was space.

\footnotetext{
${ }^{172}$ Torben Christensen, The Divine Order: A Study in F. D. Maurice's Theology (Leiden: Brill, 1973), 31-33

173 Hill, Homes of the London Poor, ch. 2

174 Hill and Ouvry, Letters, 16.

175 The revival of the May Queen festival was a pet project of Ruskin's: Marsh, Back to the Land, 11-12.
} 
Although Hill appreciated landscapes which remained wild, with little or no evidence of human presence, she often brought a sense of order to the open spaces that fell under her purview. Contemplating a churchyard that she hoped to have opened to the public Hill described it as

a capital bit of ground running down to Seven Dials, its wilderness of tall rank grass and shivering leafy trees would, even if untouched be something green to look at if the great wall which hides them were but down, and should the untidy neglected graves and green damp paving stones be put in order, and bright beds of flowers be made in the grass, should the great gates be open and a look of care and brightness given, what a possession the place would be to the residents near! ${ }^{176}$

Hill's vivid description of the churchyard returned to wilderness shows that she appreciated the beauty of wild nature. Evidently, however, "untouched" nature was not too sacred to be improved, if human well-being could benefit.

Nature, for Octavia Hill, could have an educative role, but equally it was necessary to educate people in the appropriate ways of using nature. Hill wanted fresh air, that vital natural resource, introduced into her residential courts, but families whose resources were stretched to the limits balked at paying for an extra room. She used the weight of her opinion to sway tenants' choices, as in the following incident from early in Hill's career:

One tenant -a silent, strong, uncringing woman, living with her seven children and her husband in one room-was certain "There were many things she could get for the children to eat which would do them more good than another room." I was perfectly silent. A halfpleading, half-asserting voice said: “Don’t you see I’m right, miss ?" “No,” I said; “indeed I do not. I have been brought up to know the value of abundant good air; but of course you must do as you think best-only I am sorry." Not a word more passed; but in a few weeks a second room was again to let, and the woman volunteered: "She thought she'd better strive to get the rent; good air was very important, wasn't it? ${ }^{177}$

\footnotetext{
${ }^{176}$ Hill and Ouvry, Letters, 19.

177 Hill, Homes of the London Poor, ch. 1. One might question the extent to which this incident shows Hill "respecting their independent rights as tenants."
} 
Playgrounds were not wild spaces. Whenever they were open, a supervisor watched to make sure children played appropriate games and sang appropriate songs. ${ }^{178}$ Hill hoped that the "quiet many" of working-class day-trippers would influence those inclined to drunken rowdiness to tone down their behaviour in parks and natural beauty spots. ${ }^{179}$ She envisioned those who would benefit from National Trust properties as "the artist, the professional man, and such of the public as appreciate and respect natural beauty." ${ }^{180}$ While she championed access to natural spaces for all, she reserved the right of directing their use to those she believed were qualified by dint of their education or status: "Men and women who should be free from the tendency to sacrifice such treasures to mercenary considerations, or to vulgarise them in accordance with popular cries." ${ }^{181}$

In advocating for learned guidance in managing natural spaces, Hill could take inspiration from Ruskin. In one of his volumes of art criticism, he had argued that a person contemplating a landscape painting by a great artist comes away "more than delighted, - ennobled and instructed." ${ }^{182}$ The painter, by combining his own insights with the original scene, endowed the canvas with the capacity to educate. "The simple statement of the truths of nature must in itself be pleasing to every order of mind;

\footnotetext{
${ }^{178}$ Hill and Ouvry, Letters, 21-22; Hill, Homes of the London Poor, ch. 2 179 Octavia Hill, Our Common Land (and Other Short Essays) (London: Macmillan \& Co., 1877), 2. ${ }^{180}$ Darley, Octavia Hill, 312. This is from a private letter.

${ }^{181}$ Hill, 'Natural Beauty,” 935.

${ }^{182}$ Ruskin, Modern Painters 1, 122.
} 
because every truth of nature is more or less beautiful." ${ }^{183}$ But for this beauty to produce its full beneficial effect - for it to ennoble and instruct - the average observer needed a perceptive guide to point out what was worthy of attention, and what message should be inferred from the scene. In art, this guide is the artist - or perhaps the art critic. Likewise, if the people of England were to learn directly from nature without the intervening canvas to guide them, they would need guidance in choosing the correct lessons to be drawn from the landscape.

Nature could be educative, then, because qualified individuals endowed locations with explicit meanings. Hill frequently introduced monuments, inscriptions or mottoes to her residential courts as well as to the open spaces purchased by the National Trust. The inscriptions often conveyed religious or moral values, instilled a sense of pride in Englishness associated with historical figures or events, or evoked recollections of the dead, as did the memorial to Caroline Southwood Hill on Mariners' Hill.

Using the spaces as memorials was one way of garnering support: donors might come together to purchase a site to honour a friend or family member. This was no mere marketing strategy, however. Hill believed the texts that inscribed meanings onto spaces expressed something of the identity created by human interactions with the landscape. Thus she imagined inscribing the motto "Spem, etiam illi habent, quibus nihil aliud restat" over her original court, Paradise Place, because she admired the resilient hope of

183 Ibid., 123. 
these people who often had nothing else. ${ }^{184}$ At another of her projects she organised donations to have installed an inscription in hand-crafted tiles: "Every house is builded by some, but He who built all things is God." The observer is directed to see the space not only as a human-made, built environment, but as the work of God. Yet there was another layer of meaning embedded in the inscription. Because each tile had been paid for by a different subscriber, the inscription was a way to express the participation of a group of middle-class patrons in co-creating a working-class residential space. The proclamation of shared ownership reflects tensions in the patrons' attitude towards the residents, placing the former both above and next to the latter. It both reinforces their authority over the space and conveys solidarity with the low-income residents. Thus the text had meaning in itself and as a symbolic representation of the supporters. ${ }^{185}$

Setting aside natural and historic sites through the National Trust had, for Hill, a religious significance for the nation as a whole. She described them as a "thank-offering" or a "firstfruits" offering. ${ }^{186}$ This refers to the Old Testament command to give the first part of the harvest in sacrifice, acknowledging that the food provisions had come as a gift from God, and to show gratitude for blessings received. In the Old Testament, animals or produce offered as a sacrifice had to be the best, free of any blemish, and the exceptional beauty of the territories that the National Trust sought made them similarly appropriate as a thanksgiving offering to God, who had made England rich. This wealth

\footnotetext{
${ }^{184}$ Hill, Homes of the London Poor, ch. 1. The inscription may be translated, "Those who have nothing else, have hope."

${ }^{185}$ Hill and Maurice, Letters, 297. Unfortunately, the tiles were not properly installed and fell off when affected by frost.

186 Hill, "Natural Beauty,” 939.
} 
is not to be understood as merely financial. The English landscape, that palimpsest with its layers of meaning, was if anything richer than any empty wilderness. Friar's Crag in the Lake District was beautiful, but to Hill its association with Ruskin made it more valuable still, and she was glad to have it held by the Trust and set aside as a memorial to him. ${ }^{187}$

All these ways of interacting with nature reflect a nostalgic view of the English rural village or manor as a "natural" social system which contrasted with the class conflicts and impersonal character of the capitalist city. Hill saw herself, even when poor, as a "lady" of a different class. The residents were "her" tenants, and she saw to their welfare as if they were her subjects. In a letter to her workers, she stated that the lady visitors must "take the position of queens as well as friends." ${ }^{188}$ The key, in fact, to Hill's whole housing management policy was the personal bond between worker and tenant, with mutual responsibilities and respect. It was an urbanised, idealised interpretation of the lady of the manor watching over the poor of her parish, lending succour and admonition, each belonging to the other in a way that urban capitalism did not spontaneously reproduce.

Like preindustrial English society, Octavia Hill's nature was organised hierarchically. In this she agreed with Ruskin, who had written, "Mountains are the beginning and the end of all natural scenery; in them, and in the forms of inferior landscape that lead to them,

${ }^{187}$ Ibid., 939-940.

${ }^{188}$ Hill and Ouvry, Letters, 15 . Wohl describes her inclination for a position of power in military terms, also, while acknowledging the importance of personal acquaintance between ruler and ruled: Eternal Slum, 190. 
my affections are wholly bound up." ${ }^{189}$ Yet inferior landscapes, too, had their place. Grass, for example, which seemed to have "nothing... of notable goodness or beauty," could teach lessons of cheerfulness and humility. "You roll it, and it is stronger the next day; you mow it, and it multiplies its shoots, as if it were grateful.” ${ }^{190}$ As a young girl, Hill read Ruskin's dramatic descriptions of mountains and lakes and longed to see such wonders for herself. "Do not be sorry that you cannot see beautiful places at present," he wrote to her in 1858 . "The first sensation is a thing to look forward to with hope." ${ }^{191}$ Yet Hill had grown up in the English countryside, and loved the beauty of that landscape. Even the city had its beauties: in an early conversation with Ruskin, she "said that there was as much pleasure to be found in London as in the country; that the beauties were more valued when seen, and the scraps of beauty more loved." ${ }^{192}$ In a hierarchy of nature, landscapes may be great or humble; each has its place and its value, even as it retains its distinctiveness. Hill's hierarchical nature reflects - and is reflected in - her view of a class-stratified society as natural.

Octavia Hill did not strive to begin a revolution, or to wipe out the city and all its "Evil Doers in their daily accumulating Sin." While her earnest desire was to improve the lives of the poor and give them a greater share in the nation's riches, she did not presume to sweep away the class system. She believed a bunch of flowers on the table, a creeping jenny around the front door, a walk in an urban park on a Sunday afternoon and a yearly

\footnotetext{
${ }^{189}$ Ruskin, Selections and Essays, 50. This is a passage from Modern Painters IV.

190 Ibid., 42, 44. This is a passage from Modern Painters III.

${ }^{191}$ Hill and Maurice, Letters, 107.

192 Ibid., 35 .
} 
holiday in the country could bring some measure of joy, rest and health to the poor with whom she worked. Likewise, she was convinced that a kind word, a consistent set of rules and a familiar face at the door on rent day could give hope a foothold in the worst court in the slums. Natural spaces and human relationships were, to her, the key to changing the world.

What most distinguishes Octavia Hill's "Nature," in the end, is that it is a populated space, inhabited by the living, but also by past and future generations. Soon after the death of a long-time friend and supporter in 1895, she wrote,

The place was alive with memories [...] and, as Browning says, there were both kinds, those who are to be, and to inherit the world we are trying to make fitter for them, as well as the "Wonderful dead who have passed/Thro' the body and gone." They all seemed so really among us that sometimes I could hardly think of anything tangible to be done. Truly did I think of Ruskin's passage about Association, and how places become enriched by the life that has been passed in them. You will know the passage well. ${ }^{193}$

Like most Victorians, she used the word "nature" to mean non-human living things, systems or landscapes, but she evidently regarded nature and people as intimately linked. People needed nature, and separating them from it made them less human, robbing them of physical and spiritual health. Natural spaces drew their meaning and value from the people who observed, appreciated and used them. Victorian industrial cities seemed to be the antithesis of nature, but this was not inevitable. Hill believed that well-organised leadership and sound management principles could cleanse and redeem the worst parts of the city, making them a place where both nature and humans could thrive again.

\footnotetext{
193 The place referred to here is the playground of one of Hill's original courts, and she is writing after the annual playground festival that she had organised there for many years. Hill and Maurice, Letters, 535. Unfortunately the present author does not know the Ruskin passage well and cannot cite it, since Hill did not.
} 
Geoffrey Best wrote in 1964 that Octavia Hill was "on one of history's losing sides"; Anthony Wohl found she was "neglected and unread." ${ }^{194}$ As a reformer who crusaded against state intervention in social housing, she appeared, in Wohl's phrase, "an absurd anachronism." Yet more recently she has been rediscovered as a conservationist. The Octavia Hill Society, founded in 1992, has made Hill's birthplace into an interactive museum. ${ }^{195}$ The Red Cross Gardens in Southwark, by the 1980 a a "fly-blown patch of grass" 196 and subsequently paved over, were reopened as an urban garden in 2006 to some fanfare. ${ }^{197} \mathrm{~A}$ collection of essays on Hill was published in 2012, reflecting interest in the "enduring relevance" of her conservation and urban work. ${ }^{198}$ For the centenary of her death, the National Trust offered the "Octavia Hill Awards" in categories including Nature Hero, for "individuals working for community spaces that matter to people and wildlife - in woodlands, nature reserves or orchards," and Green Space Guardians, for "a group or organisation, big or small, that has created a lot of noise (locally or nationally) to champion green spaces and places." ${ }^{199}$ The obvious implication is that Hill herself was an archetypal Hero and Guardian.

\footnotetext{
194 Geoffrey Best, Temporal Pillars (Cambridge: Cambridge University Press, 1964), 488.

195 Octavia Hill society website: http://octaviahill.org/the-octavia-hill-society.html Accessed April 26th, 2012. Significantly, the site describes Hill in the first place as a conservationist.

${ }^{196}$ Darley, Octavia Hill, 343.

197 London SE1 Community website, "Royal Reopening for Red Cross Garden,” http://www.londonse1.co.uk/news/view/2194. Accessed April 26th, 2012.

${ }^{198}$ Samuel Jones (ed.), “To the utmost of her power...” The Enduring Relevance of Octavia Hill (London: Demos, 2012).

199 National Trust website: Octavia Hill awards. http://www.nationaltrust.org.uk/get-involved/ competitions-and-offers/octavia-hill-awards/ Accessed April 26th, 2012.
} 
Jonathan Bate has argued for the utility of making "claims for the historical continuity of a tradition of environmental consciousness.” Bate suggests that by locating ideas on ecology in the writings of advocates such as the poet William Wordsworth, Ruskin, and Morris, environmental activists can build a richer set of arguments in support of their aims - even if not all nineteenth-century ideas can be recuperated: "There are aspects of later Ruskin which we will want to reject - the moral opprobriousness; the obsessive, near-paranoid tone; the element of feudalism in the alternative vision proposed - but then all readings, all uses, of literary texts are selective." ${ }^{200}$ There are aspects of Octavia Hill - such as her own moral opprobriousness, or her opposition to women's suffrage that environmentalists will no doubt wish equally to reject. Current evocations of Hill and her ideas are assuredly a selective use of her legacy, but elements that the twentieth century forgot have a new relevance to ecologists - particularly urban ones - today.

Gareth Stedman Jones sums up Octavia Hill thus: she "combined a political economy worthy of Mrs Marcet, with an emphasis on the beautification of the environment of the poor that derived from Ruskin." ${ }^{201}$ Indeed, Hill's opposition to state intervention in the housing market remained strong long after public opinion had turned away from its former trust in the powers of the free market system. Her appreciation of beauty in nature, and her belief that it should not be reserved for the affluent, had been hinted at in some of Godwin's later writings, but Hill's close connection with Ruskin and her personal appreciation of beauty in nature and art enabled her to develop more fully a

\footnotetext{
200 Jonathan Bate, Romantic Ecology: Wordsworth and the Environmental Tradition (London and New York: Routledge, 1991), 60.

${ }^{201}$ Stedman Jones, Outcast London, 15.
} 
discourse about nature that drove her campaigns for accessible green spaces. She differed, however, from Godwin in other respects. His motto, "As the homes, so the people," was the inverse of hers: she believed that unless people were retrained to correct habits, even the best living environments would become degraded. Hill's fellowworker, Henrietta Barnett, later wrote: "I thought that her demands for the surroundings of the tenants were not high enough. She expected the degraded people to live in disreputable conditions, until they proved themselves worthy of better ones, whereas it can be argued that, for most folk, decent environment is essential to the promotion of decent life.” ${ }^{202}$

Henrietta Barnett's concern for the poor, their environment, and the promotion of decent life would lead her to assist in creating an urban space on a much grander scale than Octavia Hill's courts and cottages. Chapter three will examine the ideas of nature used in the creation of this space, the Hampstead Garden Suburb.

${ }^{202}$ Henrietta Barnett, Canon Barnett, Warden of the first University Settlement, Toynbee Hall, Whitechapel, London: His Life, Work and Friends, by his Wife. 2 volumes. (Boston and New York: Houghton Mifflin Company, 1919), I:30. 
Chapter 3

\section{"Unwalled Roses in the Streets"}

Henrietta Barnett and the Hampstead Garden Suburb 
On Thursday, the fourth of May, 1907, a small crowd gathered to celebrate the beginning of work on the Hampstead Garden Suburb. Situated in North London, the development promised to be a new kind of residential community. The Suburb and others like it, declared Sir John Brunner, "stood for God's air, for light, for space, and for beauty. Coincident with that they stood for thorough business-like habits and fashions. They took no account of differences of religion or politics. Their only object was the benefit of the people." ${ }^{203}$

One imagines the shade of George Godwin nodding approvingly. The legacy of philanthropic commercialism in housing provision remained strong in the early twentieth century, with Octavia Hill's influence evident in the addition of beauty and space to the air, light and good business practices so crucial to the model dwellings companies (clean water, by this time, was no longer so scarce as to require mention). Looking at the leafy, low-density Hampstead Garden Suburb, it is easy to presume that it was a radical departure from its predecessors, the model dwellings tenement blocks. In fact, the Suburb followed the by-then-established tradition of applying a particular concept of nature to an urban space in order to counteract problems understood to arise from the unnatural character of cities. George Godwin and his contemporaries had viewed slums as unnatural because they lacked the natural resources necessary for sanitation, and because the free market seemed unable to improve them. Octavia Hill

${ }^{203}$ Hampstead Tenants Limited, Cottages with Gardens for Londoners (Letchworth: Garden City Press Ltd., 1907), 10-11; "E. B.”, Co-partnership in Housing: Being an Account of the three Hampstead Tenants' Societies form the formation of the first in May, 1907 (London: Co-partnership Publishers, 1911), 7 . 
added to this the perception that slums were unnatural because they were ugly and lacked the humanising influence of green spaces. Henrietta Barnett, an erstwhile disciple of Hill and the founder of Hampstead Garden Suburb, believed that not only the slums, but much of the housing developed to replace them, were unnatural because in them, rich and poor were artificially separated.

At the 1907 celebration, another speaker, Sir Alfred Lyttelton, evoked the image of "many communities up and down the country" in which everyone, from squire and parson to farm labourer, "lived together harmoniously" without patronage or servility. He himself had seen, he said, "the villagers and the squire and the squire's sons" playing cricket together; "if once fifty runs had been got together with the blacksmith or the grocer, there was laid the foundation of a life relationship not readily broken nor forgotten." Likewise, at Hampstead, the founders "sought to gather together in natural sympathy various classes." ${ }^{204}$ Sir Alfred, Mrs Barnett and their collaborators believed that in a community designed to harmonise with its natural surroundings, nature itself would be a "co-partner" in producing the ideal society they had imagined. ${ }^{205}$

This chapter will trace the connections between urban housing reform and the legacy of Octavia Hill, and the Garden City movement with its emphasis on town planning. It will

\footnotetext{
${ }^{204}$ Cottages with Gardens, 14-15. Lyttelton had been a very successful amateur cricketer and sportsman in his youth.

${ }^{205}$ Co-Partnership in Housing, 25. Standish Meacham argues that this vision of harmonious village life was a myth, refuting Lyttelton's claim that it still existed outside the urban centres: Regaining Paradise: Englishness and the Early Garden City Movement (New Haven and London: Yale University Press, 1999). Both Brunner and Lyttelton were members of Parliament; Lyttelton would be a lifelong director of the Hampstead Garden Suburb Trust, while Brunner's interest was the Co-Partnership Societies (see below).
} 
investigate how Hill's idea of a benevolent and ordered nature was further developed in the early twentieth century. Where she had emphasised nature's beneficial effects on individuals, her successors believed that it could heal deeper divisions in society. Furthermore, they conceived of nature as an active co-partner which, if left to work its will, would tend to produce progress and harmony while obviating the need for expensive bureaucracy.

The architect and planner Raymond Unwin would play an important role in the development of the Garden Suburb. Reading voraciously as she began working on her project, Henrietta Barnett had come across Unwin's book on domestic architecture. “That's the man for my beautiful green-golden scheme," she declared. ${ }^{206}$ Barnett had a long career in social reform behind her by the first decade of the twentieth century. Unwin was an architect, a socialist, and an active participant in the Garden City movement. In the Hampstead Garden Suburb, which they co-created, the movement for working-class housing would meet the movement for town planning. The founders would form a new type of urban environment, based on a shared concept of nature and of a national identity which drew from an idea of rural England. Yet the Suburb, attractive though it is, fell short of its original goal: providing a practical alternative to the monotonous council housing estates for working-class Londoners.

${ }^{206}$ Henrietta Barnett, The Story of the Growth of Hampstead Garden Suburb (London, 1928), 7. 
"Pretty, witty, and well-to-do," ${ }^{207}$ the nineteen-year-old Henrietta Rowland had married Samuel Barnett, a plain, earnest clergyman, in 1873. Henrietta had grown up in an affluent family, but had become disillusioned with what she saw as the selfish pleasureseeking of the middle classes while millions lived in poverty. As one of Octavia Hill's volunteer rent-collectors, she had worked in Barrett Court, Marylebone. ${ }^{208}$ Samuel had also worked closely with Hill, and when the two young reformers married he became the vicar of St Jude's, Whitechapel, a notorious slum district in London's East End. Living and working in the heart of the parish, the couple strove to know, understand and build relationships with the poor. In their many books and articles about social reform, they claimed the authority of experience and intimate knowledge of the East End. Equally, they believed they had authority to influence working-class people, labouring to bring to them "refining" influences such as education, music, open spaces and trips to the country.

The vicar was an early member of the Charity Organisation Society, and in these early years he shared with Octavia Hill the belief that "doles" demoralised the poor, providing a disincentive to work, and making it difficult for them to plan ahead. The COS, founded in 1869 , was an attempt to rationalise and systematise the various charitable organisations of the metropolis. It vetted applicants for relief on behalf of various agencies, determining which deserved help and which would be better served by being forced to face the consequences of their laziness, drunkenness or lack of thrift. The

\footnotetext{
207 Beatrice Webb, My Apprenticeship (New York: Longmans, Green and Co., 1926), 204.

208 Just off Oxford Street, Barrett's Court - renamed St Christopher's Place by Octavia Hill - is now an attractive enclave with bars, restaurants and boutiques, although in the 1870 s it was a terrible slum. In her articles Hill gave it the pseudonym "Blank Court."
} 
society was "a heterogenous collection of individuals whose reasons for participation varied greatly" and reflected older, laissez-faire liberalism alongside an emerging new liberalism, more open to collective solutions to social problems. ${ }^{209}$

The Barnetts refused to continue practices that the poor of the parish expected from their vicar, such as giving monetary rewards to those who attended church services, or indiscriminately handing out food and coal coupons. Some parishioners reacted violently to this innovation. But it did not reflect any blind faith on the Barnetts' part in the power of market forces to discipline the labour force; their notions of political economy were less orthodox than those of Godwin and Hill. They were aware that what the market deemed a fair wage might not be enough for subsistence. Henrietta, for example, in an 1886 article, described Mrs Marshall, a widow who supported her family on nine shillings a week. "And how do the rich look on these facts? 'Well, nine shillings a week is very fair wage for an unskilled working woman,' was the remark I heard;" this was the cost of wine at one meal for the speaker. The article lists in detail the amount of food needed to nourish a family adequately, as well as rent and other costs, which came to more than Mrs Marshall's wages, thus proving the rich man's opinion to be callous and ungrounded in fact. ${ }^{210}$ While the Barnetts continued to argue against doles, they did advocate regular pensions for those who could not otherwise support themselves. ${ }^{211} \mathrm{In}$ housing, Samuel Barnett recommended that the local authority consent to make land

\footnotetext{
${ }^{209}$ Stedman Jones, Outcast London, 15.

${ }^{210}$ Samuel Barnett and Henrietta Barnett, Practicable Socialism: Essays on Reform. (London: Longmans, Green \& Co., 1888), 9-10.

${ }^{211}$ The Barnetts were in favour of old age pensions as early as 1883 , and this was a source of disagreement between them and Octavia Hill, who opposed them as demoralising: Darley, Octavia Hill, 239.
} 
available for artisans' dwellings: "The community must be content to lose money by letting the ground at a lower rate. It is a form of relief which will not demoralise the poor and which perhaps is due to them on account of the neglect which has allowed such hovels to exist so long." ${ }^{212}$

Samuel and Henrietta Barnett continued their close association with Octavia Hill after their marriage, and were involved with the East End Dwellings Company, which built blocks of working-class housing from the 1880 os. ${ }^{213}$ These were managed along Hill's principles. Samuel Barnett wrote of one of these buildings:

In the name of benevolence, so as to encourage benevolence, some argue that decoration must be given up so that such dwellings may be made to pay. Probably this is a mistake in economy; it is certainly a mistake in benevolence. To treat one's neighbour as oneself is not to decorate one's own house with the art of the world, and to leave one's neighbour's house with nothing but drain-pipes to relieve the bareness of its walls. ${ }^{214}$

Several of the Barnetts' schemes echoed Hill's desire to bring not only good health, but beauty and rest, to the poor. The vicar and his wife organised concerts of classical music in the church; they invited William Morris to decorate the church interior; they arranged accommodation for city children in rural homes during the school holidays by founding the Children's Country Holiday Fund.

\footnotetext{
${ }^{212}$ Samuel Barnett writing in 1879. Henrietta Barnett, Canon Barnett, Warden of the first University Settlement, Toynbee Hall, Whitechapel, London: His Life, Work and Friends, by his Wife. 2 volumes. (Boston and New York: Houghton Mifflin Company, 1919), I:130

213 This model dwellings company built Katherine Buildings, named after Kate Potter, an associate of both Hill and the Barnetts. Kate's sister Beatrice (later Beatrice Webb) would later work as a volunteer rentcollector there. Edward Bond, who was briefly engaged to Octavia Hill in 1877, was a director of the company.

${ }^{214}$ Barnett, Canon Barnett, I:139.
} 
These ventures were informed by an understanding of the city that drew on ideas which had by now been percolating for several decades. The city was artificial; nature was its antithesis and thus the remedy for its woes. Urban society was equally artificial; citydwellers were severed from each other and from their natural roles and relationships. Samuel had written to Henrietta before their marriage that life in country towns was "the best form of life; in such close intercourse with nature we ought to live, yet against such form there is a strong feeling. Young men fly to London, so that they may be alone, freed from the criticism and scandal of neighbours; they come here and forget that the family is, and must be, the unit of society." ${ }^{215}$ To be alone, severed from nature and personal bonds, was to choose an artificial existence which was ultimately unsustainable, if not necessarily for the individual, then certainly for a healthy society.

This same city/nature binary was essential to the Garden City movement. In 1898, a Parliamentary reporter named Ebenezer Howard published a modest tract entitled Tomorrow: a Peaceful Path to Real Reform. The book proved unexpectedly popular, being reprinted in 1902 as Garden Cities of To-morrow. ${ }^{216}$ Howard had spent five years in America in the 1870s, failing as a farmer in Nebraska but arriving in Chicago just as it was rebuilding after the fire of 1871 . This was a time of explosive growth and confidence for the great city of the Great West; the young Englishman found the atmosphere invigorating and he attended lectures that stimulated his own ideas. Unlike some of his

\footnotetext{
215 Letter from Samuel Barnett to Henrietta Rowland, October 10th, 1872: Barnett, Canon Barnett, I:65. ${ }^{216}$ This edition had a new frontispiece by the socialist artist Walter Crane, who had done work for Octavia Hill.
} 
followers, he was not an anti-urbanist; "he remained throughout his life devoted to urban existence.” ${ }^{217}$

Howard's basic idea was that rather than allowing cities to continue their unchecked growth, new, planned Garden Cities should be laid out. Their populations would be limited to around 30,000, with ample areas allotted to parks and gardens in the centre, and dairy farms, allotments and fields at the periphery. There would be a series of concentric avenues, one of which would be a green belt containing churches and schools, intersected by boulevards leading to the central area. Homes for the wealthy would lie along the inner avenues close to business and administrative buildings, with workingclass cottages close to the industrial zones at the city's edge, just inside a ring railway line that would separate the built area from the farms.

This was a futuristic and modernist vision, involving substantial control over the layout of the city by a central governing body, be it the state or a private development company. In contrast to earlier Victorians who saw laissez-faire as a natural law, Howard rejected the cities that had grown up under the influence of unrestricted market forces, which had produced an "unholy, unnatural separation of society and nature." ${ }^{218}$ Nature is built into the Garden City; it is a controlled and tamed nature, subservient to human needs. Cities that grew in a quasi-organic manner through the thousands of daily decisions made by thousands of individual inhabitants were not natural but monstrous, gobbling

\footnotetext{
${ }^{217}$ Meacham, Regaining Paradise, 49.

${ }^{218}$ Ebenezer Howard, Garden Cities of To-morrow (London: Faber and Faber Ltd., 1946), 48.
} 
up land and lives like a cancerous growth. Howard quotes Lord Rosebery, the former Liberal Prime Minister: "Sixty years ago a great Englishman, Cobbett, called [London] a wen. If it was a wen then, what is it now? A tumour, an elephantiasis sucking into its gorged system half the life and the blood and the bone of the rural districts." ${ }^{219}$ The sanitary by-laws that attempted to limit health hazards while leaving builders free to pursue their own interests had only produced ugly, uniform rows of dreary terraced houses with paved roads between. Only by starting an entire new town, with communal well-being, not the pursuit of individual self-interest, as the motive force for its growth, could nature and society be brought into a harmonious relationship.

Howard is careful, however, to retain in his plan the freedom for residents, farmers and industrialists to make their own choices about their economic activities and the design of buildings. He refers to "natural competition" between farmers, which would ensure the most productive use of the agricultural land on the Garden City's periphery and thus high rents. ${ }^{220}$ But like nature, the free market is tamed in the Garden City. Since all the land is owned by the municipality, as land values increase and rents rise (thus allocating land use efficiently), these rents go into the city's coffers to provide collective benefits. This also eliminates the need for local taxation.

Although Howard appreciated the advantages and perils of both town and country, he understood them as two opposite poles. In a diagram, he depicted "Three Magnets":

\footnotetext{
${ }^{219}$ Ibid., 42. A wen is a sebaceous cyst.

${ }^{220}$ Ibid., 55.
} 
town, country and town-country, the latter being the new, utopian magnet - the gardencity - resulting from the reunion of the first two. ${ }^{221}$ "Human society and the beauty of nature are meant to be enjoyed together," Howard argued. But the conception of the garden-city as a happy medium combining the best of both society and nature depends on the underlying idea of a town/country binary. "Town and country must be married, and out of this joyous union will spring a new hope, a new life, a new civilization." In the Victorian mind, for two entities to be married, they had to be complementary yet essentially opposite. "As man and woman by their varied gifts and faculties supplement each other, so should town and country." 222

The nature that would be built into the Garden City was no longer that ambiguous, janiform nature which might pose a threat to people either through its disorder or its punitive capacities, as discussed in chapter one. Instead, Howard views a benign and symmetrical nature as the model for the city: "A town, like a flower, or a tree, or an animal, should, at each stage of its growth, possess unity, symmetry, completeness, and the effect of growth should never be to destroy that unity, but to give it greater purpose, nor to mar that symmetry, but to make it more symmetrical.” ${ }^{223}$

One reason that nature could increasingly be viewed as ordered and benign was the discovery of germ theory, which displaced miasmatic ideas about disease transmission in the 1880 os. "Germ theory transformed the way people thought about decay, for instead

\footnotetext{
${ }^{221}$ Ibid., 46.

${ }^{222}$ Ibid., 48.

223 Ibid., 76-7.
} 
of being the source of all disease, decay might be nothing more than an aesthetic concern.”224 In his study of nineteenth-century attitudes towards graveyards, Peter Thorsheim contrasts the horror with which early sanitarians like Chadwick viewed urban cemeteries with the movement to convert them into urban parks. Octavia Hill was, of course, one of those who campaigned to have churchyards opened to the public; whereas George Godwin had written earlier of the dangers to health of allowing overcrowded cemeteries in residential urban areas. Thorsheim traces the argument that instead of trying to suppress the natural process of decay or remove it from the city (as sewage had been removed by Chadwick's public works), burials should be performed in such a way as to work with, not against, nature. So instead of lead-lined coffins and stone vaults which separated corpses from the earth, some public health advocates urged that bodies be buried in biodegradable coffins - or in wicker baskets, as William Morris was at his death in $1896 .{ }^{225}$ Plants should be allowed to grow over the bodies so that the remains would be converted into vegetation which would purify the air. By cooperating with natural processes, parishes could transform their graveyards from "landscapes of disorder" where disease and immoral activity could flourish, into places which would purify the air and remoralise the people. ${ }^{226}$ Dr Benjamin Ward Richardson, a public health expert and one of the chief promoters of this view, was an early influence

\footnotetext{
${ }^{224}$ Peter Thorsheim, "The Corpse in the Garden: Burial, Health, and the Environment in NineteenthCentury London,” Environmental History 16 (January 2011): 49.

225 Ibid., 44.

${ }^{226}$ Ibid., 47-49.
} 
on Howard; his 1876 book Hygeia: A City of Health described an ideal sanitary city with limits on density and planted with trees and gardens. ${ }^{227}$

Howard's ideas were enthusiastically taken up by a group of men and women who held decidedly anti-urban and anti-modern views. For them, the Garden City represented not an equal marriage between two singly imperfect entities, so much as the application of country virtues and advantages to the problems and lacunae of urban life. ${ }^{228}$ Raymond Unwin, who with his cousin and business partner Barry Parker was to be the principal planner and architect of the Hampstead Garden Suburb, espoused these attitudes. ${ }^{229}$ If Howard was the theorist of the movement, Unwin was its "practical planner." ${ }^{230}$

Unwin was profoundly influenced in his formative years by the three most influential anti-modern thinkers of late nineteenth-century Britain: John Ruskin, William Morris, and Edward Carpenter. ${ }^{231}$ The story that Ruskin corrected his drawings when he was a child living in Oxford may be no more than a family legend, but Unwin certainly met and worked with William Morris in the late 1880 s as a young engineering draughtsman and active socialist in Manchester. Edward Carpenter (1844-1929) was a writer who combined an idealistic socialism with an interest in eastern religions, vegetarianism and

${ }^{227}$ Benjamin Ward Richardson, Hygeia: A City of Health (n. p., 1876). Available at http:// www.gutenberg.org/files/12036/12036-h/12036-h.htm. Accessed July 6th, 2013.

${ }^{228}$ Meacham, Regaining Paradise, 53.

229 Edwin Lutyens designed the grandest buildings in the Central Square, but Unwin had most influence on the overall layout. He and Parker designed many cottages and houses, although there is a long list of other eminent architects who designed residences in the Suburb.

${ }^{230}$ Mervyn Miller, Raymond Unwin: Garden Cities and Town Planning (Leicester: Leicester University Press, 1992), 1.

${ }^{231}$ Marsh, Back to the Land, 8. 
dress reform. Both Unwin and Carpenter were members of the Sheffield Socialist Society and they became close friends. Ruskin, Morris and Carpenter all believed that industrial capitalism had ruined the lives of labouring people by disconnecting them from their work and robbing them of pride in their accomplishments. All three advocated a return to manual skills and techniques and the rejection of machines for any but the most menial or degrading tasks. Carpenter's community at Millthorpe in Derbyshire was inspired in part by John Ruskin's St George's Farm at nearby Totley, where traditional agriculture was practised using manual labour and wind or water power. ${ }^{232}$

All these influential men placed great value on handwork, because they believed that mechanisation of industry had dehumanised work and left artisans and labourers open to exploitation. Bereft of joy in and control over their own labour, working people were treated by capitalists as a mere line on an expense sheet. The Arts and Crafts movement, of which William Morris was the early leader, was a response to this. Morris and his associates worked to revive traditional manufacturing techniques such as weaving, natural dyeing and embroidery, printing and bookmaking, and created designs inspired by nature or by mediaeval motifs. Morris also worked to preserve historical buildings, especially mediaeval ones, from inexpert or historically insensitive restorations or improvements.

${ }^{232}$ Miller, Raymond Unwin, 13. 
This appreciation of pre-modern art, craftwork and architecture was, then, linked to an egalitarian ideology and various shades of socialism. ${ }^{233}$ Ruskin's influential treatise, The Stones of Venice (in three volumes, 1851-53), had argued that Gothic architecture was the embodiment of Christian morality, while the Renaissance and Baroque buildings that followed expressed decadence and decline. He believed these mediaeval architectural forms retained a harmony with nature, which had since been lost. Ruskin was not the first to look back to Gothic designs in the Victorian age; it was Augustus Pugin, co-designer of the new Houses of Parliament after the fire of 1834, who sparked the Gothic revival. By thus evoking the past, Victorians responded to the rapid and immense changes of the industrial age, and attempted to retain the values which had allowed Britain to become a successful world power. The Arts and Crafts movement similarly cast its gaze backward to revive what was perceived to have been a more harmonious relationship between the various classes. It focussed not only on prestigious public buildings, but on more modest homes and their furnishings, its proponents believing that family life was key to the moral health of the nation.

The Barnetts shared this emphasis on domesticity and family relationships. In Whitechapel, they worked to strengthen families, Henrietta especially working with young mothers to teach them skills such as proper child care and good cooking. But they were concerned not only about the severing of family bonds, but of those between the classes, caused by the pressures of urban life under industrial capitalism. Henrietta and Samuel immersed themselves in the task of providing both social and spiritual

\footnotetext{
233 British Socialism had inherited the nostalgic viewpoint, however, via the transitional figure of Ruskin from Carlyle, the staunch conservative, whose views were anything but egalitarian.
} 
improvements in the lives of their parishioners, using their first-hand knowledge to challenge prevailing opinions about the poor and their problems.

The Barnetts were alarmed at the geographical separation between wealthy and poor districts in London, believing that this was the root cause of social problems and poverty. If the rich knew the poor better, they argued, they would not argue that nine shillings a week was a fair wage. If rich and poor lived in the same neighbourhood, the rich would never allow such squalour to exist. Cities were unnatural precisely because of this artificial separation of classes. The Barnetts realised that zoning resulted from the spontaneous working of the real estate market, when overcrowded neighbourhoods became less desirable for those who could afford to live elsewhere. They believed that intentional measures should be taken to alert people to the moral, social and spiritual losses that both individuals and communities suffered while property-owners profited.

Some of Henrietta Barnett's most memorable times in Whitechapel had been shared with friends of all classes when they were united not by condescension or the hope of material gain but by genuine friendship. When Kate Potter, a volunteer in one of the housing projects, married, she invited tenants, friends, and fellow-workers to the wedding, which was

....all so carefully arranged, that without fuss or patronage the coster sat side by side with the Member of Parliament, and the overworked mother enjoyed food she had not cooked, while she talked and listened to the 'quality' who had handed her to her seat. Was it bizarre, forced and fanciful? No! For all the guests, however far apart in mental and social degree, were united by their love and respect for the bride, whose thoughts and acts for everyone spelt FRIENDSHIP in imperishable letters. ${ }^{234}$

\footnotetext{
${ }^{234}$ Kate Potter was the sister of Beatrice Webb. Barnett, Canon Barnett, I: 107.
} 
Such experiences convinced Barnett that cultural and social differences between the classes could best be overcome by daily, personal interaction.

In 1884 the couple founded Toynbee Hall, a settlement house where Oxford University undergraduates could stay for extended periods in order to live among the poor, while offering university extension classes on a number of subjects. They hoped that contact with educated young men would have a refining influence on the working classes, allowing them to broaden their minds and improve their manners. Equally, the university men would be given an opportunity to know the poor better before moving on to business or government careers; thus the poor would have a vicarious voice in decisions that would affect them. Toynbee Hall was the first of these houses and was widely imitated, in Britain and beyond; its most famous daughter is probably Chicago's Hull House, founded by Jane Addams. It was situated between the prosperous West End and the squalid East End, and rich and poor had to travel to get there. Although Toynbee Hall produced a number of influential political leaders, Henrietta came to see it as no more than "an artificial protest against the massing in one locality of the poor." 235

Toynbee Hall was a secular settlement house, which aimed to bring upper and lower classes together for education and social mixing. Its lack of a specifically evangelistic mission caused a serious rift between the Barnetts and Octavia Hill: she criticised Samuel Barnett for failing to reach his parishioners on a spiritual level, despite the social

\footnotetext{
235 Henrietta Barnett, "A Garden Suburb at Hampstead," in Samuel Barnett and Henrietta Barnett, Towards Social Reform (New York: The Macmillan Company, 1909), 338.
} 
projects he led. In an 1880 letter she attributed this lack of spiritual emphasis to "Yetta's own want of real affection for the Church and a certain uncertainty in her own grasp of the facts about God" and to Samuel's shying away from criticising or disagreeing with his parishioners. ${ }^{236}$ Beatrice Webb admired Samuel Barnett's “fathomless sympathy” for all he met, but she too considered that his wife was less spiritually-inclined than he was, describing him as "an idealistic Christian without dogma" and her as "an agnostic with idealism;" "She may have been influenced by her husband's mysticism, but her native bent was a rationalist interpretation of the facts of life." ${ }^{237}$ What Webb admired made Hill uneasy. Henrietta herself would certainly have bridled at the label of agnostic, but described herself as "one of those unfortunate people who, while passionately spiritually hungry, cannot find food in the old forms and time-hallowed words, which have to me lost their significance by a reiteration, which pays no regard to changing conditions." ${ }^{238}$ Octavia Hill's criticism of the Barnetts, and her support of a rival settlement house with a specifically evangelistic mission, drove a wedge between her and her long-time friends and collaborators. During the 1880 s, the Barnetts moved further away from some of Hill's principles. As laissez-faire lost its predominance in Victorian public opinion, Samuel and Henrietta Barnett abandoned their commitment to the strict rules of the Charity Organisation Society and began to welcome some state intervention in the provision of support for the poor.

\footnotetext{
${ }^{236}$ Letter from Octavia Hill to Samuel Barnett, 6th August 1880, cited in Darley, Octavia Hill, 236.

237 Webb, My Apprenticeship, 202, 206, 204.

${ }^{238}$ Barnett, Canon Barnett, I:273.
} 
By the early twentieth century, municipalities such as the London County Council had also begun to build council housing for the poor. With their easier access to capital and loans, and no obligation to provide a profit to investors, they were often able to provide better amenities for their tenants at a lower price than philanthropic housing companies. ${ }^{239}$ Henrietta Barnett's critique of council housing was not that the local state should never be involved in the housing market; here she differed from Octavia Hill's strongly-held objection to such intervention. The problem, for Barnett, was that councils built ugly, uniform housing, "limiting a neighbourhood entirely to persons of one social class," which to her was the antithesis of a natural community. ${ }^{240}$

In 1896, the Barnetts heard from an acquaintance that the London Underground was to be extended to Hampstead. The couple had long had a weekend home here, on the outskirts of London. "We found it absolutely essential for health to get ... out of its noise and dirt." ${ }^{241}$ Whenever possible, they had brought with them parishioners from Whitechapel who were similarly in need of repose, so that the house they had named "St Jude's Cottage” became known as "St Jude's hold-all." ${ }^{242}$ Henrietta Barnett was horrified at the idea that extension of the tube line would bring with it speculative building, "rows of ugly villas" and the ruination of "the sylvan restfulness" of the spot. ${ }^{243}$

\footnotetext{
239 Tarn, Five Per Cent Philanthropy, 130.

${ }^{240}$ Barnett, “Garden Suburb,' 337.

${ }^{241}$ Barnett, Story of the Growth, 5 .

${ }^{242}$ Brigid Grafton Green, Hampstead Garden Suburb 1907-1977: A History (London: Hampstead Garden Suburb Residents Association, 1977), 5.

${ }^{243}$ Barnett, Canon Barnett, II:313.
} 
Barnett's first act was to raise money to buy an 80-acre space of heathland, to be handed over to the LCC and preserved as an open space; this, the Hampstead Heath Extension, was achieved by 1908. But her plan was more ambitious. Years before, lamenting the amount of organisational work it took to bring the classes together at Toynbee Hall, she had wished she could "buy a huge estate and build so that all classes could live in neighbourliness together" so that "friendships would come about quite naturally, and the artificial efforts to build bridges need not be made." ${ }^{244}$ As early as 1903, having obtained the option to buy a further portion of the area, in a piece published in the local newspaper, she wrote of the plan to build a garden suburb at Hampstead with "a considerable portion of it being used for houses for the industrious classes," although containing some larger houses too. ${ }^{245}$ By early 1905 , when she published an article in the Contemporary Review, that "considerable portion" had been reduced to one third of the area available.

If Barnett's early writings about the Suburb plan emphasise the working-class housing rather than the mixing of classes, it may be in part because she needed to enlist the support of Hampstead Borough Council in securing the purchase of the Hampstead Heath Extension. Making the provision of much-needed working-class housing contingent upon the preservation of the Heath Extension may have made councillors more sympathetic to the idea. ${ }^{246}$

\footnotetext{
244 Barnett, Story of the Growth, 5 .

245 Grafton Green, Hamsptead Garden Suburb, 6. ${ }^{246}$ Ibid., 6.
} 
After several years of capital-raising, organising, and publicising, work was begun in May 1907 on the Suburb, which would become Henrietta Barnett's best-known legacy. Here, she hoped, rich and poor would live together in one neighbourhood, connected to each other and to nature, in a planned community. In 1906, Parliament had passed the Hampstead Garden Suburb Act, which allowed Raymond Unwin to contravene by-laws on street width and distance between houses, unnecessary and counterproductive in a development with guaranteed low density.

Unwin's plan ensures that no building blocks another's view of Hampstead Heath, a reflection of his commitment to democracy and of the Barnetts' conviction that all classes should have access to the restful influence of nature. It shows the inspiration of the Arts and Crafts movement, with its attachment to traditional forms and building materials, mediaeval architecture, and harmony with the natural surroundings.

Buildings are often grouped around a small communal green space, and every home has at least a small garden. These gardens were crucial to the vision of harmonious living in the suburb, providing a "common interest" that would break down misunderstanding between classes: "The common interest in the Garden Suburb will be the time-honoured one of a garden, and the love of flowers and fruits and growing changing things.” 247

The gardens would have other advantages to the working-class residents. It was expected that the men would produce healthy food (while children helped and wives watched), which would provide financial and physical benefits. Henrietta Barnett had

\footnotetext{
247 Henrietta Barnett, "Science and City Suburbs," in Science in Public Affairs, edited by J. E. Hand (London: George Allen, 1906), 63.
} 
previously written about her concerns over the working-class diet. ${ }^{248}$ Over and above the physical benefits of the garden were its moral effects: by encouraging family bonds and an interest in nature, it represented "the best security against the temptations of drink and gambling." 249

Individual gardens, then, as well as the shared, open, natural space of the Heath, would be a medium through which Suburb residents of various classes would interact. By being articulated through and within a natural environment, relationships within and between families would themselves reflect the founders' ideals of natural, healthy social bonds.

Contact with nature would help people to form better relationships not only within their neighbourhood and domestic circles, but also with their nation. At the turn of the twentieth century Britain's status as the world's superpower was being challenged by new economic giants such as Germany and the United States. To preserve its Empire and its place on the world's stage, Britain needed to ensure that its own population was still worthy of them. The Barnetts were not alone in believing that knowledge of Britain's natural spaces would instil a deeper sense of British identity and attachment to the nation. Samuel Barnett had written in 1878 of the Children's Country Holiday Fund, which helped children spend time in the country: "thereby obtaining not only health, but that interest in country life which is so wanted to form real national feeling." ${ }^{250} \mathrm{~A}$

\footnotetext{
${ }^{248}$ Alison Creedon, "Only a Woman": Henrietta Barnett, Social Reformer and Founder of the Hampstead Garden Suburb (Chichester: Phillimore, 2006), 28.

249 Barnett, "Science and City Suburbs," 57.

$25^{\circ}$ Barnett, Canon Barnett, I:178.
} 
predilection for the pleasures of the country was often perceived as a particularly English trait; one French commentator attributed Britain's success in achieving civil liberty without "disorders" to "the true ballast of the body politic ... the countryfeeling." ${ }^{251}$ Henrietta Barnett appeared to believe that gardening would have universal appeal to Britons of all classes, despite at least one prior experience that proved the opposite. Supervising a cottage home for girls who had grown up in an institution, she let them choose their punishments for misdemeanours: "None surprised me so much as 'an hour's gardening' being selected, for that I had hitherto awarded as a treat!” ${ }^{252}$

Many of those active in the Garden City movement were deeply concerned with Englishness. Standish Meacham has written that the Englishness they communicated through their designs and their writings was mythical, based on an imagined preindustrial England. ${ }^{253}$ This proclivity towards looking backward, he argues, gutted Ebenezer Howard's ideas so thoroughly that the Garden City movement became much less radical than he intended. A picturesque, low-density, leafy style of suburb attached to a still-sprawling metropolis is not the revolutionary town-country magnet of Garden Cities of To-morrow, however attractive it may be.

This idea of a mythical, pre-industrial, "Merrie England" pervades the Arts and Crafts movement as well as some strands of English socialism, the Garden City movement, and

\footnotetext{
${ }^{251}$ Excerpt from Léonce de Lavergne, Rural Economy of England, Scotland and Ireland (Edinburgh and London: W. Blackwood and Sons, 1855), published as "Love of Country-Life, an English Characteristic," The Wesleyan Methodist Magazine, May 1855, 412-414.

${ }^{252}$ Barnett, Canon Barnett, I:125

253 Meacham, Regaining Paradise, 3.
} 
the Co-Partnership Tenants movement, which played an important role in the Hampstead Garden Suburb. Curiously, it appealed particularly to certain English socialists, despite the fact that this mythical ideal was made apolitical, erasing the uncomfortable facts about feudalism. It presented the village hierarchy as issuing not from economic exploitation of labourers, but from a natural, stable, harmonious social order. This order would be rediscovered if the effects of industrial capitalism could be erased. To socialists such as Raymond Unwin, the class consciousness preached by Marx was anathema. The division of society into competing classes was unnatural. In nature, every living thing had its place and function, and each one was important to the whole system; therefore people too should fulfil their place and function in society, each recognising their dependence on all the rest and showing respect for each other.

The pragmatic Octavia Hill recognised that to locate this mythical harmonious society in the Middle Ages was “a crooked way of looking at things.” On William Morris' writing she declared, "I felt the practical part very poor. I also think the miseries of the middle ages slurred over in a marvellous manner!" ${ }^{254}$ To take an imagined and idealised preindustrial England as a goal might produce very beautiful artwork, architecture and furnishings, but it was problematic as a political programme, precisely because it ignored crucial aspects of the politics that had originally produced the forms. By presenting the ideal society as natural, its politics could be ignored or obscured.

${ }^{254}$ Hill and Maurice, Letters, 317. 
Henrietta Barnett may have appreciated the social vision of Unwin and Morris, but she chose a number of her collaborators on the Garden Suburb for their business sense. "The ideals so clamorously occupying my mind had to be set out in architectural drawings and business phraseology." 255 Barnett was careful to inform her potential supporters that her scheme would be run on "a financial basis," even though her description of the amenities offered to the poor, elderly and disabled might convince readers that "the scheme is one for philanthropic effort." ${ }^{256}$ An elegantly-illustrated volume, Town Planning and Modern Architecture at the Hampstead Garden Suburb, ${ }^{257}$ similarly emphasises not only the attractiveness and comfort of the homes, but the way in which the development of the whole suburb at once according to a unified plan allowed economies of scale. Good-quality housing could thus be built at a lower cost than speculative building could offer. Howard's Garden Cities of To-morrow similarly contained several chapters of triumphant calculations proving that his scheme could provide better amenities at a lower cost, mainly because it would be built on virgin land. As the Garden City became a magnet, it would reap the benefits of increased land values itself and return them to the community in the form of public buildings and services. Barnett and her colleagues in the Hampstead Garden Suburb Trust needed to court those who could afford to pay a higher ground rent, because they intended to offer subsidised rents to companies who would build for the industrial classes.

\footnotetext{
255 Barnett, Story of the Growth, 7.

${ }^{256}$ Barnett, "Science and City Suburbs," 71.

257Raymond Unwin and M. H. Baillie Scott, Town Planning and Modern Architecture at the Hampstead Garden Suburb (London, 1909).
} 
One can trace in these attitudes the persistent idea that political economy was in some way a natural law. Laissez-faire was now decidedly out of vogue, particularly in Garden City circles, and the idea that market forces should be subject to some control, and deliberately channelled into forms whose benefit was more widely distributed, was in the ascendant. This taming of market forces corresponds to an idea of nature as increasingly ordered, benign and unified, no longer seen as chaotic or threatening, but susceptible to human management.

If the planned community was to embody natural social relationships, then, it would need new economic forms which used the potential benefits of market forces but channelled them for the good of the whole community. One company that built cottages for artisans on land leased from the Trust was the Improved Industrial Dwellings Company, a body with a long history of building model dwellings for Londoners, but which this time produced cottages with large gardens in keeping with the aesthetic of the Suburb and, from their size and the rents charged, evidently intended for the more prosperous artisans. ${ }^{258}$ There was also a new model for financing and building workingclass housing in the Garden Suburb: co-partnership. Three separate co-partnership companies operated in the Hampstead Garden Suburb, ${ }^{259}$ but all were affiliates of CoPartnership Tenants Limited and all operated on the same basic model. A number of people served as directors of two or three of the companies.

\footnotetext{
${ }^{258}$ Barnett, Story of the Growth, 20. This was a perennial problem in working-class housing; very few commercial-philanthropic societies could provide housing for the very poor, and most ended up building for the most affluent and respectable workers.

259The imaginatively-named Hampstead Tenants Ltd., Second Hampstead Tenants Ltd., and Third Hampstead Tenants Ltd.
} 
The Co-Partnership model combined an opportunity for philanthropic investment, raising much of its capital by issuing shares whose maximum dividend was five percent, with the chance for tenants themselves to have a financial stake in the development. Tenants of the three companies in Hampstead were required to own shares in the company of $£ 50$ or the equivalent of two years' rent; those who did not have the ready cash could pay in instalments. Every year, all shareholders received dividends; those who were paying instalments received the dividend as shares. In addition, any surplus profit (after paying the five per cent to shareholders) was paid out to tenants as a rentdividend. Thus the community would be motivated to keep the neighbourhood clean and attractive, knowing the residents themselves would benefit both materially and financially. ${ }^{260}$ "It is estimated that the saving that occurs through careful tenancy equals one per cent," claimed the Co-Partnership Publishers in $1911 .{ }^{261}$ This is an obvious development of Octavia Hill's basic idea; however, here, it is applied to both rich and poor residents - the Second Hampstead Tenants Ltd. offered homes at rents from 6s. per week to $£ 130$ per year ${ }^{262}$ - and thus loses some of its disciplinary character.

Samuel Barnett recognised that a safe return on investment was not always a stronger incentive for capital-raising than out-and-out charity. "People shrink from a sort of business philanthropy," he wrote in 1906 as his wife was working to raise capital for the Suburb. "Their ideal is the giver of money who receives thanks and an approving

\footnotetext{
${ }^{260}$ Barnett, "Science and City Suburbs," 67-8.

${ }^{261}$ Co-partnership in Housing, 21.

${ }^{262}$ Ibid., 18.
} 
conscience." ${ }^{263}$ However, the Co-Partnership companies did, in the years before the Great War, raise the money to build the planned housing on the areas they had leased.

In the early years - from 1907 when the first cottages were built, to the outbreak of war in 1914 - residents enjoyed the flourishing community spirit and neighbourliness of which Henrietta Barnett had dreamed. Later, old residents reminisced about "the days which they recall[ed] as companionable, friendly and free." Kathleen Slack names proximity to bus and tube routes as the most important pull for residents, but she does write of the "air of innocent gaiety" conjured up by pageants, festivals and maypole dancing. ${ }^{264}$ Some of those who were drawn there in the early years were typical Garden City "crazy, crankish, freakish people...rationalists and vegetarians, suffragettes, Fabians and Theosophists," as a retrospective piece in the Times put it fifty years later; "the longbearded, sandalled brigade," as an elderly resident recalled. Raymond Unwin's family dressed in ethically (and manually) produced "Ruskin flannel." ${ }^{66}$ The Institute, a community building in the centre of the Suburb, offered a plethora of classes and activities, including the Horticultural Society, so dear to the founders' hearts. The Club House, in the northern part of the Suburb, catered to more working-class tastes.

\footnotetext{
263 Barnett, Canon Barnett, II: 319.

${ }^{264}$ Kathleen M. Slack, Henrietta’s Dream: A Chronicle of Hampstead Garden Suburb (London: 1982), 34-36.

265 “A Garden City Recalled," The Times, 5 July 1957, and an anonymous resident, cited in Slack, Henrietta's Dream, 42-43. The early residents of the first Garden City, Letchworth, had a similar reputation. "Ruskin flannel" was so-called because it was he who had revived a cottage industry for handwoven textiles, popular among people who shared his ideas about industrial society.
} 
But the mixing of classes in the Suburb was never as complete as Henrietta Barnett liked to assert, even before the Great War and the inflation of the 1920 s put financial pressures on the various trusts and companies, and essentially priced the working classes out of the market. While the Suburb itself contained both larger and more modest homes, these were never next door to each other. The northern section of the "old suburb" ${ }^{266}$ was designated as the working-class area, with cottages and the Club House close by. The best views of Hampstead Heath and the closest proximity to the Heath Extension were reserved for the larger mansions in the southern part of the Suburb. Henrietta Barnett wanted the classes to have contact with each other, yet she had no thought of abolishing hierarchy. ${ }^{267}$ Classes could remain distinct while maintaining harmonious relationships; indeed, specialisation and variety was more true to nature than any uniform egalitarianism.

It was important to Henrietta Barnett that people marginalised by society should benefit from living as part of a community. In addition to the working-class cottages, by 1919 there were homes for war widows, single working women, convalescents, elderly people and workhouse children. Barnett had long been a proponent of "scattered homes" to keep children out of institutions, and the four cottages set aside as such in the Suburb fit her principles. Charity, she had come to believe, should be offered less self-consciously, with fewer arbitrary rules and more contact with the surrounding community.

I think, after vast experience, that 'doing good' is a pernicious practice, though it is usually an early infirmity of all noble minds. But the young, the weak, the ill, the ignorant, need

\footnotetext{
${ }^{266}$ That is, the first area to be set out; further tracts of land were obtained and developed in the following decades.

${ }^{267}$ Meacham, Regaining Paradise, 8.
} 
the influence of a wide sky, a clear air, of flowers and beauty; they require the education of good things 'in widest commonalty spread' - or unwalled roses in the streets - and so pains have been taken to establish them on the estate. ${ }^{268}$

Barnett's ideal, then - and one shared by the supporters of the Garden City and CoPartnership movements - was to create a community in which nature itself provided those advantages which were rightly enjoyed by all, with a minimum of elaborate and costly social machinery to support it. When buildings and streets were designed to reflect and benefit from the natural surroundings rather than maximise profit, they would promote not only better health but also better domestic life; this would spill out into the community as neighbourly relationships grew up spontaneously. In addition, a financial set-up that provided incentives for both tenants and investors to build and maintain a pleasant environment would serve all, without the "demoralising" effects of doles, or any concerted effort to transfer resources from rich to poor in an artificial, intentional way.

The belief that nature itself would tend, if managed wisely, to bring about social progress and harmony, relied upon the newer and more optimistic view of nature as benevolent and unified. Just as adherents of laissez-faire earlier in the century believed that the natural laws of political economy worked best when people worked in accordance with them rather than trying to distort them, so these early twentieth-century suburbbuilders believed that knowing nature better, and creating communities that emulated natural models, would bring about a prosperous, healthy and harmonious society

268 Barnett, Canon Barnett, II: 318. 
without the need for onerous and artificial intervention. Their confidence, however, was misplaced, at least in this instance.

In 1928, Henrietta Barnett reflected on the development of the Hampstead Garden Suburb over two decades. Physically, she judged, the Suburb looked just as she had dreamed it would, with trees arranged between houses to provide an attractive colour scheme, the church spire crowning the hill, and homes arranged in pleasing asymmetry along the curvilinear streets. However, "on the deeper side I may perhaps confess to some disappointment.” Distinguished visitors from all over the world came to visit the Suburb as an excellent example of town planning. The residents themselves, however, did not seem to appreciate the underlying principles designed to take root and flourish there. Individuals were often willing to improve or modify their own property at the expense of the whole community, wanting to add a garage or an extension to their home without caring that a neighbour's view would be blocked. "Then I wonder if enough of the residents make real attempts to know intimately the classes which do not belong socially to their own," she lamented. ${ }^{269}$ To the end of her life Barnett deployed her considerable influence and forceful personality to lobby for more provision for the disadvantaged, but to less and less avail as the Suburb's wealthier residents resisted the benevolent authoritarianism of the Trust and rallied to protect their property values.

The Hampstead Garden Suburb, although beautiful, is no longer the embodiment of Henrietta Barnett's vision, if indeed it ever was. It has, "through the workings of the

\footnotetext{
${ }^{269}$ Barnett, Story of the Growth, 76.
} 
property market, inevitably become a wealthy community, with many of the smaller artisans' cottages now supporting ownership of two or three cars." ${ }^{270}$ It is "a middleclass enclave whose residents wish more to preserve their standards of taste, comfort and privacy than to promote Henrietta's dream that all classes of society should enjoy the benefits of education, leisure and social opportunities in a beautiful and healthy environment.” ${ }^{271}$ Like other Victorian housing reformers, Henrietta Barnett had worked hard to integrate the power of capitalism into a scheme whose heart was social justice, but had been unable, in the end, to tame that power and make it subservient to her goals.

However, the idea of nature that housing reformers had helped to develop remained powerful. The growth of suburbs in the twentieth century, and the conservation movement, would rely upon the notion that nature was benign, a source of truth and virtue beyond human divisions or culture; that nature was at its best when tamed by humans, but not distorted or destroyed by them; and that peaceful recreation was the ideal way to enjoy it.

\footnotetext{
270 Mervyn Miller, “The Saga of the 'Suburb Salubrious,'” Planning History 14:3 (1992), 5. ${ }^{271}$ Slack, Henrietta's Dream, 116. By 1972, only $8 \%$ of the residents were manual workers, compared to a national average of 65\%: Ibid., 44.
} 
Conclusion 
On a bright, blustery day in early May, 1907, Henrietta Barnett posed, commemorative spade in hand, for a photograph to mark the cutting of the first sod of the Hampstead Garden Suburb. Flanked by flower-laden, white-clad little girls, Mrs Barnett dug into the turf, as assorted dignitaries looked on and spectators watched from behind a cordon. Then she returned to the platform where, earlier, children had danced around the Maypole, to add her speech to those of the distinguished men who shared her enthusiasm for the garden suburb scheme. They had met together, she declared, "to make a bit of God's earth beautiful for generations ahead.” Little Winnie Hutchings, presenting Mrs Barnett with a "handsome basket of flowers," recited a poem in her honour, evoking a future time "when, at peace with God, and peace with man, and peace with Nature's grace, the people here in happier homes will dwell..." ${ }^{272}$

Four decades after Octavia Hill's first May Day festival in Freshwater Place, despite the personal and ideological differences that had come between the old friends and fellowworkers, her influence was palpable in Henrietta Barnett's cherished scheme for a Garden Suburb, although she herself took no personal role in it. ${ }^{273}$ The values of innocence and purity, of health and wholesome pleasures, that the May festival seemed to embody, made it an apt symbol of the aims of urban reformers. At the same time, the festival's connection with the natural world and its endurance through changes of

\footnotetext{
${ }^{272}$ Cottages with Gardens for Londoners, 7-17.

273 Barnett had indeed asked Hill for advice three years previously, only to be politely rebuffed: "I fear I must not think of looking at 'Garden Suburb' questions. I have more than I should do to follow the work before me, and I dare not turn to other problems and ideals." Letter from Octavia Hill to Henrietta Barnett, 1904. Darley, Octavia Hill, 323. Hill's sister and brother-in-law were, however, present at the sod-cutting ceremony.
} 
religion and regime made it, and by extension the projects of its promoters, appear to be outside the petty concerns of Victorian and Edwardian politics.

Geographer and political ecologist Erik Swyngedouw, referring to twenty-first century ecological debate, has critiqued the way in which the concept of sustainability has become "postpolitical." ${ }^{274}$ Ideas about sustainability are based on an underlying view of nature as singular, orderly and benign, an harmonious ideal which we all must aspire to attain. Yet, Swyngedouw argues, this nature does not exist except as a cultural construct. Every class, every ethnic group, each gender has its own idea of what is and is not natural. There exists a multiplicity of natures; when nature is understood to be singular, it merely means that one, dominant group's favoured conception of nature attains hegemony. "A politics of sustainability, predicated upon a radically conservative and reactionary view of a singular - and ontologically stable and harmonious - Nature is necessarily one that eradicates or evacuates the 'political' from debates over what to do with natures.” ${ }^{275}$ Everyone declares support for sustainability, Swyngedouw remarks, from Greenpeace to the Pope to George W. Bush. But do they all want to sustain the same thing?

Housing reformers who wished to fix the city's problems by reintroducing nature to environments that they understood to be artificial believed that nature was beyond politics and class divisions. They failed to recognise the extent to which their "natures"

\footnotetext{
274 Erik Swyngedouw, "Impossible 'Sustainability' and the Postpolitical Condition,” in The Sustainable Development Paradox: Urban Political Economy in the United States and Europe, ed. Rob Krueger and David Gibbs, 13-40 (New York: Guilford Press, 2007).

275 Ibid., 23.
} 
were influenced by the norms of the middle class, or even by their own personal tastes and biases. One might ask, for example, to what extent the promotion of the May Queen festival was driven by Ruskin's own romantic (and probably sexual) ideal of the preadolescent girl as pure and innocent, an ideal which connected well with Victorian notions of sexuality, femininity and childhood, but which in Ruskin's personal life led to a failed marriage and personal grief.

This is not to say that their intended beneficiaries rejected all these renaturalisation efforts. On the contrary, the children of Freshwater Place used their supervised playground, and parents sent their offspring on rural homestays through the Barnetts' Children's Country Holiday Fund; a working-class woman from Sheffield sent money to support the National Trust, even though she herself had never been able to visit its renowned beauty spots. But because the natures that were preserved or created in the city were provided not by working-class people, but by upper- and middle-class activists and investors, the ways in which these spaces could be used had to conform to the patrons' preferences. So costermongers were provided with basement or ground-floor storage for their goods and animals in model dwellings, and discouraged from keeping them in their living spaces; but in general they preferred their old, inferior homes shared with their animals to cleaner but controlled rooms in the new blocks. Gardens that looked attractive and gave the impression of recreation rather than labour were encouraged. The nature of the privileged classes was privileged in the city. 
In the early days of housing reform, when sanitary concerns were most pressing, nature was brought into the slums under the auspices of science. Pure water, air and sunlight would drive away the decaying organic matter that was believed to be the source of disease. Public health was the main concern, and health science provided the framework of the discourse. But even at this point, reformers expressed moral concerns. They conflated physical and moral impurity, dirty bodies and immoral acts. When children committed petty crimes, or girls acted improperly, it was presumed that this was an inevitable consequence of growing up in a degraded environment. Like fever and plague, immoral behaviour was a symptom of urban sickness. As the century progressed, and overall public health improved without an automatic drop in crime or other undesirable activity, those working to improve urban life for the poor began to write more about the social and spiritual benefits of nature, such as repose, recreation, moral grounding, and social harmony. They created natural spaces that conformed to these prescribed uses of nature. Yet even as they did so, they reified these natures as "Nature," a singular, eternal, stable and beneficent entity. To do so is to shut down debate; as J. S. Mill recognised, when a social construction (or social science) purports to be a law of nature, other alternatives cannot be proposed.

Swyngedouw also critiques the "apocalyptic imaginary" that characterises public debate on sustainability today, and that "forecloses asking serious political questions about possible socioenvironmental trajectories." ${ }^{276}$ This thesis has shown that this is nothing new. Fears of disease, of moral decline, of class divisions gave rise to shocking narratives

${ }^{276}$ Ibid., 13. 
about stinking courts, incestuous relationships, and the physical decline of young men that would lead to the loss of the Empire. George Godwin wrote in the style of a professional, not a penny dreadful, but in doing so he aimed to impress upon his readers the gravity of the situation and to provoke action. ${ }^{277}$

When Sir John Brunner, therefore, at the Hampstead Garden Suburb sod-cutting ceremony, claimed that those present had gathered without regard to religion or politics, concerned only for the "benefit of the people," he failed to recognise the political project in which they were participating. If the Garden City movement was not aligned with any one party, neither was it apolitical; a specific idea about how society should be organised and governed underlay the whole scheme. But by designating gardens, roadside trees, Arts and Crafts architecture and hierarchical social harmony as "natural" Barnett and her allies offered their plan with no room for questioning or negotiation.

Similarly, because "Nature" had both physical and social attributes and both were seen as universal, it could render invisible tensions between contradictory political positions. Octavia Hill, who refused ever to become involved in party politics, believing that this was not an appropriate sphere for women, probably considered herself an apolitical figure. Through a discourse about universal nature, she could adhere dogmatically to the principles of commercial philanthropy and laissez-faire by resisting any state or private handouts that would distort "natural" market relations, yet at the same time oppose the

\footnotetext{
277 As women, Octavia Hill and Henrietta Barnett may have had less freedom to write about shocking things.
} 
commodification of open spaces by appealing to the idea of the commons, a precapitalist form of land tenure.

The high tide of laissez-faire receded from the $1880 \mathrm{os}$, and market forces were no longer relied upon to organise society for the benefit of all citizens without state intervention. "Nature" represented a way to provide universal social amelioration without the heavy cost of (state or private) bureaucracy. An ambiguous, potentially threatening nature could not serve this purpose; this thinking relied upon a conception of nature as ordered and benign, with an innate tendency towards progress and improvement. Within this conception, the threatening visage of chaotic nature, manifested in epidemics, natural disasters, or famines, exists only or predominantly because human activity has distorted and deformed natural processes. Indeed, the city itself came to embody the threatening side of nature: described as a tumour, an illegible jungle, or a parasite, it was the antithesis of a singular and benevolent Nature, an artificial entity described in organic metaphors inherited from the older dual concept of nature.

This thesis has explored the connections between slowly shifting ideas of nature, and political and economic realities. It has shown how ideas about political economy and about cities shaped and were shaped by concepts of nature as they were tossed about in the ring of public discourse. For the sake of brevity it has confined its discussion to England, and almost entirely to London. However, the discourses deployed by Godwin, Hill and Barnett were not specifically English; they used ideas from across the Channel and across the Atlantic, too. Godwin in particular studied the work of Haussmann in 
Paris in the 1850 s and 1860 s and concluded that the suffering he caused to the Parisian poor was not a price worth paying for wide boulevards and attractive buildings. In turn British reformers influenced work abroad: Octavia Hill Societies were set up in Philadelphia, Amsterdam and Germany; Garden Cities or suburbs sprang up across the world, particularly in the United States and Germany, where Ernst May's developments outside Frankfurt are a notable example. Even Le Corbusier in his early career designed garden suburbs before repudiating Parker and Unwin's principles in favour of modernism. ${ }^{278}$ Further work could fruitfully explore these transatlantic and European connections.

Equally, the thesis has focussed on a particular set of historical actors who, when confronted with the intractability of urban problems to the supposedly improving forces of the free market, concluded that it was the city, not the market itself, that was unnatural. Yet the failure of the market to eliminate dire poverty in the mid-nineteenth century surely led to the decline of the laissez-faire consensus in the subsequent decades. Further work could look at more radical activists to see whether they used concepts of nature in their discourse. Since working-class voices are harder to recover than the prolific publications of the Victorian middle classes, this thesis has not attempted to sketch a distinctively working-class view of nature; this would also be a worthwhile line of inquiry.

${ }^{278}$ Miller, "The Suburb Salubrious," 4. 
"The key political question," argues Erik Swyngedouw, "is one that centers on the question of what kinds of natures we wish to inhabit, what kinds of natures we wish to preserve, to make, or, if need be, to wipe off the surface of the planet (e.g. the HIV virus), and on how to get there." ${ }^{279}$ Recognising that the "Nature" we have inherited is not an eternal and unchanging ideal, but one with which we can choose how to interact, makes discussion about sustainability more democratic.

Godwin, Hill, Barnett and the other actors who have appeared in this study may never overtly have posed the question of what kinds of natures should be preserved; they all appear to have believed that their concept of nature was universal. Yet by their actions and words they created in British towns the kinds of natures they believed all citizens should inhabit, while attempting to wipe off the surface of the planet natures that were harmful or that appeared to them distorted and unhealthy. This thesis has, it is hoped, contributed to an understanding of the malleability of conceptions of nature as well as their intimate connection with notions of class, and of political economy, as they were expressed in nineteenth-century cities.

${ }^{279}$ Swyngedouw, “Impossible Sustainability,” 23. 


\section{Bibliography}

\section{Primary Sources}

$\underline{\text { Books }}$

Austen, Jane. Sense and Sensibility. Penguin Classics edition. Harmondsworth: Penguin Books, 1986. First published 1811.

"E. B.", Co-partnership in Housing: Being an Account of the three Hampstead Tenants' Societies form the formation of the first in May, 1907. London: Co-partnership Publishers, 1911.

Barnett, Samuel and Henrietta Barnett. Practicable Socialism: Essays on Social Reform. London: Longmans, Green \& Co., 1888.

Barnett, Samuel and Henrietta Barnett. Practicable Socialism: New Series. London: Longmans, Green \& Co., 1915.

Barnett, Samuel and Henrietta Barnett. Towards Social Reform. London: T. Fisher Unwin, 1909.

Barnett, Henrietta. Canon Barnett, Warden of the First University Settlement, Toynbee Hall: His Life, Work and Friends, by his Wife. Boston and New York : Houghton Mifflin, 1919. 2 volumes.

Barnett, Henrietta. The story of the growth of the Hampstead Garden Suburb, 1907-1928. London: Hampstead Garden Suburb Trust, 1928.

Beames, Thomas. The Rookeries of London. London: F. Cass, 1970 (reprint of 1852 edition).

Eliot, George. Middlemarch. Harmondsworth: Penguin Books, 1965. First published 1871-2.

Godwin, George. Another Blow for Life. London: Wm. H. Allen \& Co., 1864.

Godwin, George. London Shadows: A Glance at the "Homes" of the Thousands. London: George Routledge \& Co., 1854.

Godwin, George. Town Swamps and Social Bridges. London: Routledge, Warnes \& Routledge, 1859.

Hampstead Tenants Limited Cottages with Gardens for Londoners. Letchworth: Garden City Press Ltd., 1907.

Hill, Octavia. Extracts from Octavia Hill's “Letters to Fellow-Workers” 1864 to 1911. Compiled by Elinor Southwood Ouvry. London: The Adelphi Book Shop, 1933. 
Hill, Octavia. Homes of the London Poor. 2nd edition, 1883 (1st edition 1875). http:// www.victorianlondon.org/publications/homesofthelondonpoor.htm. (accessed 31st January, 2012)

Hill, Octavia, and C. Edmund Maurice. Life of Octavia Hill as Told in Her Letters. London: Macmillan and Co., Limited, 1913.

Hill, Octavia. Our Common Land (and Other Short Essays). London,: Macmillan \& Co., 1877 .

Howard, Ebenezer. Garden Cities of To-morrow. London: Faber and Faber Ltd. 1946. First published 1902.

de Lavergne, Léonce. Rural Economy of England, Scotland and Ireland. Edinburgh and London: W. Blackwood and Sons, 1855. Published as "Love of Country-Life, an English Characteristic," The Wesleyan Methodist Magazine, May 1855, 412-414.

Malthus, Thomas Robert. An Essay on the Principle of Population. London: J. Johnson, 1798. Available at http://www.econlib.org/library/Malthus/malPop2.html\#Chapter \%20IV. Accessed July 4, 2013.

Marcet, Jane. Conversations on Political Economy (6 ${ }^{\text {th }}$ ed.) London: Longman, Rees, Orme, Brown and Green, 1827 (first published 1824).

Martineau, Harriet. Illustrations of Political Economy: Selected Tales, edited by Deborah Anna Logan. Peterborough, Ontario: Broadview Editions, 2004.

Martineau, Harriet. "Weal and Woe in Garveloch.” In Illustrations of Political Economy (3rd edition), in 9 volumes. London: Charles Fox, 1832. Available at http:// oll.libertyfund.org/title/1690/143123. Accessed July 4th, 2013.

Masterman, C. F. G. The Heart of the Empire: Discussions of Problems of Modern City Life. London: T. Fisher Unwin, 1901.

Maurice, Emily Southwood Hill. Octavia Hill, Early Ideals, from Letters. London,: G. Allen \& Unwin, 1928.

Mill, John Stuart. Autobiography. Indianapolis: Bobbs-Merrill, 1957 (first published 1873).

Mill, John Stuart. Principles of Political Economy with some of their Applications to Social Philosophy, edited byWilliam J. Ashley. London; Longmans, Green and Co. 1909 (first published 1848).

Richardson, Benjamin Ward. Hygeia: A City of Health. n. p., 1876. Available at http:// www.gutenberg.org/files/12036/12036-h/12036-h.htm. Accessed July 6th, 2013.

Ruskin, John. Fors Clavigera: Letters to the Workmen and Labourers of Great Britain, vol. 1. Boston: Dana Estes and Company, n.d.

Ruskin, John. Modern Painters I. 2nd edition. Boston: Estes and Lauriat, 1877. 
Ruskin, John. The Works of John Ruskin. Sir Edward Dyas Cook and Alexander D. O. Wedderburn (eds.) London: G. Allen, 1902-1912. 39 vols.

Ruskin, John, and Frederick William Roe. Selections and Essays, The Modern Student's Library, Ed. By W. D. Howe. New York, Chicago etc.: C. Scribner's Sons, 1918.

Smith, Charles Manby. Curiosities of London Life; or, Phases, Physiological and Social, of the Great Metropolis. London: F. Cass, 1972 (first published 1853).

Town Planning and Modern Architecture at the Hampstead Garden Suburb, with contributions by Raymond Unwin and M. H. Baillie Scott. London: T. F. Unwin, 1909.

Webb, Beatrice. The Diary of Beatrice Webb, Vol. 1: 1873-1892. Edited by Norman and Jeanne MacKenzie. Cambridge, Mass: Belknap Press, 1982.

Webb, Beatrice. My Apprenticeship. New York: Longmans, Green, and Co., 1926.

\section{Articles and Chapters}

Barnett, Henrietta. "Science and City Suburbs." In Science in Public Affairs, edited by J. E. Hand, 45-74. London: George Allen, 1906.

Barnett, Henrietta. "Town Children in the Country." The Nineteenth Century: A

Monthly Review 48:281 (1900): 100-107.

Hill, Octavia. "Natural Beauty as a National Asset." The Nineteenth Century and After : A Monthly Review 58: 346 (1905): 935-941.

Hill, Octavia. "The Future of our Commons." Fortnightly Review 22:131 (November 1877): 631-641.

\section{Websites}

Octavia Hill society website: http://octaviahill.org/the-octavia-hill-society.html Accessed April 26th, 2012.

London SE1 Community website, "Royal Reopening for Red Cross Garden,” http:// www.london-se1.co.uk/news/view/2194. Accessed April 26th, 2012.

National Trust website: Octavia Hill awards. http://www.nationaltrust.org.uk/getinvolved/competitions-and-offers/octavia-hill-awards/ Accessed April 26th, 2012.

\section{Secondary Sources}

Monographs and Collective Works 
Adam, Thomas. Intercultural Transfers and the Making of the Modern World, 180o-200o. Basingstoke: Palgrave Macmillan, 2012.

Barnes, David S. The Great Stink of Paris and the Nineteenth-Century Struggle against Dirt and Germs. Baltimore: The Johns Hopkins University Press, 2006.

Bate, Jonathan. Romantic Ecology: Wordsworth and the Environmental Tradition. London and New York: Routledge, 1991.

Berg, Maxine. The Machinery Question and the Making of Political Economy, 1815-1848. Cambridge: Cambridge University Press, 1980.

Best, Geoffrey. Temporal Pillars. Cambridge: Cambridge University Press, 1964.

Bresler, Fenton. Napoléon III: A Life. New York: Carroll and Graf, 1999.

de Certeau, Michel. L’invention du quotidien I: arts de faire. Paris: Gallimard, 1990.

Christensen, Torben, The Divine Order: A Study in F. D. Maurice's Theology. Leiden: Brill, 1973.

Colley, Linda. Britons: Forging the Nation 1707-1837. New Haven and London: Yale University Press, 1992.

Creedon, Alison. Only a Woman: Henrietta Barnett, Social Reformer and Founder of Hampstead Garden Suburb. Chichester: Phillimore, 2006.

Creese, Walter. The Search for Environment: The Garden City Before and After. New Haven: Yale University Press, 1966. Expanded edition, 1992.

Cronon, William. Nature's Metropolis: Chicago and the Great West. New York and London: Norton, 1991.

Cronon, William, (ed.). Uncommon Ground : Toward Reinventing Nature. 1st ed. New York: W.W. Norton \& Co., 1995.

Darley, Gillian. Octavia Hill: A Life. London: Constable, 1990.

Dumont, Marie-Jeanne. Le logement social à Paris 1850-1930: Les habitations à bon marché. Liège: Mardaga, 1991.

Easley, Alexis. Literary Celebrity, Gender, and Victorian Authorship, 1850-1914.

Newark; Lanham, Md.: University of Delaware Press; Rowman \& Littlefield, 2011.

Gandy, Matthew. Concrete and Clay: Reworking Nature in New York City. Cambridge, Mass. and London: The MIT Press, 2002.

Gauldie, Enid. Cruel Habitations: A History of Working-Class Housing 1780-1918.

London: George Allen and Unwin, 1974. 
Grafton Green, Brigid. Hampstead Garden Suburb 1907-1977: A History.London: Hampstead Garden Suburb Residents Association, 1977.

Harvey, David. Justice, Nature, and the Geography of Difference. Oxford: Blackwell Publishers, 1996.

Harvey, David. Social Justice and the City. Athens and London: University of Georgia Press, 2009. Revised edition: first published 1973.

Hawkins, Mike. Social Darwinism in European and American Thought, 186o-1945. Cambridge: Cambridge University Press, 1997.

Hilton, Tim. Ruskin: The Later Years. New Haven and London: Yale University Press, 2000.

Himmelfarb, Gertrude. The Idea of Poverty: England in the Early Industrial Age. New York: Alfred A. Knopf, 1984.

Himmelfarb, Gertrude. Poverty and Compassion: The Moral Imagination of the Late Victorians. 1st Vintage Books ed. New York: Vintage Books, 1992.

Hughes, J. Donald. What is Environmental History? Cambridge, UK: Polity Press, 2006.

Joseph Jacobs, The Fables of Aesop (London and New York: Macmillan and Company, 1894), 15-17. Available online at www.pitt-edu/ dash/typeo112.html.

Jones, Samuel (ed.). “To the utmost of her power...” The Enduring Relevance of Octavia Hill. London: Demos, 2012.

Landow, George P. Ruskin. Oxford: Oxford University Press, 1985.

Lees, Andrew. Cities Perceived : Urban Society in European and American Thought, 1820-1940. New York: Columbia University Press, 1985.

Lees, Andrew and Lynn Hollen Lees. Cities and the Making of Modern Europe, 1750-1914. Cambridge: Cambridge University Press, 2007

Liebmann, George W. Six Lost Leaders: Prophets of Civil Society. Lanham, MD:

Lexington Books, 2001.

Loftus, Alex. Everyday Environmentalism: Creating an Urban Political Ecology. Minneapolis: University of Minnesota Press, 2012.

Marsden, Gordon (ed.). Victorian Values: Personalities and Perspectives in NineteenthCentury Society. London: Longman, 1990.

Marsh, Jan. Back to the Land: The Pastoral Impulse in England, from 1880 to 1914.

London \& New York: Quartet Books, 1982.

Meacham, Standish. Regaining Paradise: Englishness and the Early Garden City Movement. Yale University Press, 1999. 
Miller, Mervyn. Raymond Unwin: Garden Cities and Town Planning. Leicester: Leicester University Press, 1992.

Mumford, Lewis. The City in History: Its Origins, its Transformations, and its Prospects. San Diego: Harcourt, 1961.

de Nie, Michael. The Eternal Paddy: Irish Identity in the British Press, 1798-1882. Madison: University of Wisconsin Press, 2004.

O'Brien, D. P. The Classical Economists Revisited. Princeton and Oxford: Princeton University Press, 2004.

Olson, Donald. The City as a Work of Art: London, Paris, Vienna. New Haven and London: Yale University Press, 1986.

Robbins, Paul. Political Ecology: A Critical Introduction. Malden, MA: Blackwell, 2004.

Rose, Derek A. Octavia's People: The story of the Pearce Family at Redcross Cottages. Fakenham, Norfolk: The Lanceni Press, n.d.

Schrepfer, Susan R. Nature's Altars: Mountains, Gender, and American Environmentalism, Lawrence, Kansas: University Press of Kansas, 2005.

Sheppard, Francis. London 1808-1870: The Infernal Wen. Berkeley and Los Angeles: University of California Press, 1971.

Slack, Kathleen. Henrietta's Dream: A Chronicle of Hampstead Garden Suburb. London: n.p. 1982.

Stedman Jones, Gareth. Outcast London: A Study in the Relationship between Classes in Victorian Society. Harmondsworth: Penguin Books, 1971.

Tarn, J. N. Five Per Cent Philanthropy; an Account of Housing in Urban Areas between 1840 and 1914. London: Cambridge University Press, 1973.

Thompson, E. P. Customs in Common. Pontypool: Merlin Press, 1991.

Williams, Raymond. The Country and the City. New York: Oxford University Press, 1973.

Williams, Raymond. Keywords: A Vocabulary of Culture and Society. New York, Oxford University Press, 1976.

Wohl, Anthony S. The Eternal Slum: Housing and Social Policy in Victorian London. Montreal : McGill-Queen's University Press, 1977. 


\section{Secondary Sources: Articles and Chapters}

Boas, George. "Nature." In Dictionary of the History of Ideas, edited by Philip P. Wiener (New York: Charles Scribner's Sons, 1973), III: 346-351.

Bremner, Robert H. "An Iron Scepter Twined with Roses": The Octavia Hill System of Housing Management." Social Service Review 39, no. 2 (1965): 222-31.

Cooper, Timothy. British Environmental History. Article on the Making History site of the University of London's Institute of Historical Research, n. d. (but after 2007).

Available from: http://www.history.ac.uk/makinghistory/resources/articles/ environmental history.html

Cosgrove, Denis E. "John Ruskin and the Geographical Imagination." Geographical Review 69, no. 1 (1979): 43-62.

Cronon, William. “The Uses of Environmental History," Environmental History Review 17:3 (Fall 1993), 1-22

Gaskell, S. Martin. "Gardens for the Working Class: Victorian Practical Pleasure." Victorian Studies 23 (1980): 479-501.

Gordon, S. "The London Economist and the High Tide of Laissez-Faire.” Journal of Political Economy, 63 (6), (1955), 461-488.

Grimsley, Ronald. "Rousseau's Paris" In City and Society in the 18th Century, edited by Paul Fritz and David Williams, 3-18 (Toronto: Hakkert, 1973).

Hetherington, Noriss S. "Isaac Newton's Influence on Adam Smith's Natural Laws in Economics." Journal of the History of Ideas 44:3 (July 1983), 497-505.

Heynen, Nik. "Green urban political ecologies: toward a better understanding of innercity environmental change." Environment and Planning A, 38 (2006): 499-516.

Hunt, John Dixon, "Ruskin: The Design of Nature and the Transcription of Its Manuscript," Assemblage, 32 (Apr., 1997), 12-21.

Kaika, Maria and Erik Swyngedouw, "The Urbanization of Nature: Great Promises, Impasse, and New Beginnings." in , A New Companion to the City, edited by G. Bridge and S. Watson, 567-580. Oxford: Blackwell, 2010.

Miller, Mervyn. "The Saga of the 'Suburb Salubrious'." Planning History 14:3 (1992), 4-12.

Moreau, Gilbert. "L'action d'Octavia Hill en faveur des pauvres et de leur environnement." Revue française de civilisation britannique 12, no. 3 (2003): 49-58.

Morrell, Caroline. "Octavia Hill and women's networks in housing." In Gender, Health and Welfare, edited by Anne Stewart and John Digby, 91-121. London: Routledge, 1996. 
Morris, Susannah. "Changing Perceptions of Philanthropy in the Voluntary Housing Field in London.” In Philanthropy, Patronage and Civil Society: Experiences from Germany, Great Britain, and North America, edited by Thomas Adam, 138-162. Bloomington: Indiana University Press, 2004.

Mumford, Lewis. "The Natural History of Urbanization." In Man's Role in Changing the Face of the Earth, edited by William L. Thomas, Jr., 382-398. Chicago and London: University of Chicago Press, 1956.

Osborn, Matt. Sowing the Field of British Environmental History, H-Net Environment Group discussion paper, 2001. Available from: www.h-net.org/ environ/ historiography/british.htm.

Polasky, Janet. "Transplanting and Rooting Workers in London and Brussels: A Comparative History." The Journal of Modern History 73, No. 3 (September 2001): 528-560

Seaton, Beverly. "Considering the Lilies: Ruskin's Proserpina and Other Victorian Flower Books." Victorian Studies 28 (1985): 255-282.

Siegel, Daniel. "The Failure of Condescension." Victorian Literature and Culture 33, no. 2 (2005): 395-414.

Smith, G. B. "Godwin, George (1813-1888)." Revised by Ruth Richardson and Robert Thorne. Oxford Dictionary of National Biography. Oxford University Press, 2004.

Sörlin, Sverker and Paul Warde. "The Problem of the Problem of Environmental History: A Re-reading of the Field." Environmental History 12, no. 1 (January 2007): 107-130.

Spence, Margaret E. "The Guild of St. George: Ruskin's Attempt to Translate His Ideas into Practice." Bulletin of the John Rylands University Library of Manchester 40, no. 1 (1957): 147-201.

Swyngedouw, Erik. "Impossible 'Sustainability' and the Postpolitical Condition.” In The Sustainable Development Paradox: Urban Political Economy in the United States and Europe, edited by Rob Krueger and David Gibbs, 13-40. New York: Guilford Press, 2007.

Swyngedouw, Erik, and Heynen, Nik. "Urban Political Ecology, Justice and the Politics of Scale." Antipode 35 (5) 898-918. 2003.

Taylor, O. H. "Economics and the Idea of Natural Laws." The Quarterly Journal of Economics, 44:1 (November 1929), 1-39.

Thompson, Victoria. "Telling 'Spatial Stories': Urban Space and Bourgeois Identity in Early Nineteenth-Century Paris." The Journal of Modern History 75 (September 2003), 523-556. 
Thorsheim, Peter. "Green Space and Class in Imperial London." In The Nature of Cities, edited by Andrew C. Isenberg, 24-37. Rochester, N. Y.: University of Rochester Press, 2006.

Thorsheim, Peter. "The Corpse in the Garden: Burial, Health, and the Environment in Nineteenth-Century London.” Environmental History 16:1 (January 2011), 38-68.

Toker, Umut and Toker, Zeyne. "Revisiting Hampstead Garden Suburb: A (Cautionary) Tale of Spatial Determinism," Focus: Journal of the City and Regional Planning Department. 3: 1(2006)

Available at: http://digitalcommons.calpoly.edu/focus/vol3/iss1/11

Williams, Raymond. "Ideas of Nature." In Problems in Materialism and Culture, London: Verso, 1980: 67-85.

Wohl, Anthony S. "Octavia Hill and the Homes of the London Poor," Journal of British Studies 10, no. 2 (May 1971): 105-131. 